\title{
AVALIAÇÃO EXPERIMENTAL DA TRANSFERÊNCIA DE CALOR EM FORNALHA FLAMOTUBULAR UTILIZANDO COMO COMBUSTÍVEL O BIODIESEL E O ÓLEO DIESEL
}

Gustavo Rodrigues de Souza

Dissertação apresentada à Escola de Engenharia de São Carlos da Universidade de São Paulo, como parte dos requisitos para obtenção do título de Mestre em Engenharia Mecânica.

Orientador: Prof. Dr. Antonio Moreira dos Santos

São Carlos 


\section{Dedicatória}

Dedico este trabalho aos meus avós Benedito Zeppone, Maria Cruz Zeppone, Antonio Rodrigues de Souza e Rita Rosa de Souza.

Aos meus pais maravilhosos, Aparecido Rodrigues de Souza e Mariene Zeppone Rodrigues de Souza.

Às minhas queridas irmãs, Cristiane Rodrigues de Souza e Mariangela Rodrigues de Souza.

Ao João Luiz de Carvalho, Matheus Rodrigues Carvalho e Arthur Rodrigues Carvalho pela alegria de tê-los na minha família.

A toda a minha Família Rodrigues \& Zeppone.

A todos os meus fieis amigos que me acompanham, não importando o tempo ou a presença corporal e sim a valiosa amizade.

Ao meu Amor Naiene dos Santos Pimentel pela compreensão, companheirismo e por existir na minha vida, tornando-a muito melhor a cada dia. 


\section{Agradecimentos}

A Deus, que vem me dando muitas graças ao longo da minha vida.

Ao Professor Dr. Antonio Moreira dos Santos por todo o conhecimento transmitido.

Ao $\mathrm{CNPq}$ pela bolsa concedida e pelo financiamento do Projeto $\mathrm{CNPq} \mathrm{n}^{\circ}$ 460283/01-4 que permitiu a realização do trabalho de pesquisa.

Ao Núcleo de Engenharia Térmica e Fluídos - Escola de Engenharia de São Carlos por toda a infra-estrutura e acolhimento.

Ao LADETEL - Laboratório de Desenvolvimento de Tecnologias Limpas pelo fornecimento do biodiesel utilizado.

Aos Professores Dr. Sérgio Rodrigues Fontes, Dr. Josmar Davilson Pagliuso, Dr. Paulo Seleghim Júnior e Dr. Fernando Eduardo Milioli.

A todos os meus professores e amigos da Universidade Federal de Lavras, em especial ao Professor Fábio Moreira da Silva pela confiança, incentivo e contribuição.

Ao Professor e Amigo Délson Luiz Módolo pela imensa ajuda e contribuição ao presente trabalho, e certamente, a futuros trabalhos que viram.

Aos Técnicos Roberto Lourenço, Roberto Prataviera, Theodomiro Fernando Luchesi, Hélio J. D. Trebi, Jorge Nicolau dos Santos, José F. Torres e Donizete Luchesi.

Ao Psicólogo Antônio Frederico Andrade Ferreira.

Aos companheiros (as) de trabalho Francisco, Marcus, Sandro, Lúcio, Sérgio, Cecília, Juliana, Paulo, Graziela, Érica, Luben, Rodrigo, José Antonio, Manoel, Julio, Ivonete, Deuzuita, Paula, Christian, Renato, Anderson, Vitor, Mário e em especial ao Keyll pela ajuda nas horas difíceis da caminhada. 


\section{Resumo}

SOUZA, G.R. (2005). Avaliação experimental da transferência de calor em fornalha flamotubular utilizando como combustível o biodiesel e o óleo diesel. 87p. Dissertação (Mestrado) - Escola de Engenharia de São Carlos, Universidade de São Paulo, São Carlos, 2005.

O trabalho consiste em uma análise experimental comparativa do processo de combustão e de transferência de calor ao longo de uma fornalha flamotubular. Os combustíveis utilizados são o óleo diesel e o biodiesel proveniente de óleo de fritura. Uma outra parcela deste trabalho é investigar os níveis de emissões gasosas no processo de combustão do biodiesel em fornalha flamotubular. Não seria possível realizar esta pesquisa sem uma fornalha flamotubular dotada de câmaras calorimétricas, janelas de observação e extração de gás, e totalmente instrumentada. Assim, foi efetuado em paralelo o projeto e a construção de uma fornalha calorimétrica flamotubular. Os parâmetros utilizados para se analisar os combustíveis na fornalha são: rendimento térmico, taxa de fluxo mássico, temperatura de chama e perda de carga. Observou-se que o óleo diesel apresentou maior taxa de transferência de calor para a maioria das seções expostas à chama. Na região onde o corpo da chama não está presente, a taxa de transferência de calor do biodiesel torna-se ligeiramente superior. Em relação às emissões gasosas observaram-se baixos níveis de poluentes.

Palavras-chave: fornalha, flamotubular, transferência de calor, biodiesel e óleo diesel. 


\section{Abstract}

SOUZA, G.R. (2005). Experimental evaluation of heat transfer in a flame tube furnace using ethyl ester of vegetable oil and diesel oil. 87p. Dissertação (Mestrado) - Escola de Engenharia de São Carlos, Universidade de São Paulo, São Carlos, 2005.

This work consists in a comparative experimental evaluation of the process of combustion and heat transfer along a flame tube furnace. The fuels used are diesel oil and ethyl ester from waste vegetable oil (biodiesel). Another part of this work investigates the percentage of pollutants and emissions of gases in the flame tube furnace. It would not be possible to carry out this research without a flame tube furnace endowed with calorimetric chambers, windows of observation and extraction of gases, and totally instrumented. Thus, the project and the construction of a flame tube calorimetric furnace were done parallel. The parameters used to analyze the fuels in the furnace are: thermal efficiency, mass flow rate, temperature of flame and draught loss. It was observed that diesel oil presented higher heat transfer rate in most parts of the furnace that was near the flame. In the region where the body of flame is not present, the heat transfer rate of biodiesel becomes a little higher. In relation to emission of gases, it was observed low indexes of pollutants.

Keywords: furnace, flame tube, heat transfer, biodiesel and diesel oil. 


\section{Lista de Figuras}

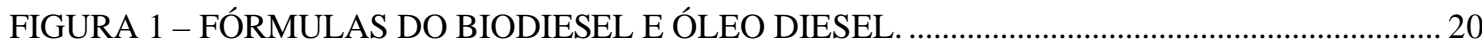

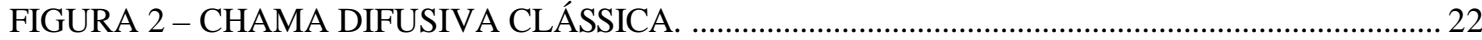

FIGURA 3 - PERFIS DA CONCENTRAÇÃO DE UMA CHAMA DIFUSIVA LAMINAR...................... 22

FIGURA 4 - VARIAÇÃO DO FORMATO DA CHAMA DIFUSIVA COM A VELOCIDADE. ............ 24

FIGURA 5 - EFEITO DO EXCESSO DE AR NA TEMPERATURA DOS PRODUTOS DE COMBUSTÃO E NA TEMPERATURA DO METAL. ……………………………………..... 26 FIGURA 6 - TEMPERATURAS DOS PRODUTOS DE COMBUSTÃO AO LONGO DA FORNALHA.

FIGURA 7 - COMPARAÇÃO ENTRE A EMISSIVIDADE DE CHAMA DO ÓLEO DIESEL E DO

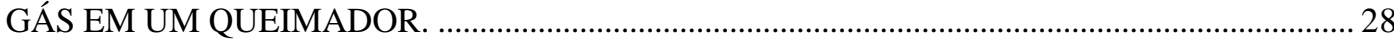

FIGURA 8 - DISTRIBUIÇÃO DO FLU XO DE CALOR E CALOR TRANSFERIDO ACUMULATIVO

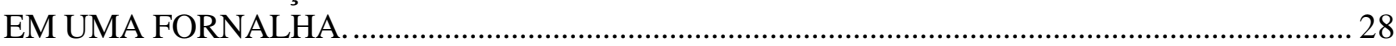

FIGURA 9 - CONDUÇÃO DE CALOR ATRAVÉS DE UMA PLACA. .................................................. 30

FIGURA 10 - TRANSFERÊNCIA DE CALOR POR CONVECÇÃO DE UMA PAREDE PARA UM FLUIDO COM TEMPERATURA INFERIOR.

FIGURA 11 - RELAÇÃO ENTRE O MÍNIMO DIÂMETRO INTERNO DA FORNALHA E O CALOR LÍQUIDO INTRODUZIDO.

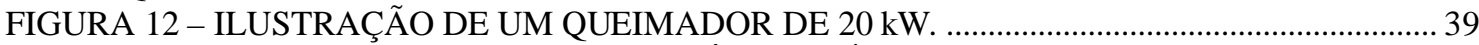

FIGURA 13 - COMPARAÇÃO ENTRE A EFICIÊNCIA TÉRMICA PREVISTA E MEDIDA. ……..... 41

FIGURA 14 - VARIAÇÃO DAS EMISSÕES EM FUNÇÃO DO FATOR DE EXCESSO DE AR (?). 42

FIGURA 15 - DETALHAMENTO CONSTRUTIVO DA FORNALHA. ................................................ 45

FIGURA 16 - DETALHE TRANSVERSAL DA CÂMARA DE ESCOAMENTO DA ÁGUA................ 46

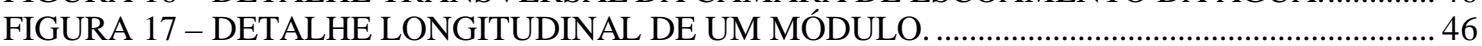

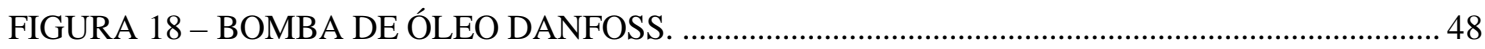

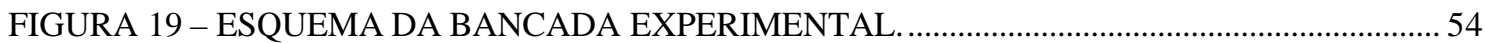

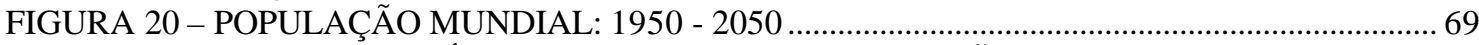

FIGURA 21 - MASSA ESPECÍFICA DOS GASES DA COMBUSTÃO ………………………………........... 77

FIGURA 22 - PERDA DE CARGA NA ENTRADA DOS TUBOS. ......................................................... 80 


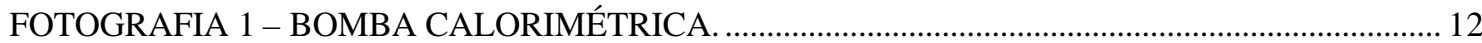

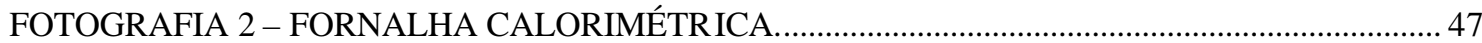

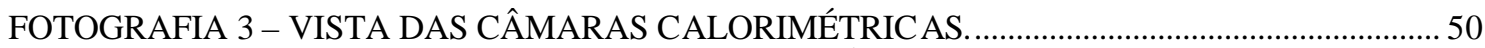

FOTOGRAFIA 4 - SISTEMA DE BOMBEAMENTO DE ÁGUA. ………………………………........ 51

FOTOGRAFIA 5 - SISTEMA DE RESFRIAMENTO EVAPORATIVO DA ÁGUA ARMAZENADA.

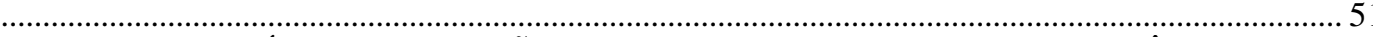

FOTOGRAFIA 6 - DEPÓSITO DE SECÇÃO RETANGULAR COM ESCALA E ROTÂMETRO

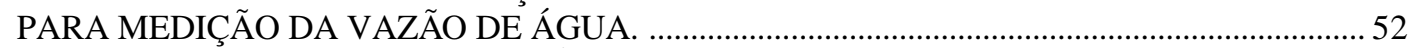

FOTOGRAFIA 7 - LINHA DE COMBUSTÍVEL: BURETA GRADUAD A ………………………….......... 53

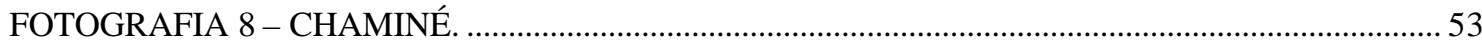

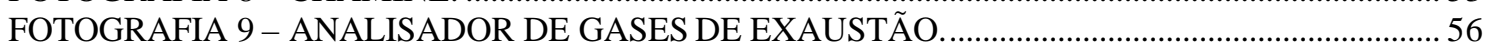

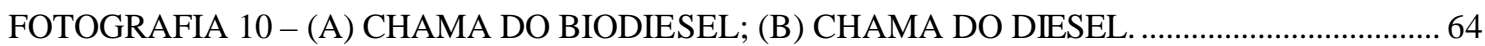


GRÁFICO 1 - VISCOSIDADE DINÂMICA DO ÓLEO DIESEL $\left(26,1^{\circ} \mathrm{C}\right)$ E BIODIESEL $\left(25,6^{\circ} \mathrm{C}\right) . .58$ GRÁFICO 2 - GASES DE EXAUSTÃO OBTIDOS COM A COMBUSTÃO DO ÓLEO DIESEL. .......59 GRÁFICO 3 - GASES DE EXAUSTÃO OBTIDOS COM A COMBUSTÃO DO BIODIESEL. ............. 59 GRÁFICO 4 - TOTAL DE HIDROCARBONETOS (em ppm) NA COMBUSTÃO DO ÓLEO DIESEL E BIODIESEL. 60 GRÁFICO 5 - TAXA DE FLUXO MÁSSICO DOS GASES DE EXAUSTÃO X PRESSÃO DE INJEÇÃO DE COMBUSTÍVEL. 61

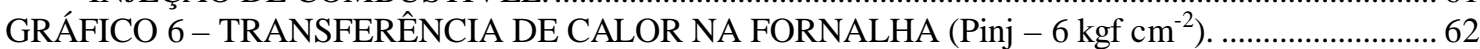

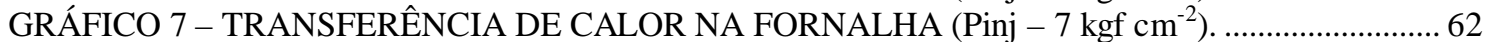

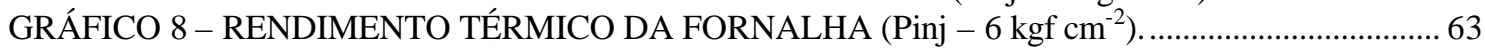
GRÁFICO 9 - RENDIMENTO TÉRMICO DA FORNALHA (Pinj - $\left.7 \mathrm{kgf} \mathrm{cm}^{-2}\right) \ldots \ldots \ldots \ldots \ldots \ldots \ldots \ldots \ldots \ldots \ldots \ldots . . . . . . . . . . . . . . . . . . . .63$

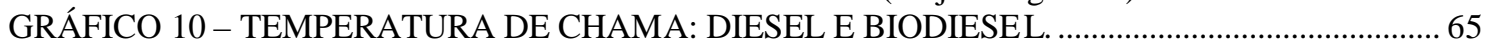
GRÁFICO 11 - RETA E POLINÔMIO DE AJUSTE DA CALIBRAÇÃO DO ROTÂMETRO DE VAZÃO DA ÁGUA. 78 
TABELA 1 - VALORES NORMALMENTE INDICADOS PARA O COEFICIENTE DE EXCESSO DE AR

TABELA 2 - QUALIDADE CARBURANTE DE ALGUNS ÓLEOS COMBUSTÍVEIS.

TABELA 3 - CARACTERÍSTICAS FÍSICO-QUÍMICAS DO ÓLEO DIESEL E DO BIODIESEL DE FRITURAS.

TABELA 4 - CARACTERÍSTICAS: BOMBA DE ÓLEO. ....................................................................... 47

TABELA 5 - CARACTERÍSTICAS DOS COMBUSTÍVEIS: ÓLEO DIESEL E BIODIESEL DE ÓLEO DE FRITURA. 58

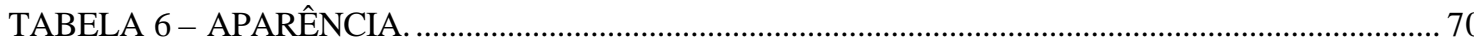

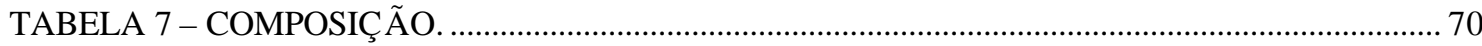

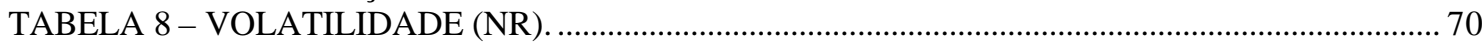

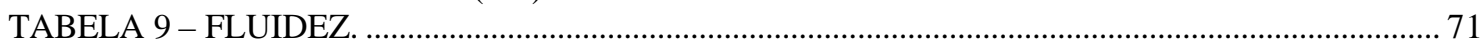

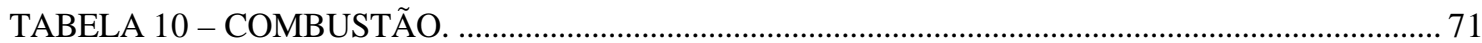

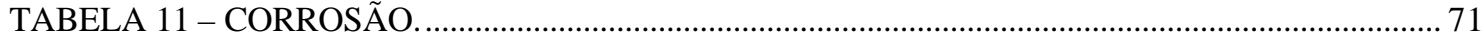

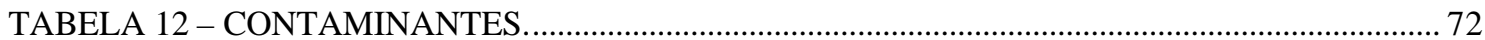

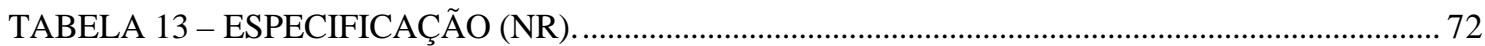

TABELA 14 - PONTO DE ENTUPIMENTO DE FILTRO A FRIO_........................................................ 73

TABELA 15 - ESPECIFICAÇÃO DO CORANTE PARA O ÓLEO DIESEL INTERIOR. ......................74

TABELA 16 - ESPECIFICAÇÃO PRELIMINAR DO BIODIESEL. ........................................................ 75

TABELA 17 - CALIBRAÇÃO DO ROTÂMETRO PARA MEDIÇÃO DA VAZÃO DE ÁGUA. ........ 78

TABELA 18 - PROPRIEDADES DE COMBUSTÍVEIS DIESEL E BIODIESEL.................................. 79

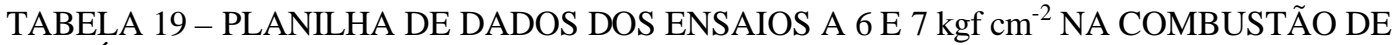
ÓLEO DIESEL. ............................................................................................................. 81

TABELA 20 - PLANILHA DE DADOS DOS ENSAIOS A 6 E $7 \mathrm{kgf} \mathrm{cm}^{-2}$ NA COMBUSTÃO DE

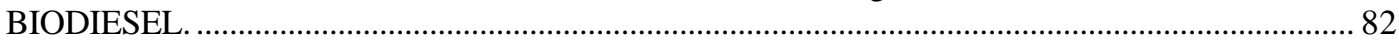




\section{Lista de Símbolos}

ASME - The American Society of Mechanical Engineers

CO - Monóxido de Carbono

$\mathrm{CO}_{2}-$ Dióxido de Carbono

HC-Hidrocarbonetos

$N O$ - Óxido Nítrico

$N O_{x}-$ Óxidos de Nitrogênio

$N u_{m}-$ Número de Nusselt Médio

$\mathrm{O}_{2}-$ Oxigênio

Pr-Número de Prandtl

Re - Número de Reynolds

THC - Total de Hidrocarbonetos 


\section{Sumário}

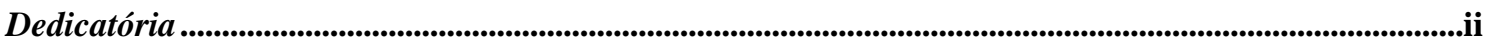

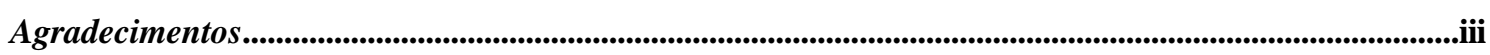

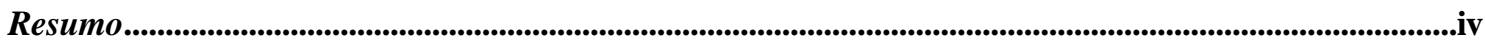

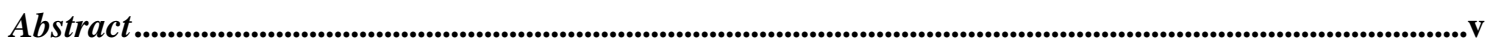

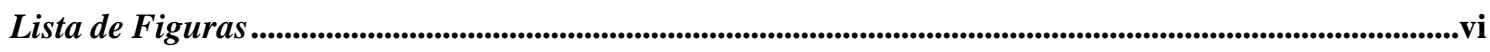

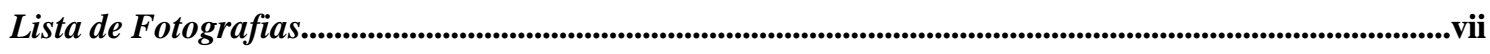

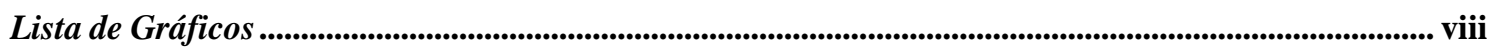

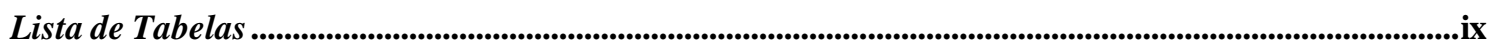

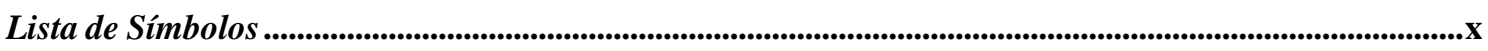

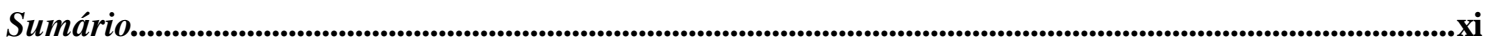

1 - INTRODUÇÃ

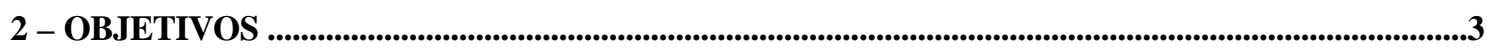

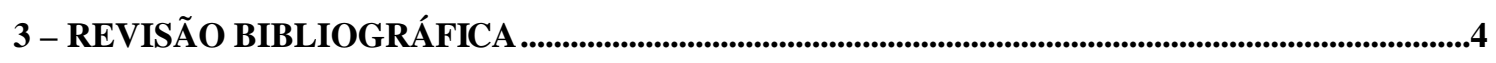

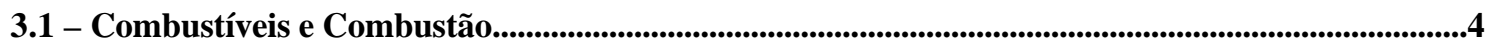

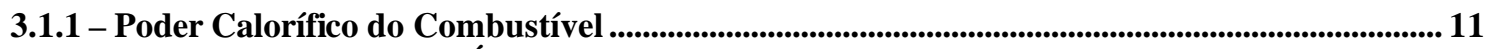

3.1.2 - Combustíveis Fósseis - Óleo Diesel...................................................................................................... 12

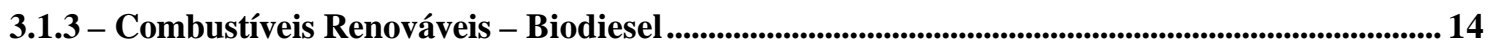

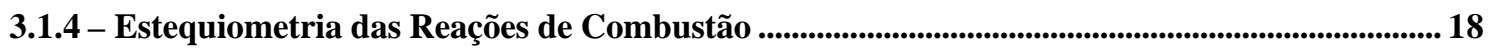

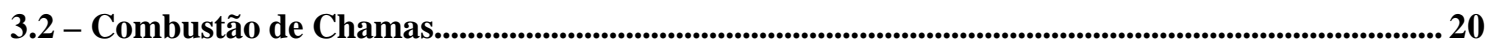

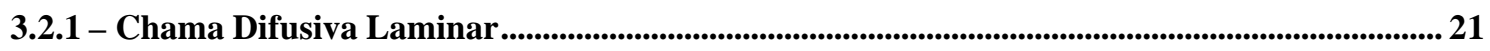

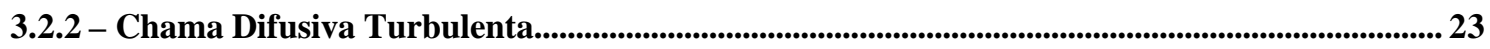

3.2.3 - Temperatura Adiabática de Chama ............................................................................................................. 24

3.3 - Transferência de Calor em Fornalha ............................................................................................................... 29

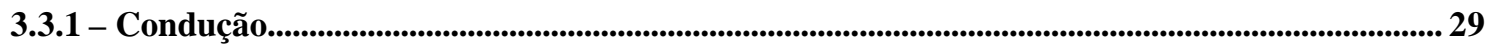

3.3.2 - Conveç̧ão..................................................................................................................................................................... 30

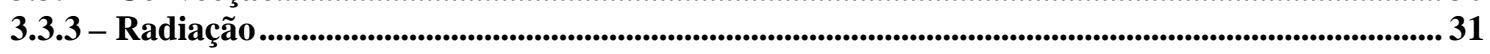

3.3.4 - Avaliação Térmica de uma Célula Calorimétrica ...................................................................33

3.4 - Queimadores de Combustíveis em Fornalhas Flamotubulares .................................................38

3.5 - Gases de Exaustão x Fator de Excesso de Ar.........................................................................................4 41

3.6 - Espessura da parede das Fornalhas para Caldeiras Flamotubulares ................................................ 42

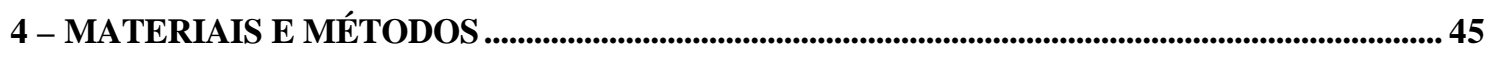

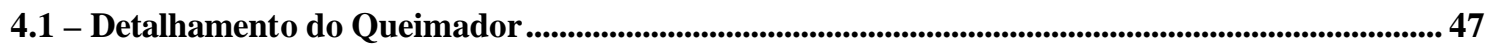

4.2 - Sistema de aquisição de temperaturas com termopar .................................................................49 


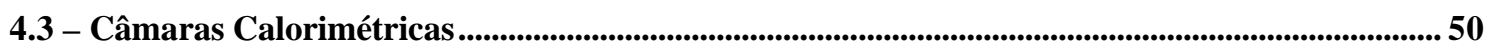

4.4 - Consumo de Combustível.................................................................................................................. 52

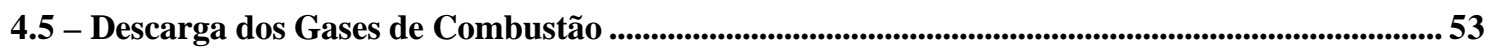

4.6 - Diagrama Esquemático................................................................................................................................................... 54

4.7 - Metodologia utilizada para a variação do Fator de Excesso de Ar.....................................................54

4.8 - Temperatura de Chama ................................................................................................................................................. 55

4.9 - Analisador de Gases................................................................................................................................. 55

4.10 - Caracterização dos Combustíveis........................................................................................................... 56

4.10.1 - Poder Calorífico Superior...................................................................................................................... 56

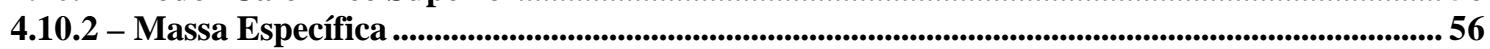

4.10.3 - Viscosidade Dinâmica..................................................................................................................................... 56

4.10.4 - Características dos Combustíveis ............................................................................................................... 58

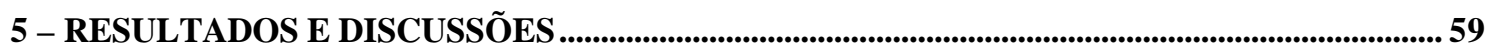

5.1 - Emiss

5.2 - Taxa de Fluxo de Massa ........................................................................................................................................... 60

5.3 - Rendimento Térmico da Fornalha ....................................................................................................... 61

5.4 - Temperatura de Chama .............................................................................................................................. 64

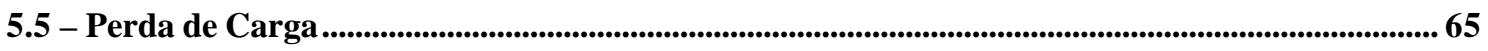

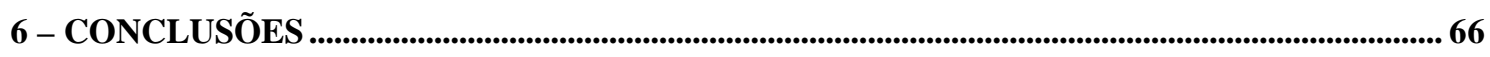

7 - SUGESTÕES PARA TRABALHOS FUTUROS...................................................................... 68

8 - ANEXOS....................................................................................................................................................................... 69

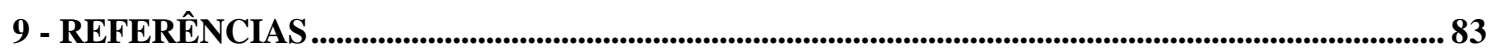




\section{1 - INTRODUÇÃO}

O consumo de energia no mundo em 2003, segundo o Ministério de Minas e Energia (MME), foi de $8 \times 10^{9}$ toneladas equivalentes de petróleo (tep), onde 1 tep corresponde a $10.800 .000 \mathrm{kcal}$. As fontes de petróleo, gás natural e carvão mineral são suficientes para manter este consumo por aproximadamente 43, 65 e 236 anos respectivamente (LORA, 2000).

Conforme a U.S. Census Bureau, em agosto de 2004 éramos 6,39 x 109 habitantes em nosso planeta, e o crescimento populacional pode chegar a um bilhão de pessoas a cada 12 anos. Todo esse aumento da população mundial exerce uma enorme pressão sobre o meio ambiente, como por exemplo: aumento do consumo de água, de alimentos, da necessidade de transporte, do consumo de energia e de outros recursos que afetam diretamente o meio em que vivemos.

A importância da combustão na nossa vida diária pode ser mostrada de várias formas. Por exemplo, a energia gerada diretamente pela combustão de um gás/líquido ou indiretamente através da troca de calor fornecido pela combustão, transferido para a água que se vaporiza.

Atualmente, pesquisa-se muito sobre combustíveis renováveis aplicados a motores de combustão interna. Não podemos negar que toda a comoção, hoje estabelecida na mídia, vem sendo conquistada por pesquisadores empenhados em difundir novos conhecimentos e técnicas de utilização de novos combustíveis, utilizados como alternativas energéticas melhores para o mundo em que vivemos. Mas, não podemos nos esquecer que estes combustíveis devem e podem ser testados em diferentes máquinas térmicas já existentes, ou desenvolvidas para tais objetivos, como por exemplo, as caldeiras flamotubulares e aquatubulares que utilizam este tipo de combustível. Há muito pouco tempo, passamos no Brasil por situações de racionamento de energia elétrica, isto porque nossas matrizes energéticas estão concentradas em poucas fontes. Uma opção para se diversificar estas matrizes seria a construção de um número maior de usinas termo-elétricas.

O presente trabalho torna-se de extrema relevância nos dias atuais, pois envolve comparações entre um combustível de origem fóssil e outro de origem vegetal (fonte renovável de energia), avaliando seus respectivos produtos de combustão. Além disso, coloca-se à prova a eficiência de cada um dos combustíveis no aspecto transferência de calor. 
Segundo El-Mahallawy et al. (2003), existem vários cuidados a serem considerados ao se projetar uma fornalha para uma caldeira flamotubular. Os principais cuidados incluem: limites de estabilidade, alta eficiência de combustão, alta intensidade de calor trocado, altas taxas de transferência de calor da chama, baixa emissão de poluentes e baixos níveis de barulho. 


\section{2 - OBJETIVOS}

O principal objetivo deste trabalho é a investigação comparativa de como ocorre o processo de combustão e de transferência de calor ao longo de uma fornalha flamotubular usando como combustível o óleo diesel e o biodiesel proveniente de óleo de fritura. Faz parte também dos objetivos deste trabalho investigar os níveis de emissões gasosas no processo de combustão do biodiesel em fornalha flamotubular.

Não seria possível atingir estes objetivos sem uma fornalha flamotubular dotada de câmaras calorimétricas, janelas de observação e extração de gás e totalmente instrumentada. Assim, constitui-se em objetivos paralelos o projeto e a construção de uma fornalha calorimétrica flamotubular. 


\section{3 - REVISÃO BIBLIOGRÁFICA}

\section{1 - Combustíveis e Combustão}

Para se produzir trabalho mecânico, através de uma máquina térmica, são necessárias duas fontes de calor, uma a temperatura mais baixa e outra a temperatura mais elevada. Como na natureza isso acontece na maioria das vezes em condições não adequadas, isto é, não próximas umas das outras, é preciso forçar uma dessas condições. Geralmente produz-se a condição de alta temperatura através dos processos de combustão, sendo que o ar atmosférico, bacias hidrográficas e outros, fazem o papel de baixa temperatura no processo.

“Combustível é toda substância química capaz de combinar quimicamente com outra em uma reação exotérmica", (PAGLIUSO, 1984), ou seja, que haja liberação de calor durante a reação. Os combustíveis podem ser classificados de acordo com a fase em que se encontram ao serem manuseados (líquidos, sólidos ou gasosos). Entre estes, os líquidos e os gasosos não possuem uma divisão clara, pois podem ser transformados uns nos outros de acordo com suas temperaturas e pressões. Parâmetros importantes para o manuseio dos combustíveis líquidos e especificações para projetos são: o peso específico, o ponto de fluidez, a viscosidade e o ponto de fulgor, principalmente para projetos de bicos injetores e queimadores.

Segundo Bazzo (1992), todo processo de combustão deve atender a princípios fundamentais que assegurem economia ou eficiência na queima do combustível. Mesmo em condições normais de operação, os processos de combustão não garantem aproveitamento total da energia disponível no combustível. Uma parcela significativa de energia é perdida para o meio ambiente. Essas perdas acontecem através dos gases que saem na chaminé, através das cinzas, através das paredes do equipamento e até pela ocorrência de combustão incompleta.

Para minimizar essas perdas e otimizar a combustão, devem-se considerar os seguintes fatores:

- Suprimento adequado de ar

- Mistura ar/combustível

- Temperaturas compatíveis

- Tempo suficiente de combustão 
O suprimento de ar está intimamente relacionado ao tipo de combustível e ao equipamento de combustão. Em condições ideais de queima, o suprimento de ar depende apenas da composição química do combustível. Entretanto, em condições reais, quantidades complementares são necessárias com a finalidade de proporcionar uma queima adequada.

$\mathrm{O}$ excesso de ar minimiza as perdas por combustão parcial, porém, maiores fluxos de ar implicam em maiores perdas de calor sensível através dos gases de combustão. Portanto, deve-se observar um ponto de equilíbrio que realmente signifique uma menor perda de energia e isso dependerá, fundamentalmente, do tipo de combustível e do agente de combustão.

O turbilhonamento é uma técnica usada na maioria dos equipamentos de combustão, visando formar uma mistura mais homogênea, permitindo uma sensível redução do coeficiente de excesso de ar. Por definição, o coeficiente de excesso de ar é dado por:

$$
\begin{aligned}
\lambda & =\frac{m_{a r}}{m_{a r}} \\
\lambda & =\frac{\operatorname{Var}}{\operatorname{Var}}{ }^{\bullet}
\end{aligned}
$$

Onde, ? é o coeficiente de excesso de ar, $\operatorname{mar}^{\bullet}$ é a massa estequiométrica de ar [ $\mathrm{kg} \mathrm{kg}^{-1}$ combustível], mar é a massa real de ar $\left[\mathrm{kg} \mathrm{kg}^{-1}\right.$ combustível], $\operatorname{Var}^{\bullet}$ é o volume estequiométrico de ar $\left[\mathrm{m}^{3} \mathrm{n} \mathrm{kg}^{-1}\right.$ combustivel $]$ e Var é o volume real de ar $\left[\mathrm{m}^{3} \mathrm{n}\right.$ $\mathrm{kg}^{-1}$ combustível].

Os valores estequiométricos são calculados partindo-se das reações químicas, de acordo com cada tipo de combustível. Para efeito de análise ou de projeto do equipamento, além do ar de combustão, são necessários que também sejam definidos os valores correspondentes aos gases de combustão. Onde, $m g^{\bullet}$ é a massa estequiométrica de gases de combustão [ $\mathrm{kg} \mathrm{kg}^{-1}$ combustível], $m g$ é a massa real de gases de combustão [kg $\mathrm{kg}^{-1}$ combustível], $V g^{\bullet}$ é o volume estequiométrico de gases combustão $\left[\mathrm{m}^{3} \mathrm{n} \mathrm{kg}^{-1}\right.$ combustível] e $V g$ é o volume real de gases de combustão $\left[\mathrm{m}^{3} \mathrm{n} \mathrm{kg}^{-1}\right.$ combustível $]$. 
O tempo de permanência de uma partícula de combustível no interior de uma fornalha deve ser suficiente para garantir queima completa e vai depender do suprimento de ar e da temperatura de combustão. A presença de monóxido de carbono ou de fuligem na chaminé é conseqüência direta de temperaturas baixas, insuficiência de ar ou operação inadequada do equipamento. Em alguns equipamentos, a presença de carbono não queimado no cinzeiro é inevitável em função do próprio processo de queima. Isso pode ser minimizado mediante alimentação adequada do combustível, melhora na mistura ar/combustível ou mesmo realizando-se pequenas alterações no projeto do equipamento. Para caracterização e controle do processo de combustão é fundamental que se conheça a composição química do combustível.

Os combustíveis sólidos e líquidos, de uso mais comum na geração de vapor, têm sua composição química definida em termos de carbono, hidrogênio, enxofre, oxigênio, nitrogênio, umidade e cinzas. Carbono, hidrogênio e enxofre são os elementos que reagem com o oxigênio, liberando energia. Em condições ideais, a queima completa desses elementos deve envolver uma quantidade mínima de oxigênio, calculada a partir das reações químicas de combustão. Partindo da reação química de cada elemento combustível com o oxigênio e considerando que na massa do ar 23,15\% é oxigênio, determina-se a quantidade de ar estequiométrico necessário para a queima de um quilo de qualquer combustível, usando-se a fórmula:

$$
m_{a r} \cdot=138,2\left[\frac{C}{12}+\frac{H}{4}+\frac{S}{32}-\frac{O}{32}\right]
$$

Onde, $m_{a r}$ é a massa de ar estequiométrica para queimar um quilo de combustível, $C$ é o teor de carbono do combustível $\left[\mathrm{kg} \mathrm{kg}^{-1}\right.$ combustível], $H$ é o teor de hidrogênio do combustível [ $\mathrm{kg} \mathrm{kg}^{-1}$ combustível], $S$ é o teor de enxofre do combustível $[\mathrm{kg}$ $\mathrm{kg}^{-1}$ combustível] e $O$ é o teor de oxigênio do combustível $\left[\mathrm{kg} \mathrm{kg}^{-1}\right.$ combustível].

Em termos de volume, o ar tem $21 \%$ de oxigênio. De maneira similar, agora relacionando-se massa molecular de cada elemento combustível com o volume molecular do oxigênio $\left(22,4 \mathrm{~m}^{3} \mathrm{n} \mathrm{kmol}^{-1}\right)$ envolvido nas reações químicas, para combustíveis sólidos e líquidos, o volume estequiométrico de ar pode ser obtido de:

$$
\operatorname{Var}^{\bullet}=106,7\left[\frac{C}{12}+\frac{H}{4}+\frac{S}{32}-\frac{0}{32}\right]
$$


O mesmo procedimento pode ser adotado para calcular a massa ou o volume de gases formados na combustão. Neste sentido, para combustíveis sólidos e líquidos, obtém-se:

$$
\begin{aligned}
& m_{g} \cdot=44\left(\frac{C}{12}\right)+9\left(H+\frac{W}{9}\right)+64\left(\frac{S}{32}\right)+\ldots \ldots . .+0,7685 m_{a r} \cdot \\
& V_{g}^{\bullet}=22,4\left[\frac{C}{12}+\frac{H}{2}+\frac{W}{18}+\frac{S}{32}\right]+\ldots \ldots+0,79 V_{a r} \cdot
\end{aligned}
$$

Onde, $W$ é o teor de umidade do combustível $\left[\mathrm{kg} \mathrm{kg}^{-1}\right.$ combustível].

O nitrogênio presente na composição de alguns tipos de combustíveis, vapor de nebulização, ou a umidade do ar de combustão, representam parcelas menores na conta global. Para casos que requeiram maior precisão nos resultados, tais parcelas devem ser computadas e adicionadas ao volume real dos gases de combustão.

Muitas vezes, a composição química do combustível não é conhecida, exigindo o emprego de outros métodos no cálculo do volume estequiométrico de ar ou de gases de combustão. Valores aproximados podem ser determinados a partir do poder calorífico inferior do combustível, conforme equações definidas a seguir:

Para combustíveis sólidos $\left[\mathrm{m}^{3} \mathrm{n} \mathrm{kg}^{-1}\right]$ :

$$
\begin{aligned}
& \text { Var }{ }^{\bullet}=\left[\frac{1,01}{4186}\right] P C I+0,50 \\
& V^{\bullet}=\left[\frac{0,89}{4186}\right] P C I+1,65
\end{aligned}
$$

Para combustíveis líquidos $\left[\mathrm{m}^{3} \mathrm{n} \mathrm{kg}^{-1}\right]$ :

$$
\begin{aligned}
& \operatorname{Var}^{\bullet}=\left[\frac{0,85}{4186}\right] P C I+2,00 \\
& V^{\bullet}=\left[\frac{1,11}{4186}\right] P C I
\end{aligned}
$$


No caso de gás natural ou gás de coqueira $\left[\mathrm{m}^{3} \mathrm{n} \mathrm{kg}^{-1}\right]$ :

$$
\begin{aligned}
& \operatorname{Var}^{\bullet}=\left[\frac{1,09}{4186}\right] P C I-0,25 \\
& V^{\bullet}=\left[\frac{1,14}{4186}\right] P C I+0,25
\end{aligned}
$$

O poder calorífico inferior é tomado em $\mathrm{kJ} \mathrm{kg}^{-1}$ e todos os resultados são obtidos em $\mathrm{m}^{3} \mathrm{n} \mathrm{kg}^{-1}$, inclusive para combustíveis gasosos. O tipo de combustível e o equipamento envolvido são fatores determinantes do coeficiente de excesso de ar e, portanto, das condições reais de combustão. Nas condições normais de queima, a combustão se processa com excesso de ar, nessas condições tem-se:

$$
\begin{aligned}
& m_{a r}=\lambda \cdot m_{a r} \cdot \\
& V_{a r}=\lambda \cdot V_{a r} \cdot \\
& m_{g}=m_{g} \cdot(\lambda-1) m_{a r} \cdot \\
& V_{g}=V_{g}^{\bullet}+(\lambda-1) V_{a r} \cdot
\end{aligned}
$$

O excesso de ar pode ser ajustado mediante um controle adequado do equipamento. $\mathrm{O}$ cálculo do coeficiente de excesso de ar implica na medição do fluxo real de ar de combustão ou na análise química dos gases de combustão. A medição do fluxo de ar tem o inconveniente de apresentar margens de erro, muitas vezes não toleráveis, tornando os resultados imprecisos. A determinação das porcentagens de $\mathrm{CO}_{2}$ ou de $\mathrm{O}_{2}$ nos gases de combustão é uma alternativa viável para a maioria dos combustíveis normalmente aplicados às caldeiras. Os medidores acusam os percentuais de $\mathrm{CO}_{2}$ e $\mathrm{O}_{2}$ em volume e na base seca.

Assim, considerando-se apenas a parcela de gases secos: 


$$
V_{g s}=V_{g s}^{\bullet}+(\lambda-1) V_{a r}^{\bullet}
$$

Para muitos combustíveis, $V_{g s}{ }^{\bullet}$ é aproximadamente igual a $V_{a r}{ }^{\bullet}$, tem-se:

$$
\lambda=\frac{\% \mathrm{CO}_{2}^{\cdot}}{\% \mathrm{CO}_{2}}
$$

Onde, $\% \mathrm{CO}_{2}{ }^{\bullet}$ é a porcentagem máxima de $\mathrm{CO}_{2}$ em condições de queima ideal e $\% \mathrm{CO}_{2}$ é a porcentagem medida de $\mathrm{CO}_{2}$ na base da chaminé

Para combustíveis sólidos e líquidos:

$$
\begin{aligned}
& V_{g s}^{\bullet}=22,4\left[\frac{C}{12}+\frac{S}{32}\right]+\ldots+0,79 . V_{a r} \cdot \\
& \% \mathrm{CO}_{2}^{\bullet}=\left[\frac{2240}{12}\right] \frac{C}{V_{g s}^{\bullet}}
\end{aligned}
$$

Tabela 1 - Valores normalmente indicados para o Coeficiente de Excesso de Ar.

\begin{tabular}{lcc}
\hline Combustível & Tipo de Queima & Excesso de Ar $(\%)$ \\
\hline Gás Combustível & suspensão & 5 a 20 \\
Carvão Pulverizado & suspensão & 10 a 25 \\
Óleo Combustível & suspensão & 10 a 25 \\
Carvão Granulado & grelha & 30 a 60 \\
Lenha & grelha & 30 a 60 \\
\hline
\end{tabular}

Fonte: Bazzo (1992).

Duas alternativas se apresentam como viáveis na determinação do coeficiente de excesso de ar, levando-se em conta apenas valores medidos na base da chaminé.

Como primeira alternativa, pode-se desconsiderar a diferença existente entre $V_{a r} \cdot$ e $V_{g s}$, analisando-se a relação existente entre o conteúdo volumétrico de $\mathrm{O}_{2}$ e o conteúdo de gases secos na chaminé.

$$
\% O_{2}=21(\lambda-1) \frac{V_{a r}^{\bullet}}{V_{g s}}
$$


Resultando em:

$$
\lambda=\frac{21}{21-\% O_{2}}
$$

Onde, $\% \mathrm{O}_{2}$ é a porcentagem do $\mathrm{O}_{2}$ medida na base da chaminé.

Como segunda alternativa, pode-se relacionar a proporção existente entre o conteúdo volumétrico de $\mathrm{O}_{2}$ e o conteúdo volumétrico de nitrogênio. Enquanto a porcentagem de $\mathrm{O}_{2}$ liberada com os gases de combustão é proporcional apenas ao excesso de ar, a porcentagem de $\mathrm{N}_{2}$ é proporcional a todo o ar comburente.

$$
V_{O 2}=0,21(\lambda-1) V_{a r}^{\bullet}
$$

Pode-se deduzir que:

$$
V_{O 2}=0,21(\lambda-1)\left[\frac{V N_{2}}{0,79 . \lambda}\right]
$$

Onde, para combustíveis isentos de enxofre.

$$
\% \mathrm{~N}_{2}=100-\left(\% \mathrm{CO}_{2}+\% \mathrm{O}_{2}\right)
$$

E finalmente:

$$
\lambda=\frac{100-\% \mathrm{CO}_{2}-\% \mathrm{O}_{2}}{100-\% \mathrm{CO}_{2}-4,76 . O_{2}}
$$

A determinação do coeficiente de excesso de ar pela equação acima, se restringe aos combustíveis que estejam isentos, ou que contenham pouco enxofre e nitrogênio. Também, a presença de umidade nos gases de combustão não é considerada, tendo em vista a medição dos gases $\mathrm{CO}_{2}$ e $\mathrm{O}_{2}$ na base seca. 


\subsection{1 - Poder Calorífico do Combustível}

É obtido pela medida da quantidade de energia transferida de um vaso calorimétrico onde se realiza a combustão de uma certa massa ou volume de uma amostra de combustível, onde o combustível e o ar são introduzidos no calorímetro na condição padrão $\left(1 \mathrm{~atm}, 25^{\circ} \mathrm{C}\right)$ e os produtos de combustão levados à mesma condição padrão.

Ao elevar os produtos de combustão à condição padrão, se a água resultante da combustão estiver na fase líquida, a quantidade de calor transferida do vaso calorimétrico é denominada Poder Calorífico Superior (PCS). Se a água resultante da combustão estiver na fase vapor, a quantidade de calor relativa do calorímetro é denominada Poder Calorífico Inferior (PCI). Logo, quanto maior for a umidade do combustível, menor será o seu PCI.

O Poder Calorífico Inferior pode ser calculado através da seguinte fórmula:

$$
Q_{\text {in }}=Q_{\text {sup }}-Q_{w} \quad\left[k J k^{-1}\right]
$$

Onde: $Q_{w}$ é o calor de condensação do vapor da água nos produtos de combustão, dado de forma geral pela fórmula:

$$
Q_{w}=2500\left(\frac{9 H}{100}+\frac{W}{100}\right)=225 H+25 W \quad\left[k J k^{-1}\right]
$$

Sendo: H e W porcentagens de hidrogênio e de umidade no combustível, e 2500 o calor de condensação de um quilograma do vapor à pressão atmosférica $\left[\mathrm{kJ} \mathrm{kg}^{-1}\right]$.

O Poder Calorífico Superior é determinado experimentalmente em laboratórios usando-se um aparelho chamado calorímetro (ou bomba calorimétrica, fotografia 1). No vaso interno processa-se a queima da amostra do combustível devidamente pesado. A bomba enche-se de oxigênio puro (99,5\%) até uma pressão de 30 bar, e a inflamação da amostra é feita por uma corrente elétrica que incandesce um filamento provocando a ignição de um fio de algodão. A bomba é colocada em um recipiente que contém certa quantidade de água medida no ensaio. No recipiente existe um agitador para criar uma corrente de água facilitando assim a troca de calor entre a bomba e a água ao seu redor. 
Há um termopar especial para medir pequenas variações da temperatura da água no ensaio. O recipiente, por sua vez, tem um invólucro protetor destinado a isolá-lo perfeitamente do meio externo. No calorímetro, mede-se a variação de temperatura da água provocada pela queima completa da amostra do combustível. O calor proveniente da combustão passa através das paredes da bomba e aquece a água. Após algum tempo, estabelece-se um equilíbrio térmico e registra-se a variação da temperatura. Sabendo-se o equilíbrio da água de instalação calcula-se o poder calorífico superior do combustível.

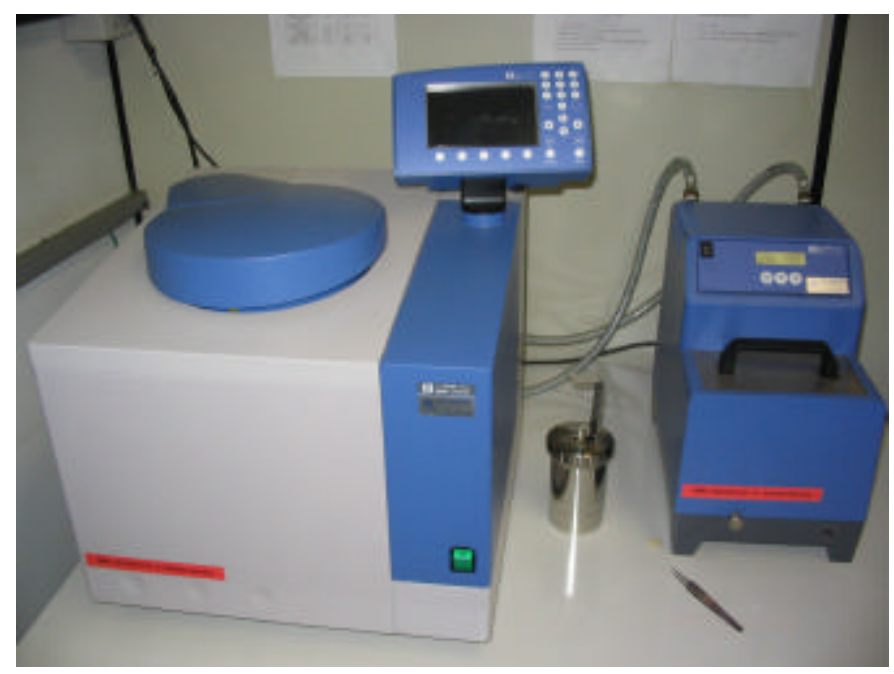

Fotografia 1 - Bomba Calorimétrica.

\subsection{2 - Combustíveis Fósseis - Óleo Diesel}

Os combustíveis fósseis são fontes de energia não renovável. Lora (2000) citando a Organização Latino-Americana de Energia (OLADE, 1995), diz que as reservas de petróleo se extinguirão em cerca de 43,1 anos. Já Campbell e Laherrére ${ }^{1}$ (1998), também citados por Lora (2000), discordam dos resultados apresentados pela OLADE (1995), estimam que a produção atingirá no máximo 40 anos, usando as seguintes justificativas:

- As reservas são determinadas com uma certa probabilidade de erro, além do que, as empresas mascaram os dados por interesses econômicos e políticos;

- A produção de petróleo não se mantém constante;

- E a produção de petróleo atinge seu máximo quando extraída aproximadamente a metade do petróleo e logo cai a zero gradativamente.

${ }^{1}$ CAMPBELl, C. J.; LAHERRÉRE, J. H. The end of cheap oil. Scientific American. March, pp. 60-65, 1998. 
Além da preocupação com o possível esgotamento das fontes de energia, devese questionar o quanto a atmosfera terrestre ainda conseguirá suportar, considerando-se os poluentes que nela estão sendo despejados. Todos os gases que vêm da combustão vão para a atmosfera e os problemas maiores estão nas grandes cidades, principalmente aquelas localizadas em países em desenvolvimento. Segundo a avaliação do GEMS (Sistema Global de Monitoramento Ambiental), citado por Lora (2000), mais de 1,3 x $10^{9}$ pessoas moram em cidades nas quais os níveis de concentração de particulados excede os padrões estabelecidos pela OMS (Organização Mundial da Saúde). Podem-se classificar as emissões de poluentes atmosféricos da seguinte forma:

- Antropogênicas: provocadas pela ação do homem;

- Naturais: causadas por processos naturais, tais como emissões vulcânicas, processos microbiológicos, etc.

Por outro lado, os poluentes podem ser classificados como:

- Primários: aqueles lançados diretamente na atmosfera;

- Secundários: produto de reações fotoquímicas, que ocorrem entre os poluentes primários na atmosfera.

Para o controle da poluição os seguintes aspectos devem ser considerados: padrões de emissões; padrões de qualidade do ar; impostos por emissões de poluentes e análise custo/benefício.

O controle da poluição atendendo aos padrões de emissões é relativamente fácil, pois a coleta de amostras e a análise de composição são feitas em cada ponto de emissão. Adotar padrões de qualidade do ar também é um método eficiente e tem boa viabilidade econômica, a dificuldade está em estabelecer quais os pontos responsáveis pela maior quantidade de emissões. Os impostos por emissões de poluentes consistem em taxas por toneladas de certos tipos de poluentes, isso obrigaria os "poluidores" a se adequarem às exigências ambientais. $\mathrm{O}$ método custo/benefício considera a diminuição dos custos por danos causados pela poluição ambiental com o incremento dos custos de controle da mesma.

O óleo diesel é um combustível de composição complexa, constituído basicamente por hidrocarbonetos parafínicos, olefínicos e aromáticos e, em menor quantidade, por substâncias cuja fórmula química contém átomos de enxofre, nitrogênio, metais, oxigênio, etc. Estes hidrocarbonetos são formados por moléculas constituídas de 8 a 40 átomos de carbono, normalmente sendo mais pesados do que 
aqueles que compõe a gasolina. O óleo diesel é uma fração destilada do petróleo e está localizado entre o querosene e os óleos lubrificantes (por razão de suas características), e os elementos que estão presentes na sua composição são: carbono (86,3\%); hidrogênio $(12,8 \%)$ e enxofre $(0,9 \%)$. Uma das vantagens de se usar o óleo diesel num país como o Brasil é que seu ponto de fluidez é de $-12{ }^{\circ} \mathrm{C}$, e isto dispensa o seu pré-aquecimento no momento em que for manuseado.

O óleo diesel é formulado através da mistura de diversas correntes como gasóleos, nafta pesada, diesel leve e diesel pesado, provenientes das diversas etapas de processamento do petróleo bruto. A Petrobrás produz o Óleo Diesel tipo B, Óleo Diesel tipo D e o Óleo Diesel Marítimo, os quais são entregues diretamente às Companhias Distribuidoras.

As especificações do óleo diesel tipo B e D estão definidas pela Agência Nacional de Petróleo através da Portaria ANP n. 310 de 27/12/2001 e Regulamento Técnico ANP n. ${ }^{\circ}$ 06/2001 (ver Anexo II).

\subsection{3 - Combustíveis Renováveis - Biodiesel}

Os combustíveis de origem vegetal são uma alternativa para a diminuição do consumo de combustíveis fósseis. "Entre os diversos produtos naturais fixadores da energia solar, os glicerídeos, ou óleos vegetais, constituem a fonte renovável mais promissora à obtenção de combustíveis líquidos", (MIC-STI, 1985). Embora as estimativas de custos de produção de óleo vegetal não sejam tão animadoras nos casos das culturas anuais, não há duvida de que para culturas perenes este custo seja menor que os custos de extração de petróleo. Outro enfoque importante é a aplicação integral dos subprodutos adquiridos nas diversas fases dos processos industriais de obtenção da matéria-prima oleaginosa. Estes subprodutos podem ser usados tanto para ração animal, indústrias farmacêuticas, quanto para uso direto em caldeiras. Além disso, os combustíveis renováveis podem substituir parcial ou totalmente as frações mais leves do petróleo (a gasolina, o óleo diesel) e ao mesmo tempo traz benefícios sociais como o aumento de empregos, hoje um dos grandes problemas nacionais. 
A definição adotada pelo Programa Brasileiro de Biocombustíveis ${ }^{2}$ (2002, apud MEIRELLES, 2004), conceitua o Biodiesel como: "Combustível obtido a partir de misturas, em diferentes proporções, de diesel e éster de óleos vegetais".

Tecnicamente, o biodiesel é definido como um éster alquílico de ácidos graxos, obtidos da reação de transesterificação de qualquer triglicerídeo (óleos e gorduras vegetais ou animais) com álcool de cadeia curta (metanol ou etanol). A transesterificação consiste em uma reação química de um óleo vegetal com um álcool, que pode ser etanol ou metanol, na presença de um catalisador ácido $(\mathrm{HCl}$ - ácido clorídrico) ou básico ( $\mathrm{NaOH}$ - hidróxido de sódio ou $\mathrm{KOH}$ - hidróxido de potássio). Como resultado, obtém-se o éster metílico ou etílico (biodiesel), conforme o álcool utilizado, e a glicerina. Portanto, a transesterificação nada mais é que a separação da glicerina do óleo vegetal.

Entre as principais propriedades físico-químicas dos ésteres, o índice de cetano, cujos valores excedem aos do óleo diesel, a viscosidade bastante favorável, a ausência de enxofre e o poder calorífico representam características que determinam a excepcional qualidade carburante dos óleos transesterificados (MIC-STI, 1985).

Tabela 2 - Qualidade carburante de alguns Óleos Combustíveis.

\begin{tabular}{|c|c|c|c|c|c|c|}
\hline Características & Pequi & Algodão & $\begin{array}{c}\text { Pequi } \\
\text { Etanolisado }\end{array}$ & $\begin{array}{c}\text { Algodão } \\
\text { Etanolisado }\end{array}$ & $\begin{array}{c}\text { Babaçu } \\
\text { Etanolisado }\end{array}$ & $\begin{array}{c}\text { Óleo } \\
\text { Diesel }\end{array}$ \\
\hline $\begin{array}{l}\text { Visc. cinemática a } \\
37,8^{\circ} \mathrm{C}(\mathrm{cSt})\end{array}$ & 47,0 & 36,0 & 5,2 & 6,0 & 3,9 & $2-5,4$ \\
\hline $\begin{array}{l}\text { Índice } \\
\text { de cetano }\end{array}$ & 38,0 & 30,0 & 60,0 & 57,5 & 65,0 & $40-48$ \\
\hline $\begin{array}{l}\text { Teor de } \\
\text { enxofre }(\%)\end{array}$ & $<0,01$ & $<0,01$ & $<0,01$ & $<0,01$ & $<0,01$ & $\begin{array}{c}1,3 \\
\text { (máx.) }\end{array}$ \\
\hline $\begin{array}{l}\text { Poder calorífico } \\
\text { superior }(\mathrm{kJ} / \mathrm{kg})\end{array}$ & 39063 & 39272 & 40151 & 39858 & 39523 & 42391 \\
\hline
\end{tabular}

Fonte: Ministério da Indústria e Comércio - Secretaria de Tecnologia Industrial (1985).

Analisando os resultados contidos na tabela (2), segundo CETEC/FIAT ${ }^{3}$ (1983 apud MIC-STI, 1985), percebe-se que os valores de viscosidade para os diversos ésteres são bastante inferiores aos dos óleos vegetais de origem e variam em faixas próximas a do óleo diesel, e os índices de cetano são bem significativos para as misturas transesterificadas. Por outro lado, o poder calorífico superior pouco difere entre eles.

\footnotetext{
${ }^{2}$ Programa Brasileiro de Biocombustíveis - Portaria MCT-702, 2002.

${ }^{3}$ PENIDO FILHO, P.; MARTINS H. Relatório Técnico Interno. Centro Tecnológico de Minas Gerais e FIAT Automóveis/Betim - CETEC/FIAT. 1983.
} 
A nomenclatura utilizada para identificar a porcentagem de biodiesel é definida por $\mathrm{BX}$, onde o X indica a porcentagem de biodiesel em relação à mistura total. Assim, $\mathrm{B} 50$ e B100, correspondem respectivamente às misturas de diesel e biodiesel com 50\% e $100 \%$ de biodiesel.

O biodiesel oferece diversas vantagens sociais, econômicas e ambientais:

- A produção dos insumos para a produção do biodiesel gera empregos diretos;

- O uso do biodiesel como combustível substitui importações de petróleo e diesel;

- $\mathrm{O}$ ciclo do $\mathrm{CO}_{2}$ nos processos que envolvem a produção vegetal, a produção industrial e a combustão nos veículos evita a concentração deste gás na atmosfera, reduzindo o efeito estufa;

- A emissão de poluentes atmosféricos pela queima do biodiesel em motores ICO acontece em proporções inferiores à emissão do óleo diesel.

Os críticos ao uso do biodiesel apontam a necessidade de discutir com maior profundidade as seguintes questões:

- O domínio da técnica de transesterificação com etanol e a qualidade do biodiesel;

- O preço dos óleos vegetais, commodities de exportação, que devem ser pesados em relação à opção do combustível produzido em larga escala;

- Os efeitos do uso do biodiesel sobre os sistemas e peças dos motores de combustão interna;

- A expansão da fronteira agrícola sobre as florestas e matas nativas, uma realidade, apesar dos potenciais ganhos de eficiência;

- O destino a dar ao excedente do subproduto glicerina.

O Biodiesel no Brasil é regulamentado pela portaria ANP No 255 de 15/09/2003. Para os efeitos desta Portaria, o biodiesel é definido como um combustível composto de mono-alquilésteres de ácidos graxos de cadeia longa, derivados de óleos vegetais ou de gorduras animais e designado B100. A especificação preliminar do Biodiesel foi estabelecida pelo Regulamento Técnico ANP Nº 2/2003 (ver Anexo III). 


\subsubsection{1 - Biodiesel de Óleo usado em Frituras}

$\mathrm{Nye}^{4}$ et al. (1983 apud COSTA NETO et al., 2000), realizaram uma análise sobre a reação de transesterificação de óleos de frituras com metanol, etanol, npropanol, iso-propanol, n-butanol, e 2-etoxietanol em meios ácido e básico. O maior rendimento foi obtido com o metanol em meio alcalino, utilizando hidróxido de potássio como catalisador. Nesse mesmo estudo, alguns dos ésteres de menor viscosidade foram selecionados para testes em motores do ciclo diesel. O éster metílico obtido em meio básico, e os ésteres etílico e butílico obtidos em meio ácido, não apresentaram problemas de ignição e desempenho, apresentando pouca ou nenhuma fumaça na exaustão.

Segundo Mittelbach e Tritthart $^{5}$ (1988 apud COSTA NETO et al., 2000), a utilização de biodiesel de óleos de fritura em motores do ciclo diesel apresentou bons resultados. Os testes foram realizados em bancadas dinamométricas e em veículos de carga média com motor turbinado a diesel. A tabela (3) mostra algumas das características físico-químicas do biodiesel usado nesses testes. Apesar de não atender a uma especificação definida, o biodiesel de óleos de frituras apresentou características bastante semelhantes aos ésteres de óleos "novos" descrito no trabalho citado. Mesmo sendo um biodiesel de óleo parcialmente oxidado, suas características foram bastante próximas às do óleo diesel convencional, apresentando inclusive uma boa homogeneidade mediante análise de sua curva de destilação.

\footnotetext{
${ }^{4}$ NYE, M. J. T. W.; WILliAMSON, S.; DESHPANDE, J. H. J. Am. Oil Chem. Soc. 1983, 60, 1598.

${ }^{5}$ MitTElBACH, M.; TRITTHART, P. J. Am. Oil Chem. Soc. 1988, 65, 1185.
} 
Tabela 3 - Características físico-químicas do óleo diesel e do biodiesel de frituras.

\begin{tabular}{lcc}
\hline Características & Óleo Diesel $^{*}$ & Biodiesel \\
\hline Densidade $15^{\circ} \mathrm{C}\left(\mathrm{kg} / \mathrm{m}^{3}\right)$ & 0,849 & 0,888 \\
Ponto inicial de destilação $\left({ }^{\circ} \mathrm{C}\right)$ & 189 & 307 \\
$10 \%$ & 220 & 319 \\
$20 \%$ & 234 & 328 \\
$50 \%$ & 263 & 333 \\
$70 \%$ & 286 & 335 \\
$80 \%$ & 299 & 337 \\
$90 \%$ & 317 & 340 \\
Ponto final de destilação $\left({ }^{\circ} \mathrm{C}\right)$ & 349 & 342 \\
Aromáticos $(\%$, v/v) & 31,5 & $\mathrm{nd}$ \\
Carbono $(\%)$ & 86,0 & 77,4 \\
Hidrogênio $(\%)$ & 13,4 & 12,0 \\
Oxigênio $(\%)$ & 0,0 & 11,2 \\
Enxofre $(\%)$ & 0,3 & 0,03 \\
Índice de cetano & 46,1 & 44,6 \\
Número de cetano & 46,2 & 50,8 \\
Valor calórico inferior $(\mathrm{MJ} / \mathrm{kg})$ & 42,30 & 37,50 \\
\hline Óleo diesel com especificações para combustível do tipo US-2D \\
\multicolumn{2}{c}{ Fonte: Costa Neto et al. (2000). }
\end{tabular}

Apesar dos bons resultados obtidos por esses e outros autores, é preciso ressaltar que o óleo de fritura traz consigo muitas impurezas, oriundas do próprio processo de cocção de alimentos. Portanto, para minimizar este problema, é sempre aconselhável realizar uma pré-filtragem e secagem dos óleos antes da reação de transesterificação.

\subsection{4 - Estequiometria das Reações de Combustão}

“Nas reações de combustão, a rápida oxidação dos elementos combustíveis do combustível resulta em uma liberação de energia à medida que os produtos de combustão são formados", (MORAN; SHAPIRO, 2002). Numa reação química, as moléculas dos reagentes são quebradas e se reorganizam formando os produtos. Os processos de combustão são atingidos basicamente através oxidação dos elementos constituintes dos combustíveis, por isso podem ser representados por uma equação química. A massa de cada elemento permanece constante durante a reação, sendo assim, torna-se simples a obtenção da quantidade de cada constituinte aplicando-se a conservação da massa para cada um deles. A reação de combustão do diesel (composição média $\mathrm{C}_{13} \mathrm{H}_{28}$ ), segundo Holmer ${ }^{6}$ et al. (1980 apud FEITOSA, 2003), com o oxigênio será mostrada a seguir:

\footnotetext{
${ }^{6}$ HOLMER, E.; BERG, P. S.; BERTILSSON, B. I. The utilization of alternative fuels in a diesel engine using different methods. Society of Automotive Engineers - SAE. paper 800544.
} 
Equação de combustão não balanceada:

$$
\begin{gathered}
\mathrm{C}_{13} \mathrm{H}_{28}+\mathrm{O}_{2} \rightarrow \mathrm{CO}_{2}+\mathrm{H}_{2} \mathrm{O} \\
\text { Reagentes Produtos }
\end{gathered}
$$

Fazendo o balanceamento de equação, tem-se:

$$
\mathrm{C}_{13} \mathrm{H}_{28}+a \mathrm{O}_{2} \rightarrow b \mathrm{CO}_{2}+c \mathrm{H}_{2} \mathrm{O}
$$

Resolvendo-se um sistema de três equações e três incógnitas tem-se a equação balanceada:

$$
\mathrm{C}_{13} \mathrm{H}_{28}+20 \mathrm{O}_{2} \rightarrow 13 \mathrm{CO}_{2}+14 \mathrm{H}_{2} \mathrm{O}
$$

A combustão com oxigênio puro justifica-se somente em casos especiais como soldagem, onde se necessita de altíssima temperatura para fusão do material. Na maioria dos processos a combustão é feita com ar atmosférico. Moran e Shapiro (2002) afirmam que o modelo mais simples de combustão admite que o ar na base volumétrica é composto por $21 \%$ de $\mathrm{O}_{2}$ e $79 \%$ de $\mathrm{N}_{2}$. Considerando que a razão molar entre o nitrogênio e o oxigênio seja: $0,79 / 0,21=3,76$, logo, 3,76 moles de nitrogênio acompanham cada mol de oxigênio. Assim tem-se:

$$
\mathrm{C}_{13} \mathrm{H}_{28}+a\left(\mathrm{O}_{2}+3,76 \mathrm{~N}_{2}\right) \rightarrow b \mathrm{CO}_{2}+c \mathrm{H}_{2} \mathrm{O}+d \mathrm{~N}_{2}
$$

Logo, a reação estequiométrica, balanceada, do diesel com o ar é representada por:

$$
\mathrm{C}_{13} \mathrm{H}_{28}+2 \mathrm{O}\left(\mathrm{O}_{2}+3,76 \mathrm{~N}_{2}\right) \rightarrow 13 \mathrm{CO}_{2}+14 \mathrm{H}_{2} \mathrm{O}+75,2 \mathrm{~N}_{2}
$$

Segundo Santos (2003), a reação estequiométrica (ar-teórico), envolve uma mínima quantidade de ar, que fornece a quantidade de oxigênio suficiente para a completa queima dos elementos químicos contidos em um quilograma de combustível. 
Para o combustível diesel, esta razão estequiométrica de ar-teórico é aproximadamente 14,92 kg de ar para $1 \mathrm{~kg}$ de combustível.

Realizando-se a mesma análise para uma molécula típica de éster etílico (biodiesel), que segundo Itokazu (2004) tem sua fórmula representada por $\mathrm{C}_{13} \mathrm{H}_{25} \mathrm{CO}_{2} \mathrm{C}_{2} \mathrm{H}_{5}$ (ver figura 1), obtemos a razão ar/combustível estequiométrica de aproximadamente $12,16 \mathrm{~kg}$ de ar-teórico para queimar $1 \mathrm{~kg}$ de combustível.

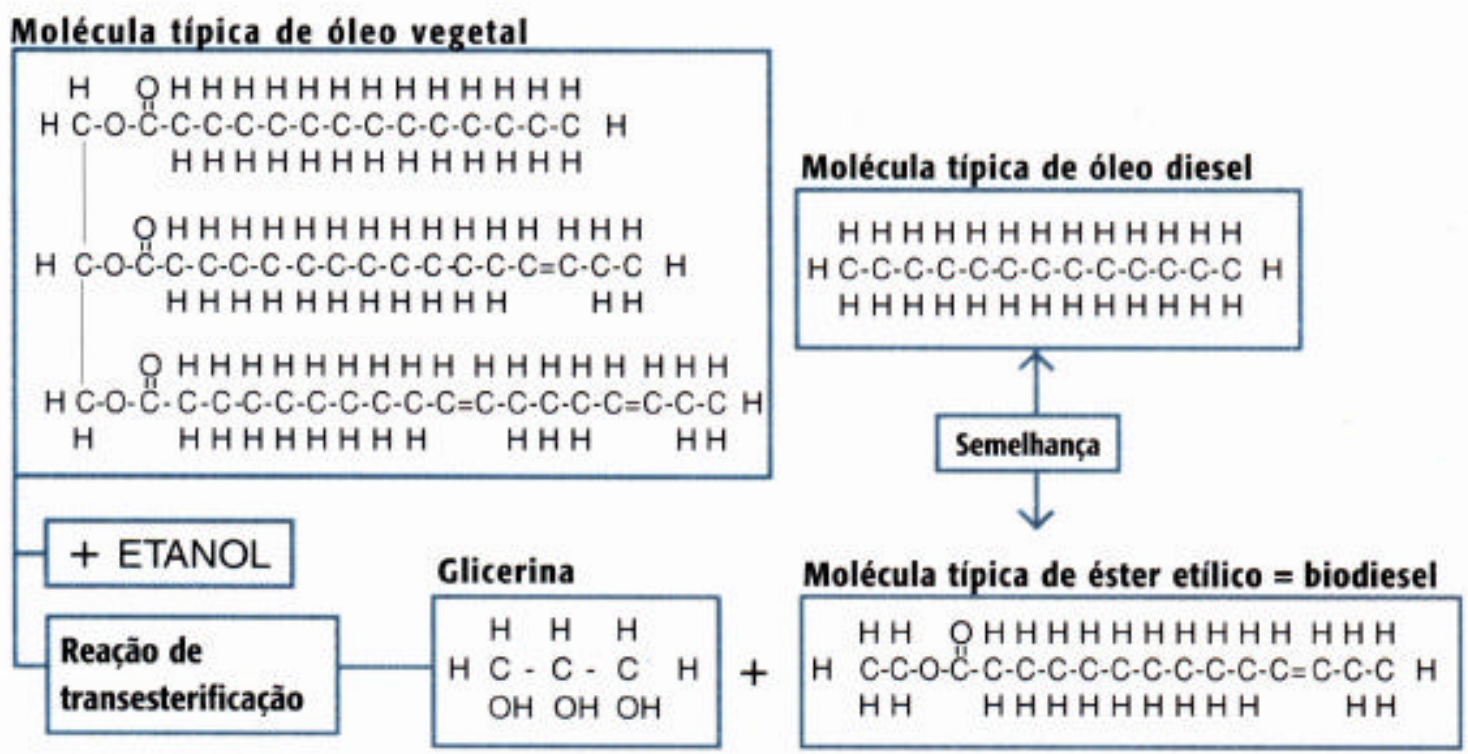

Figura 1 - Fórmulas do Biodiesel e Óleo Diesel.

Fonte: Anfavea/Mercedes-Benz do Brasil (1981, apud Itokazu 2004).

\section{2 - Combustão de Chamas}

A chama representa a propagação auto-sustentada da zona de combustão onde a reação química entre o combustível e o oxidante ocorre (STAMBULEANU ${ }^{7}, 1976$ apud RANGEL, 2003). Os tipos de chamas dividem-se em pré-misturadas e difusivas, parcialmente pré-misturadas ou não, de acordo com o modo como é feita a mistura. Nas chamas pré-misturadas, o combustível e o oxidante são misturados em nível molecular antes de reagirem quimicamente, como é o caso dos motores de ignição. Já nas chamas difusivas, os reagentes estão inicialmente separados e a reação ocorre somente no momento da mistura. Em chamas difusivas parcialmente pré-misturadas, uma pequena quantidade de ar é pré-misturada com o combustível antes da sua injeção na zona de combustão.

\footnotetext{
${ }^{7}$ StAmbUleanU, A. Flame Combustion Processes in Industry. Abacus Press, 1976.
} 
O termo "difusão" é utilizado para denominar a difusão molecular de espécies químicas. Neste caso, entende-se que as moléculas de combustível na chama movem-se em direção às moléculas do oxidante, que estão no sentido contrário. Por definição, a chama difusiva é a chama que não provém de uma pré-mistura e é geralmente usada em fornalhas industriais, onde o oxidante e o combustível alimentam a chama separadamente, como é o caso do presente trabalho de dissertação, impedindo o perigoso fenômeno de retração de chama para dentro do queimador (flash-back) típico de queimadores que operam com chamas pré-misturadas.

\subsection{1 - Chama Difusiva Laminar}

Um exemplo clássico de chama difusiva laminar foi primeiramente estudado por Burke e Schumann ${ }^{8}$ (1928, apud KUO, 1986), constituído por um sistema no qual o fluxo de ar e o fluxo de combustível têm a mesma velocidade de fluxo linear em um tubo circular (figura 2), e o combustível flui lentamente em fluxo laminar ao longo do eixo da chama, onde radialmente se difunde no sentido do oxidante, que está na parte externa. A superfície da chama é definida como o espaço onde o combustível e o oxidante se encontram em proporções estequiométricas.

A figura indica dois tipos de chama: a primeira, super-ventilada com o formato cônico e seus limites convergindo na direção do fluxo através de um eixo de dois tubos concêntricos; a segunda chama, sub-ventilada está representada através de um cone invertido e seus extremos posicionados no sentido da linha do tubo queimador para as paredes do duto.

Observando em uma seção reta em um corte longitudinal através de uma chama laminar nota-se que o combustível atinge suas concentrações máximas no eixo central e sofre uma brusca redução em suas fronteiras. A concentração de $\mathrm{O}_{2}$ diminui quando está próxima à zona de chama e chega a quase zero no seu limite ( $d$ é o diâmetro da chama). As concentrações dos produtos da combustão atingem seus valores máximos ao redor da chama, onde a maioria das reações ocorre, a partir daí, são reduzidas em relação ao eixo central da chama e à atmosfera ao redor (figura 3).

\footnotetext{
${ }^{8}$ BURKE S. P.; SHUMANN T. E. W. Diffusion Flame. Indust. Eng. Chem., Vol. 20, No. 10, p. 998, 1928.
} 


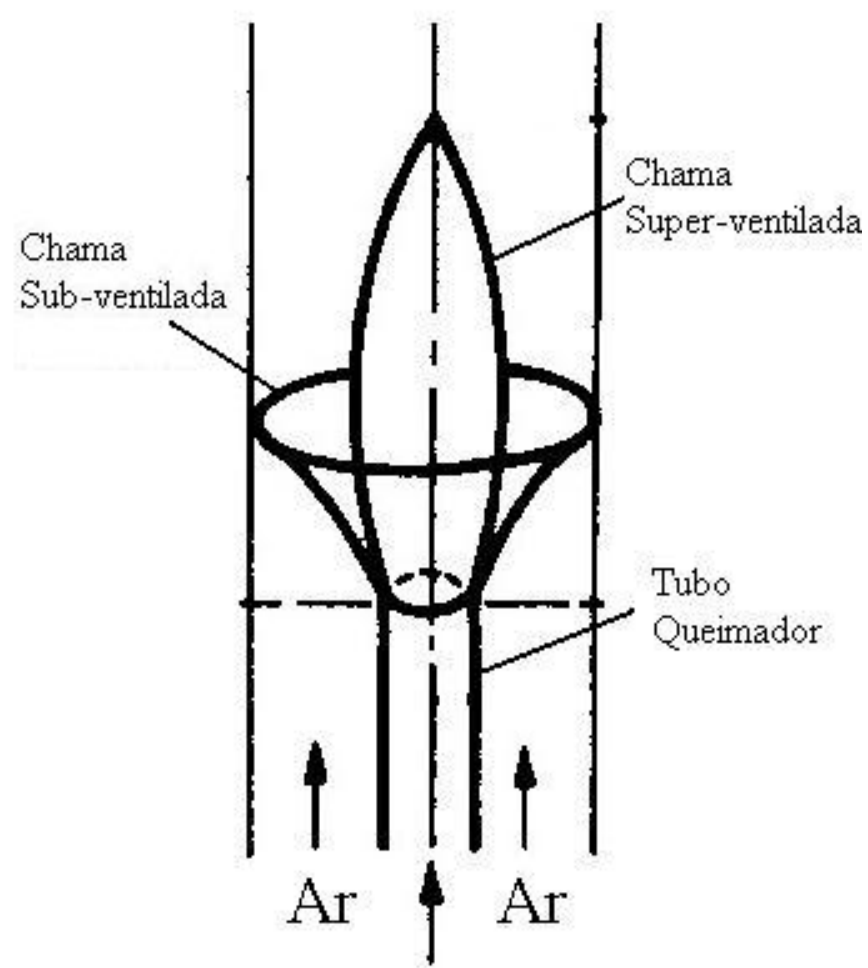

Combustível

Figura 2 - Chama difusiva clássica.

Fonte: Kuo (1986).

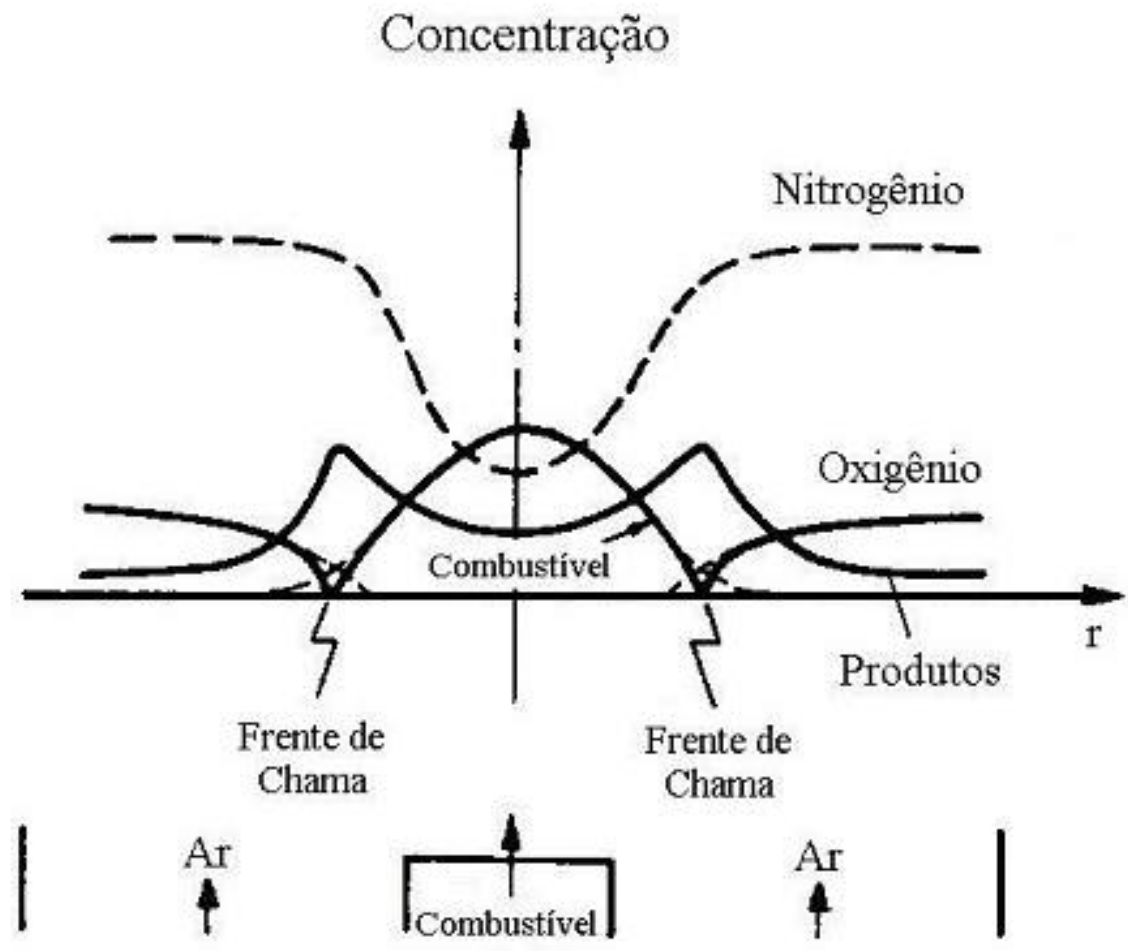

Figura 3 - Perfis da concentração de uma chama difusiva laminar.

Fonte: Kuo (1986). 


\subsection{2 - Chama Difusiva Turbulenta}

As chamas difusivas turbulentas são empregadas na maioria dos sistemas práticos de combustão (TURNS ${ }^{9}, 1996$ apud RANGEL, 2003). A natureza das chamas depende do modelo do fluxo de combustível, que pode ser caracterizado por um parâmetro adimensional conhecido como número de Reynolds $(R e)$.

$$
R e=\frac{\text { Forças Inerciais }}{\text { Forças Viscosas }}=\frac{u \cdot d \cdot \rho}{\mu}
$$

Onde, $u$ é a velocidade do fluido [ $\left.\mathrm{m} \mathrm{s}^{-1}\right], d$ é o diâmetro do duto [m], ? é a densidade do combustível $\left[\mathrm{kg} \mathrm{m}^{-3}\right]$, e $\mu$ é a viscosidade cinemática da gás $\left[\mathrm{kg} \mathrm{m}^{-1} \mathrm{~s}^{-1}\right]$.

O número de Reynolds mostra-nos os níveis de turbulência, abaixo de $R e=2000$ (crítico) o fluxo tende a ser laminar e acima, turbulento. Com o aumento da velocidade dos reagentes, a altura da chama laminar aumenta progressivamente até a transição com a região de mistura turbulenta. A turbulência em chamas aparece com a diminuição gradual do comprimento da chama, onde a base da mistura turbulenta é assentada sobre a saída, apresentando um movimento caótico no interior de chama, ver figura (4).

\footnotetext{
${ }^{9}$ TURNS, S. R. An Introduction to Combustion. McGraw-Hill Inc., 1996.
} 


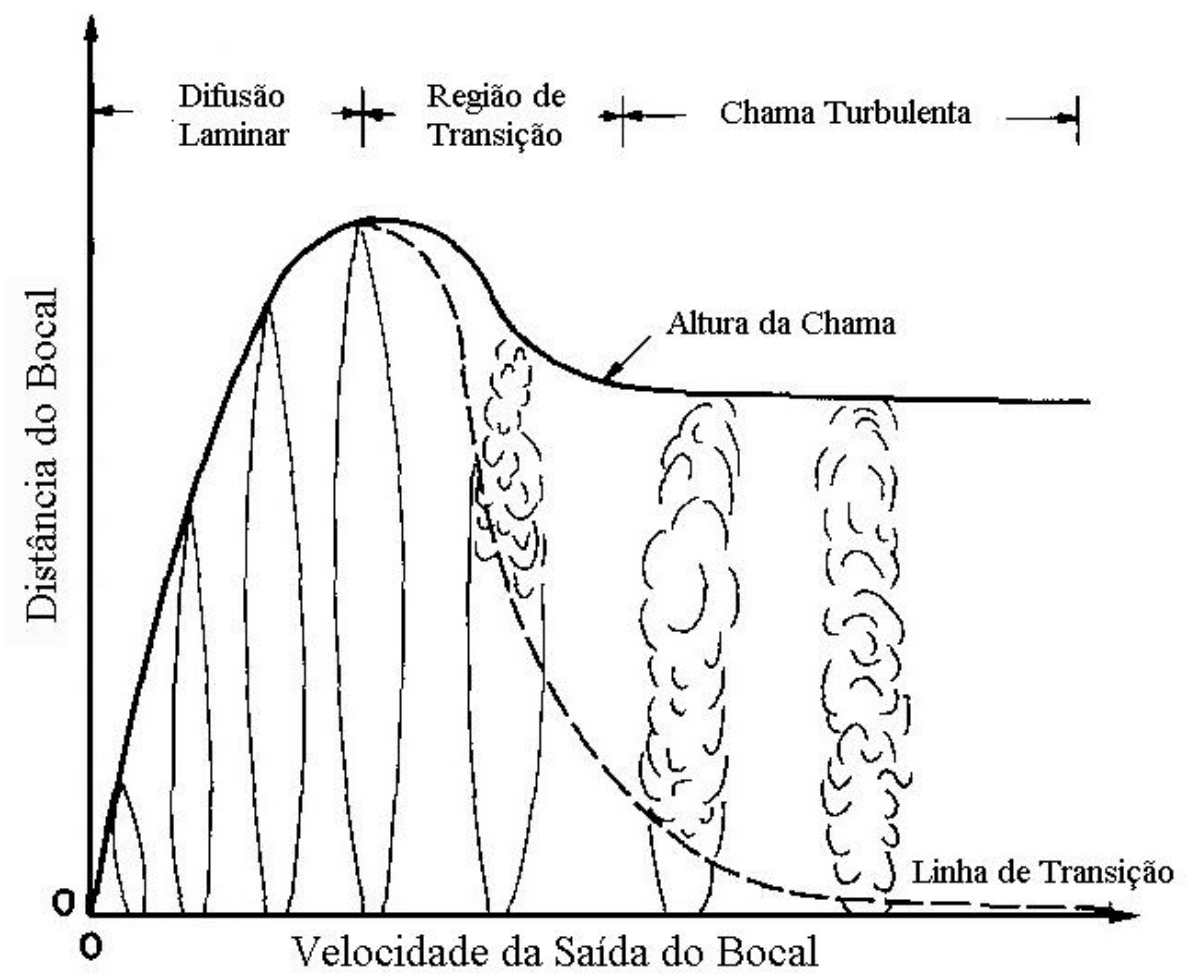

Figura 4 - Variação do formato da chama difusiva com a velocidade.

Fonte: Kuo (1986).

\subsection{3 - Temperatura Adiabática de Chama}

Segundo Wylen et al. (2003), considerando um processo que ocorre adiabaticamente e sem envolver trabalho ou variações de energia cinética ou potencial, a temperatura atingida pelos produtos é chamada de temperatura adiabática de chama. Esta é a máxima temperatura que pode ser atingida pelos produtos de combustão, pois qualquer combustão incompleta tenderia a diminuir a temperatura dos produtos. A máxima temperatura adiabática de chama que pode ser atingida por um certo combustível em um dado estado dos reagentes ocorre quando a mistura é estequiométrica. A temperatura adiabática pode ser controlada pela quantidade de excesso de ar que é utilizada.

Pode-se calcular a temperatura adiabática de chama através da entalpia de formação dos produtos de combustão, aplicando-se a primeira lei e assumindo que o processo é adiabático, as seguintes equações para um excesso de ar de $20 \%$ na combustão do óleo diesel são obtidas: 


$$
\begin{aligned}
& C_{13} \mathrm{H}_{28}+1,2 * 20\left(\mathrm{O}_{2}+3,76 \mathrm{~N}_{2}\right) \rightarrow 13 \mathrm{CO}_{2}+14 \mathrm{H}_{2} \mathrm{O}+4 \mathrm{O}_{2}+90,24 \mathrm{~N}_{2} \\
& H_{R}=H_{P} \\
& \sum_{R} n_{e}\left(\bar{h}_{f}^{o}+\Delta \bar{h}\right)_{e}=\sum_{P} n_{s}\left(\overline{h_{f}^{o}}+\Delta \bar{h}\right)_{s} \\
& H_{R}=\bar{h}_{f}^{o} \quad\left[k J \mathrm{kmol}^{-1}\right] \quad(\mathrm{SPIERS}, 1952) \\
& H_{P}=13\left(-39357473 \quad \bar{h}_{\mathrm{CO} 2}\right)+14\left(-241827+\Delta \bar{h}_{H 2 O}\right)+4 \Delta \bar{h}_{O 2}+90,24 \Delta \bar{h}_{N 2}
\end{aligned}
$$

Onde $\overline{h_{f}^{o}}$ é a entalpia de formação no estado padrão $\left(0,1 \mathrm{MPa}, 25^{\circ} \mathrm{C}\right)\left[\mathrm{kJ} \mathrm{kmol}^{-1}\right]$ e $\Delta \bar{h}$ é igual a $\bar{h}^{o}-h_{25^{\circ} \mathrm{C}}^{-}$, para os produtos de combustão [kJ kmol ${ }^{-1}$ ] (tabela A.9 Wylen et al., 2003). Fazendo cálculos interativos para diferentes temperaturas e interpolando os resultados obtidos, tem-se uma temperatura adiabática de chama de $1859,84^{\circ} \mathrm{C}$ para o diesel com $20 \%$ de excesso de ar.

Rhine e Tucker (1991) estudaram um queimador a gás com objetivo de obter dados sobre o calor trocado entre a chama, a parede da câmara de combustão e a água de resfriamento. Os pesquisadores obtiveram resultados apresentados na figura (5), em forma de temperatura de produtos de combustão e temperatura do tubo. O combustível utilizado foi o gás natural e as linhas contínuas representam os valores das temperaturas calculadas para carga total e meia carga, e os pontos no gráfico são os resultados obtidos experimentalmente. 


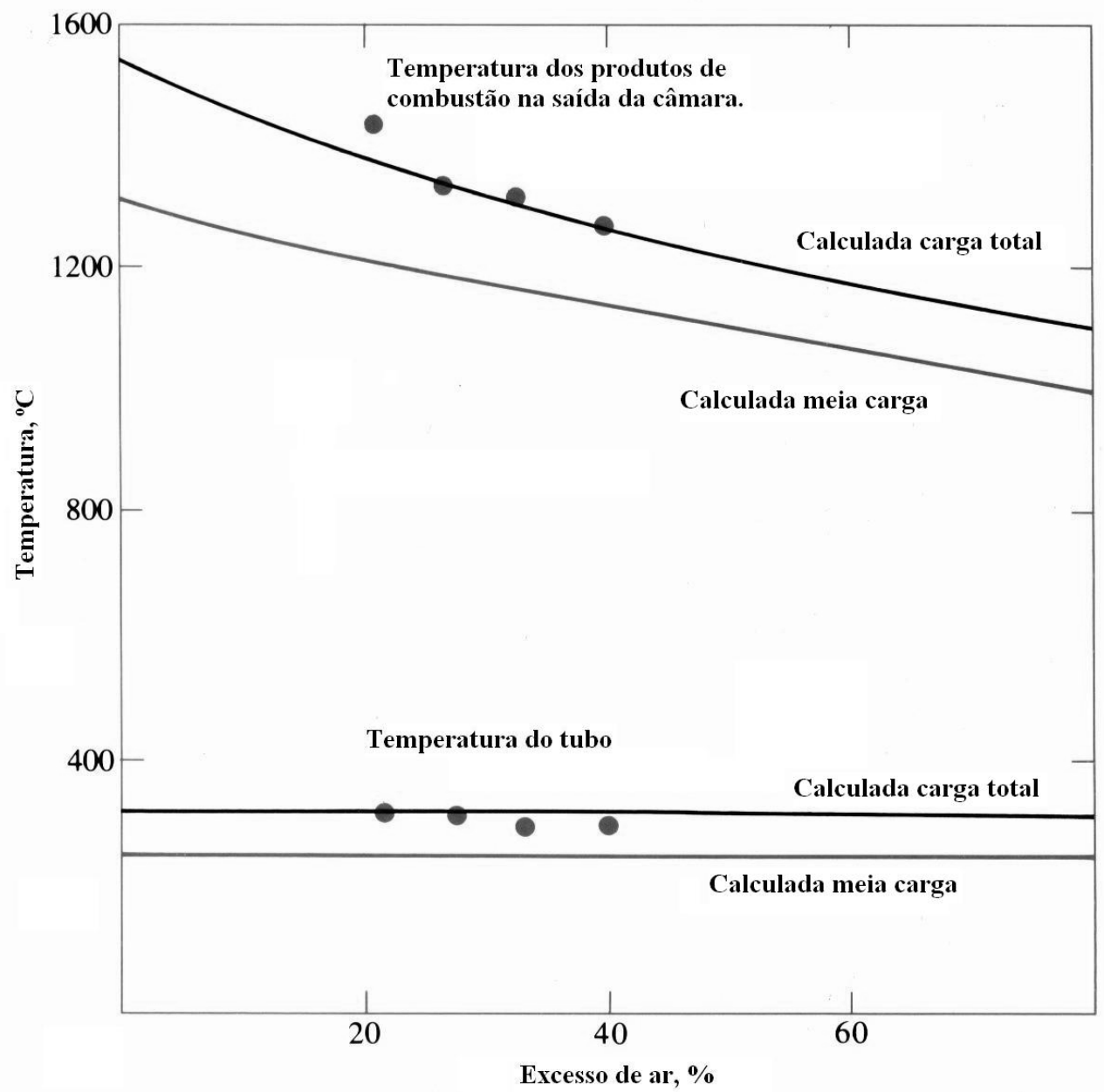

Figura 5 - Efeito do excesso de ar na temperatura dos produtos de combustão e na temperatura do metal.

Fonte: Rhine e Tucker (1991).

É importante salientar que a transferência de calor em uma fornalha está intimamente ligada à temperatura de chama. Em pesquisa realizada por Annaratone (1983), observou-se que, em uma fornalha flamotubular, o pico de transferência de calor está em uma zona a cerca de um diâmetro do bico do queimador, quando esta possuir uma câmara de combustão com diâmetro igual a $1 \mathrm{~m}$, e quando possuir uma câmara de combustão com diâmetro inferior ou superior a $1 \mathrm{~m}$, através da raiz quadrada do diâmetro em metros obtém-se o comprimento da referida zona de transferência. Annaratone mostrou que se variando a entrada de energia, conseqüentemente, varia-se a temperatura de chama e a liberação de calor para as paredes da fornalha. Os resultados obtidos por Rhine e Tucker (1991) comprovam o mesmo efeito, como pode ser visto na figura (6), onde a linha contínua corresponde aos valores calculados e os pontos aos resultados obtidos experimentalmente. 


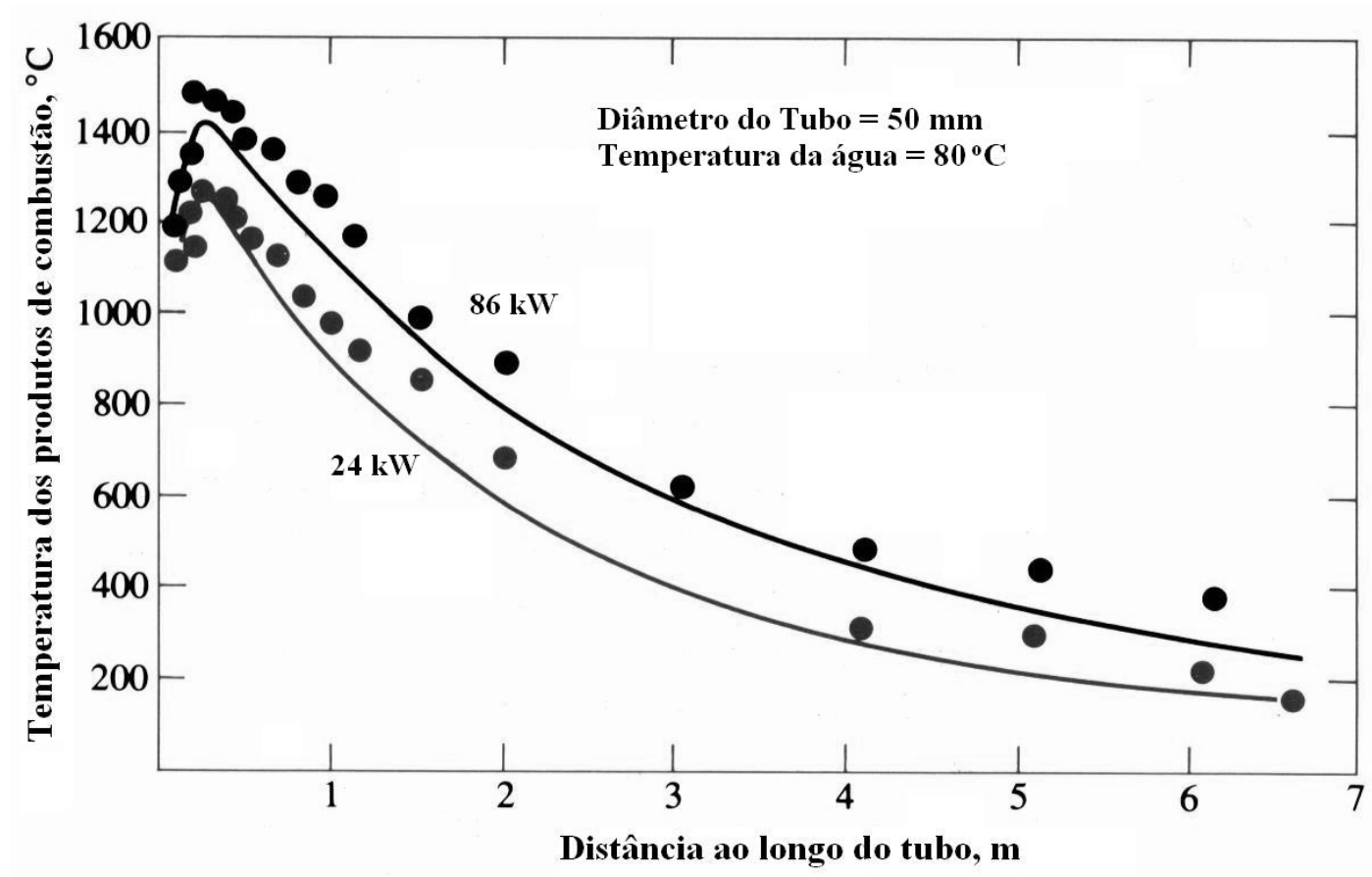

Figura 6 - Temperaturas dos produtos de combustão ao longo da fornalha.

Fonte: Rhine e Tucker (1991).

Através de pesquisa feita por Wu (1969), comparando o desempenho de dois combustíveis (gás natural e óleo diesel) queimados em uma fornalha, notou-se que o óleo diesel proporcionou maior transferência de calor para as paredes da câmara de combustão na região de máxima transferência quando comparado com o gás. Wu justifica este fato através da emissividade da chama elevada do óleo diesel e por conseqüência sua temperatura adiabática de chama maior (ver figuras 7 e 8). Os testes foram realizados sob mesmas condições para ambos os combustíveis. 


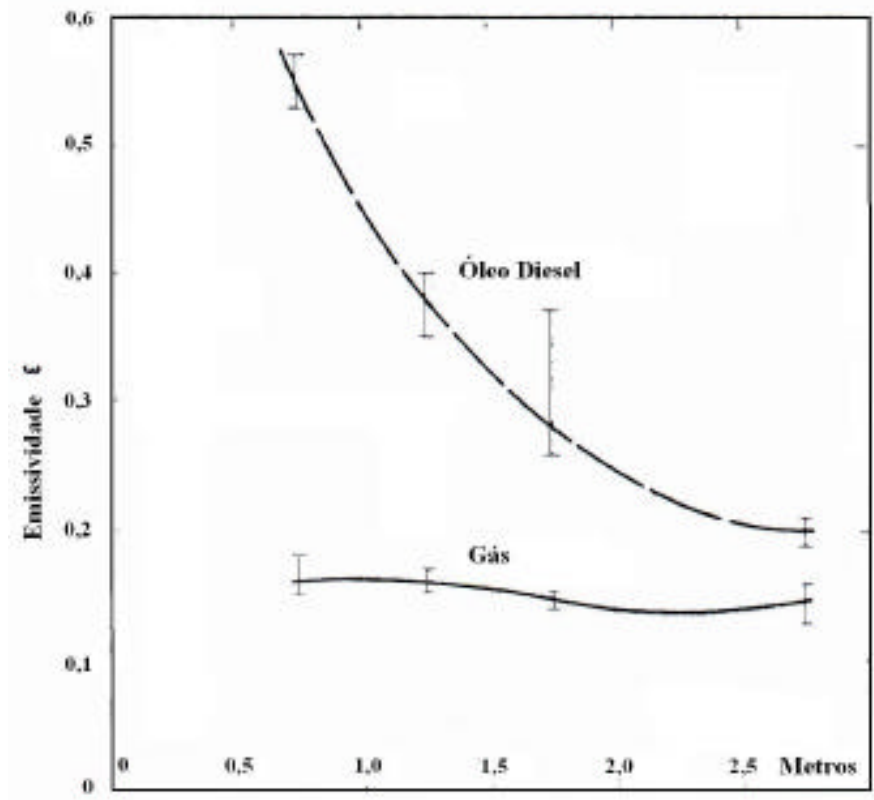

Figura 7 - Comparação entre a emissividade de chama do óleo diesel e do gás em um queimador.

Fonte: Wu (1969).

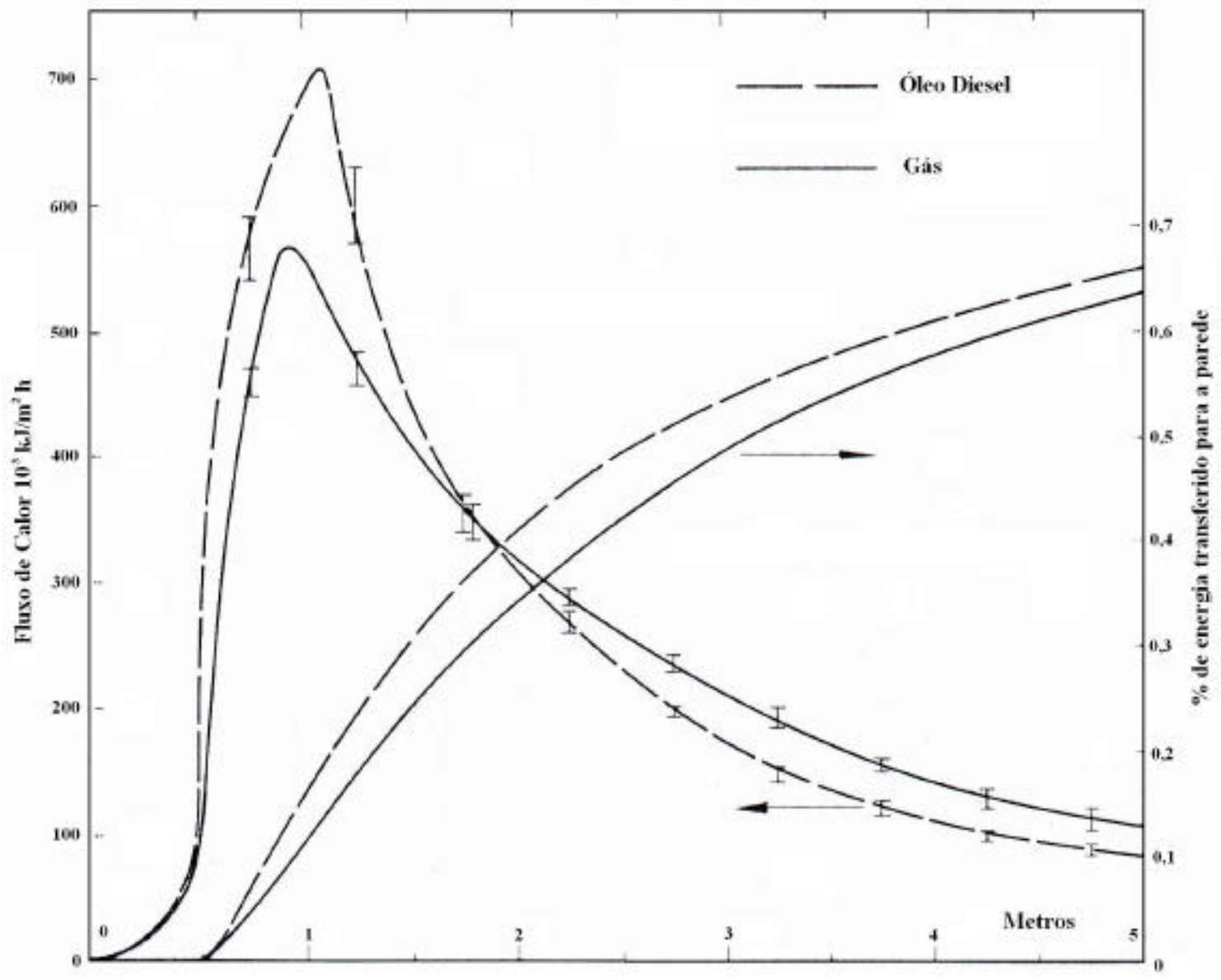

Figura 8 - Distribuição do fluxo de calor e calor transferido acumulativo em uma fornalha. Fonte: Wu (1969). 


\section{3 - Transferência de Calor em Fornalha}

Segundo Gunn e Horton (1989), a fornalha e a câmara de reversão de tubo compreendem somente $10 \%$ da superfície de transferência de calor de uma caldeira, mesmo assim, representa cerca de 40 a $50 \%$ de calor transferido.

A transferência de calor em um sistema representa a energia em trânsito, dada por um gradiente de temperatura. A diferença de temperatura age como uma força que permite o calor fluir. Em fornalhas, o calor é proveniente de uma chama por condução, convecção e radiação. Dos três processos de transferência de calor, a radiação é o que apresenta maior contribuição às altas temperaturas (GRIFFITHS; BARNARD, 1996).

\subsection{1 - Condução}

A condução refere-se ao total de calor transmitido das partículas de substâncias com mais energia para outras com menos energia, devido a interação entre essas partículas.

O fluxo de calor $\dot{Q}_{\text {cond }}$ representa a taxa de transferência de calor por unidade de área, e é calculado através da equação (30).

$$
\dot{Q}_{\text {cond }}=K\left(\frac{T_{1}-T_{2}}{L}\right) \quad\left[W m^{-2}\right]
$$

Onde $K$ é a condutividade térmica do material $\left[\mathrm{W} \mathrm{m}^{-1} \mathrm{~K}^{-1}\right], L$ é a espessura por onde o calor é conduzido [m], e $T_{1}$ e $T_{2}$ são as temperaturas das faces do meio material [K]. O calor de condução [W] é calculado pelo produto do fluxo e área perpendicular à direção da transferência de calor, conforme ilustra a figura (9). 


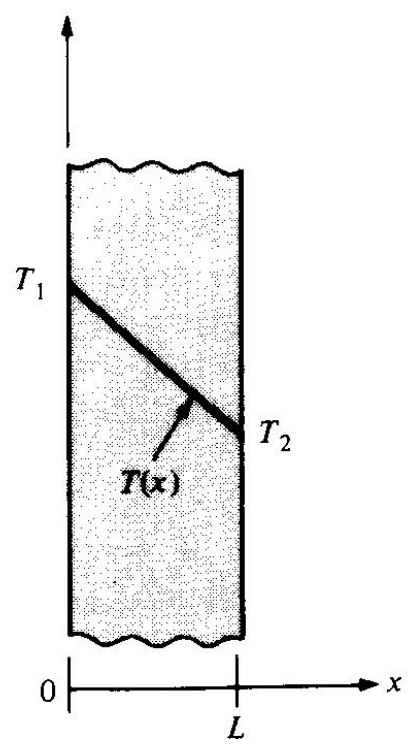

Figura 9 - Condução de calor através de uma placa.

Fonte: Özisik (1990).

\subsection{2 - Convecção}

O mecanismo de transferência de calor convectivo é sustentado pelo movimento aleatório das moléculas e pelo movimento do fluido. Logo, com um maior número de moléculas agregadas, o movimento aumenta a transferência de calor quando na presença de um gradiente de calor. Este mecanismo é explicado considerando uma superfície préaquecida (ver figura 10). A temperatura da superfície é representada por $T_{w}$, a temperatura do fluido $\left(T_{f}\right)$ em um ponto infinitamente distante da superfície, e $h_{\text {conv }}$ representa o coeficiente de transferência de calor convectivo $\left[\mathrm{W} \mathrm{m}^{-2} \mathrm{~K}^{-1}\right]$.

$$
\dot{Q}_{\text {conv }}=h_{\text {conv }}\left(T_{w}-T_{f}\right) \quad\left[W m^{-2}\right]
$$




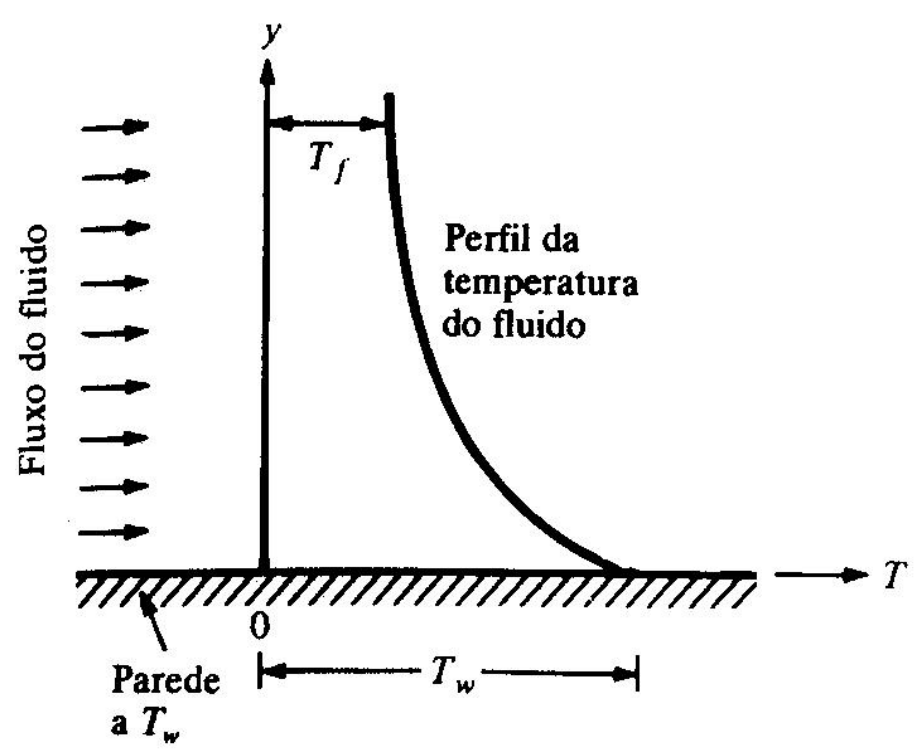

Figura 10 - Transferência de calor por convecção de uma parede para um fluido com temperatura inferior.

Fonte: Özisik (1990).

\subsection{3 - Radiação}

A radiação é formalmente definida como a energia transferida por radiação eletromagnética. Todos os corpos emitem continuamente energia em virtude de sua temperatura, a energia assim definida é denominada radiação térmica. Essa forma de transferência permite a troca de energia entre corpos sem a presença de um meio comunicante. Um exemplo clássico são os raios solares.

O fluxo mássico $\left[\mathrm{W} \mathrm{m}^{-2}\right]$ emitido por radiação de uma superfície para outra é chamado de radiação de corpo negro, como definido pela Lei de Stefan-Boltzmann (INCROPERA; DEWITT, 1990) e mostrado na equação (32).

$$
\dot{Q}_{\text {rad }}=s T_{s}^{4} \quad\left[W m^{-2}\right]
$$

Onde: $T_{s}$ é a temperatura da superfície $[\mathrm{K}]$ e $s$ é a constante de StefanBoltzmann $\left[5,67 \times 10^{-8} \mathrm{~W} \mathrm{~m}^{-2} \mathrm{~K}^{-4}\right]$. Mas, o fluxo de calor da superfície real é menor que o emitido pela superfície ideal (corpo negro) como mostrado pela equação (33).

$$
\dot{Q}_{\text {rad }}=s \varepsilon T_{s}^{4} \quad\left[W m^{-2}\right]
$$


Onde: $e$ é a emissividade do material (propriedade radiante) $(0=e=1)$.

Já o fluxo de troca de calor entre a superfície e suas vizinhanças, pode ser calculado pela equação (34), onde $T_{v i z}$ é a temperatura das vizinhanças.

$$
\dot{Q}_{\text {rad }}=s \varepsilon\left(T_{s}^{4}-T_{v i z}^{4}\right) \quad\left[W m^{-2}\right]
$$

Nas fornalhas a óleo ou a gás, o pico de transferência de calor ocorre a uma distância equivalente a um diâmetro a partir do injetor do queimador. Essa taxa de transferência pode atingir $320 \mathrm{KW} \mathrm{m}{ }^{-2}$ ou mais. Assim, nesta região ocorre a mais alta temperatura do metal nas paredes da fornalha.

A figura (11) mostra a relação entre o diâmetro mínimo da fornalha e o fluxo de calor que é permitido fornecer a ela. Observa-se que o máximo de calor permitido introduzir a uma fornalha é $12 \mathrm{MW}$ para a queima de óleo, gás ou carvão pulverizado. Já para a queima de combustíveis sólidos sobre grelhas é de $8 \mathrm{MW}$. Para uma introdução de calor superior a isto, duas ou mais fornalhas devem ser usadas. O fluxo de calor médio fornecido à fornalha é geralmente um pouco menor que a metade do valor de pico, mas é consideravelmente maior do que aquele que ocorre no restante da caldeira, excetuando o espelho de tubos.

As fornalhas tubulares são geralmente usadas nas caldeiras flamotubulares que queimam gás ou óleo para fornecimento de calor. Os processos de combustão, a forma e o comprimento de chama dependem de um certo espaço necessário para que ocorram. $\mathrm{O}$ cálculo de uma fornalha deve considerar que a combustão ocorre num determinado intervalo de tempo e a fornalha deve envolver completamente a chama, sem que esta toque nas paredes metálicas. Portanto, um certo volume e certas proporções de diâmetro e comprimento de fornalha são necessários. No Reino Unido, para as fornalhas que queimam combustíveis gasosos ou óleo, recomendam-se valores até 1,8 $\mathrm{MW} \mathrm{m}{ }^{-3}$ (relação entre o calor introduzido por volume da fornalha). Não entram nesta relação o volume da câmara de reversão e o volume ocupado pelo cone de refratário do queimador. Nos Estados Unidos esta relação é de 1,55 $\mathrm{MW} \mathrm{m}^{-3}$, porém, o volume da câmara de reversão entra no cálculo. 


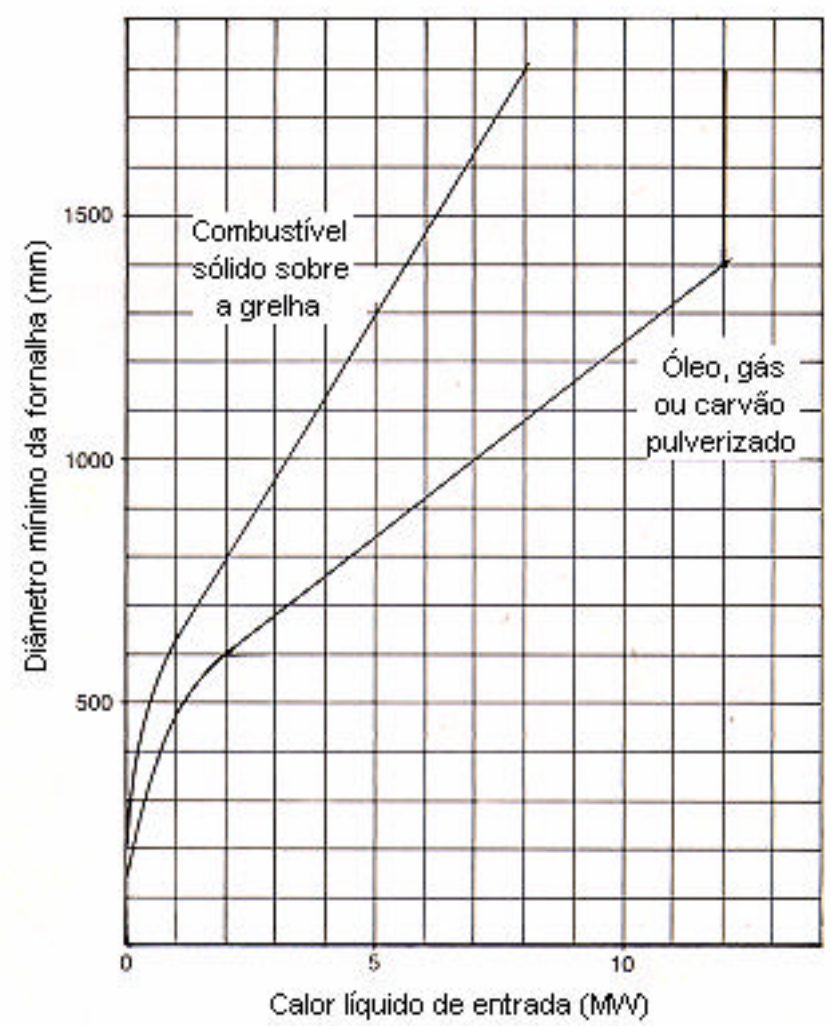

Figura 11 - Relação entre o mínimo diâmetro interno da fornalha e o calor líquido introduzido. Fonte: British Standard BS2790 (1986).

\subsection{4 - Avaliação Térmica de uma Célula Calorimétrica}

A capacidade que a água tem de transportar calor em cada célula calorimétrica da fornalha é determinada pela seguinte fórmula:

$$
\dot{Q}=\dot{m} c_{p} \Delta T \quad[k W]
$$

Onde: $\dot{Q}$ é a taxa de transporte de calor pela água $[\mathrm{kW}], \dot{m}$ é a descarga de água através de cada célula $\left[\mathrm{kg} \mathrm{s}^{-1}\right], c_{p}$ é $4,184\left[\mathrm{~kJ} \mathrm{~kg}^{-1}{ }^{\circ} \mathrm{C}^{-1}\right]$ (calor específico da água à pressão constante) e $\Delta T$ é a diferença de temperatura entre a saída e a entrada de água $\left[{ }^{\circ} \mathrm{C}\right]$.

Gunn e Horton (1989) e Gunn (1973) disseram que a transferência de calor na fornalha acontece principalmente por radiação, onde o fluxo de calor (calor por unidade de área) é mais intenso. O pico de taxa de transferência de calor, ao longo da fornalha, 
acontece a uma distância do queimador de valor igual à aproximadamente um diâmetro da fornalha.

\subsubsection{1 - Coeficiente de Transferência de Calor das Células Calorimétricas}

O coeficiente de transferência de calor médio de cada célula calorimétrica pode ser determinado por:

$$
h_{m}=\frac{\dot{Q}}{\pi D L \Delta T}=\frac{\dot{Q}}{\pi D L\left(T_{p}-T_{\infty}\right)} \quad\left[k W m^{-2 o} C^{-1}\right]
$$

A temperatura de parede $\left(T_{p}\right)$ pode ser determinada, através de cálculo interativo que leva em conta a temperatura de saturação do vapor na pressão de trabalho, a resistência térmica através das paredes da fornalha, o comprimento, o diâmetro interno e externo da fornalha e calor transferido.

$$
T_{p}=T_{s a t}+\frac{\dot{Q_{R}}}{2 \pi k L_{f}} \ln \left(\frac{D_{e f}}{D_{i f}}\right)
$$

Onde: $T_{p}$ é a temperatura da parede interna da fornalha $[\mathrm{K}], T_{\text {sat }}$ é a temperatura de saturação da água $[\mathrm{K}], \dot{Q}_{R}$ é o calor transferido por radiação na fornalha $[\mathrm{kW}], k$ é o coeficiente de condutividade térmica do material da fornalha $\left[\mathrm{kW} \mathrm{m} \mathrm{m}^{-1} \mathrm{~K}^{-1}\right]\left(k_{\text {aço }} \cong\right.$ 0,059), $L_{f}$ é o comprimento da fornalha $[\mathrm{m}], D_{e f}$ é o diâmetro externo da fornalha $[\mathrm{m}]$ e $D_{i f}$ é o diâmetro interno da fornalha [m].

Através de cálculos efetuados, pôde-se notar que no interior da fornalha temos a chama com temperatura da ordem de $T_{g}=2225,8 \mathrm{~K}$ e pelo lado externo temos a água na temperatura de saturação $T_{\text {sat }}=431,8 \mathrm{~K}$. Mesmo considerando o absurdo da totalidade do calor fornecido pelo combustível ser trocado na fornalha, observa-se que a temperatura da parede interna da fornalha é influenciada mais pela temperatura de saturação da água do que pela temperatura da chama. Notamos que a temperatura da chapa da fornalha é de, no máximo, 23,45 graus superior à temperatura de saturação. Portanto, é razoável adotar para temperatura da parede interna da fornalha 
$T_{p}=T_{\text {sat }}+20$; isto evita o cansativo trabalho de interação. Sabendo que em nosso objeto de estudo a água não entra em ebulição, a relação a seguir torna-se verdadeira:

$$
T_{p}=T_{s a t}+10
$$

Segundo Özisik (1990), a temperatura da parede pode ser estimada pela média entre a temperatura de entrada e a temperatura de saída (esta relação também foi mostrada por Incropera e Dewitt, 1992). Logo, para a determinação do coeficiente de transferência de calor das células calorimétricas, teremos:

$$
\begin{aligned}
& T_{P}=\frac{T_{e}+T_{s}}{2}+10 \\
& T_{\infty}=T_{e}
\end{aligned}
$$

Uma outra forma de determinar o coeficiente de transferência de calor médio de cada célula é usando a correlação de Whitaker desenvolvida para escoamento de gases e líquidos, transversal a um cilindro isolado:

$$
N u_{m}=\frac{h_{m} D}{k}=\left(0,4 \operatorname{Re}^{0,5}+0,06 \operatorname{Re}^{2 / 3}\right) \operatorname{Pr}^{0,4}\left(\frac{\mu_{\infty}}{\mu_{p}}\right)^{0,25}
$$

Onde:

$$
\begin{array}{ll}
\operatorname{Pr}_{T^{o} C} & 0,67<\operatorname{Pr}<300 \\
\mu=v . \rho & 0,25<\frac{\mu_{\infty}}{\mu_{p}}<5,2
\end{array}
$$

Que concorda com os dados experimentais dentro de $\pm 25 \%$.

O Número de Reynold para escoamento transversal a um cilindro circular isolado é calculado por:

$$
R e=\frac{U_{\infty} D}{v} \quad 40<R e<105
$$


Onde: $U_{\infty}$ é a velocidade da corrente livre $\left[\mathrm{m} \mathrm{s}^{-1}\right.$ ], $D$ é o diâmetro do cilindro [m] e $v_{c}$ é a viscosidade cinemática do fluido $\left[\mathrm{m}^{2} \mathrm{~s}^{-1}\right]$.

A velocidade da corrente livre pode ser calculada pela lei da conservação da massa aplicada ao tubo de alimentação de cada célula calorimétrica:

$$
U_{\infty}=\frac{\dot{m}}{\rho A_{t}}
$$

Onde: $\quad A_{t}=\frac{\pi d_{t}^{2}}{4}$

Conforme estudo realizado por Santos e Souza (2004), em uma análise feita em uma única célula calorimétrica, observou-se que o coeficiente de transferência de calor calculado corresponde a obtido experimentalmente, estando este dentro da faixa de tolerância para os cálculos.

\section{4 - Fundamentos Teóricos da Chaminé}

A chaminé é de fundamental importância no processo de tiragem dos gases de combustão de uma fornalha, especialmente se a tiragem for do tipo natural; onde os gases são retirados sem o auxílio de ventiladores mecânicos. $\mathrm{O}$ fundamento do funcionamento da chaminé em tiragem natural está no fato que o peso dos gases aquecidos no interior da chaminé é menor que o peso de um mesmo volume de ar na temperatura ambiente. Portanto, essa diferença gera uma força de empuxo que é proporcional à diferença de peso específico, conforme a equação:

$$
F_{e}=A \cdot H_{u} \cdot\left(\rho_{a}-\rho_{g}\right) \cdot g
$$

$$
\text { Sendo, } \quad \frac{F_{e}}{A}=\Delta P_{c}
$$

Teremos, $\quad \Delta P_{c}=H_{u} \cdot\left(\rho_{a}-\rho_{g}\right) \cdot g$ 
Onde: $F_{e}$ é a força de empuxo [N], ? $P_{c}$ é a depressão gerada pela chaminé $[\mathrm{Pa}]$, $A$ é a área transversal da chaminé $\left[\mathrm{m}^{2}\right], H_{u}$ é a cota da chaminé entre a linha de centro do queimador e o topo da chaminé, também denominada de altura útil $[\mathrm{m}], \rho_{a}$ é a massa específica do ar na temperatura ambiente $\left[\mathrm{kg} \mathrm{m}^{-3}\right], \rho_{g}$ é a massa específica do gás na temperatura média do gás na chaminé $\left[\mathrm{kg} \mathrm{m}^{-3}\right]$ e $g$ é a aceleração da gravidade $\left[\mathrm{m} \mathrm{s}^{-2}\right.$ ] $( \pm 9,8)$.

No caso de tiragem natural, a depressão gerada pela chaminé deve ser capaz de vencer todas as perdas de carga no circuito do ar e dos gases (entrada de ar, perdas localizada, fornalha, tubos de gases e na própria chaminé). A altura útil mínima da chaminé é calculada por:

$$
H_{u m}=\frac{\Delta P}{\left(\rho_{a}-\rho_{g}\right) \cdot g}
$$

Sendo: ?P a perda de carga global no circuito do ar e dos gases [Pa].

O diâmetro médio da chaminé pode ser calculado com base na descarga prevista de gases, usando a seguinte fórmula:

$$
d_{m}=\left(\frac{4 . \dot{m}_{g}}{\pi \cdot \rho_{g} \cdot v_{g}}\right)^{1 / 2}
$$

Onde: $d_{m}$ é o diâmetro médio da chaminé $[\mathrm{m}], \dot{m}_{g}$ é a descarga de gases $\left[\mathrm{kg} \mathrm{s}^{-1}\right]$, $v_{g}$ é a velocidade dos gases $\left[\mathrm{m} \mathrm{s}^{-1}\right]$.

Bazzo (1992) diz que para tiragem natural a velocidade é arbitrada entre 4 e 6 m $\mathrm{s}^{-1}$ e que, para tiragem forçada, a velocidade pode ser superior a $10 \mathrm{~m} \mathrm{~s}^{-1}$. Entretanto, quanto maior é a velocidade maior é a perda de carga na chaminé.

Uma forma fácil de prever a descarga de gás através da chaminé é seguir o seguinte raciocínio:

$$
\dot{m}_{g, \text { real }}=\dot{m}_{\text {ar, real }}+\dot{m}_{c}
$$


Considerando que: $\dot{m}_{\text {ar, real }}=\lambda \cdot \dot{m}_{a r, e s t .}$

E dividindo ambos os termos pela descarga de combustível,

$$
\frac{\dot{m}_{g, \text { real }}}{\dot{m}_{c}}=\frac{\lambda \cdot \dot{m}_{\text {ar,est. }}}{\dot{m}_{c}}+1
$$

Teremos:

$$
\dot{m}_{g, r e a l}=\dot{m}_{c}\left(\lambda . A C_{e s t .}+1\right)
$$

No cálculo da chaminé é necessário atentar que diâmetros muito grandes em relação à altura útil resulta em velocidade do gás muito baixa, ocasionando a redução da temperatura do gás e permitindo a entrada de ar pelo topo da chaminé. Altura útil muito grande em relação ao diâmetro provoca perda de carga excessiva na chaminé e também, redução da temperatura. A redução da temperatura do gás provoca a condensação do vapor d'água nele contido, que possibilita a formação de ácidos corrosivos. Bazzo (1992) recomenda que quando a relação $H_{u} / d$ for superior a 30, utilizar a tiragem forçada, e fornece a metodologia para o preciso cálculo da massa específica dos gases e fornece também o gráfico em anexo que nos permite ter uma idéia da faixa na qual a massa específica dos gases de combustão encontra-se em função da temperatura dos mesmos (ver Anexo IV).

\section{4 - Queimadores de Combustíveis em Fornalhas Flamotubulares}

Queimadores de combustíveis, na sua essência, são dispositivos mecânicos que têm a capacidade de realizar a oxidação de combustíveis que possuam constituintes passiveis de serem oxidados (PAGLIUSO, 1984).

Os queimadores de combustíveis gasosos estudados por Delabroy et al. (1998), possuem estrada central de combustível e quatro saídas de jatos retangulares curvados, o combustível é inserido de forma normal ao eixo do queimador. O estudo das interações entre os jatos é muito complexo, e em todos os queimadores o momento do jato de combustível é muito pequeno comparado com o momento do jato de ar. 
O Canadian Gas Research Institute (CGRI), em colaboração com o Centre for Advanced Gas Combustion Technology (CAGCT) realizaram testes em um novo modelo de queimador. A idéia básica utilizada foi alterar a disposição do jato de combustível e do jato de ar, aumentando o número de gotículas de combustível no conduto que fornece os reagentes para a combustão. É importante ressaltar que ambos os jatos são rearranjados de maneira circular, um jato de ar entre dois jatos de combustível.

Delabroy et al. (1998) também estudaram queimadores de combustíveis líquidos, e a primeira configuração estudada por eles foi usando uma caldeira Viessmann, esta caldeira é equipada com um recirculador de gases de exaustão, com o objetivo de diminuir a formação de $\mathrm{NO}_{\mathrm{x}}$. $\mathrm{O}$ ar de combustão é introduzido por meio de um ventilador e o queimador usado é idêntico aos modelos comercias (sua potência é de $20 \mathrm{~kW}$ ). O combustível testado tem a fórmula molecular média representada por $\mathrm{C}_{16} \mathrm{H}_{30}$. Como podemos observar na figura (12), o rotor é acionado por um motor elétrico de velocidade variável e possui seis orifícios em ambas as chapas (apesar de experimentos terem mostrado que a maior potência é adquirida quando só estão abertos três orifícios de forma simétrica). Durante o funcionamento, um sensor de pressão monitora as variações que ocorrem nesta câmara (na faixa de 5 a $10 \mathrm{~Pa}$ ).

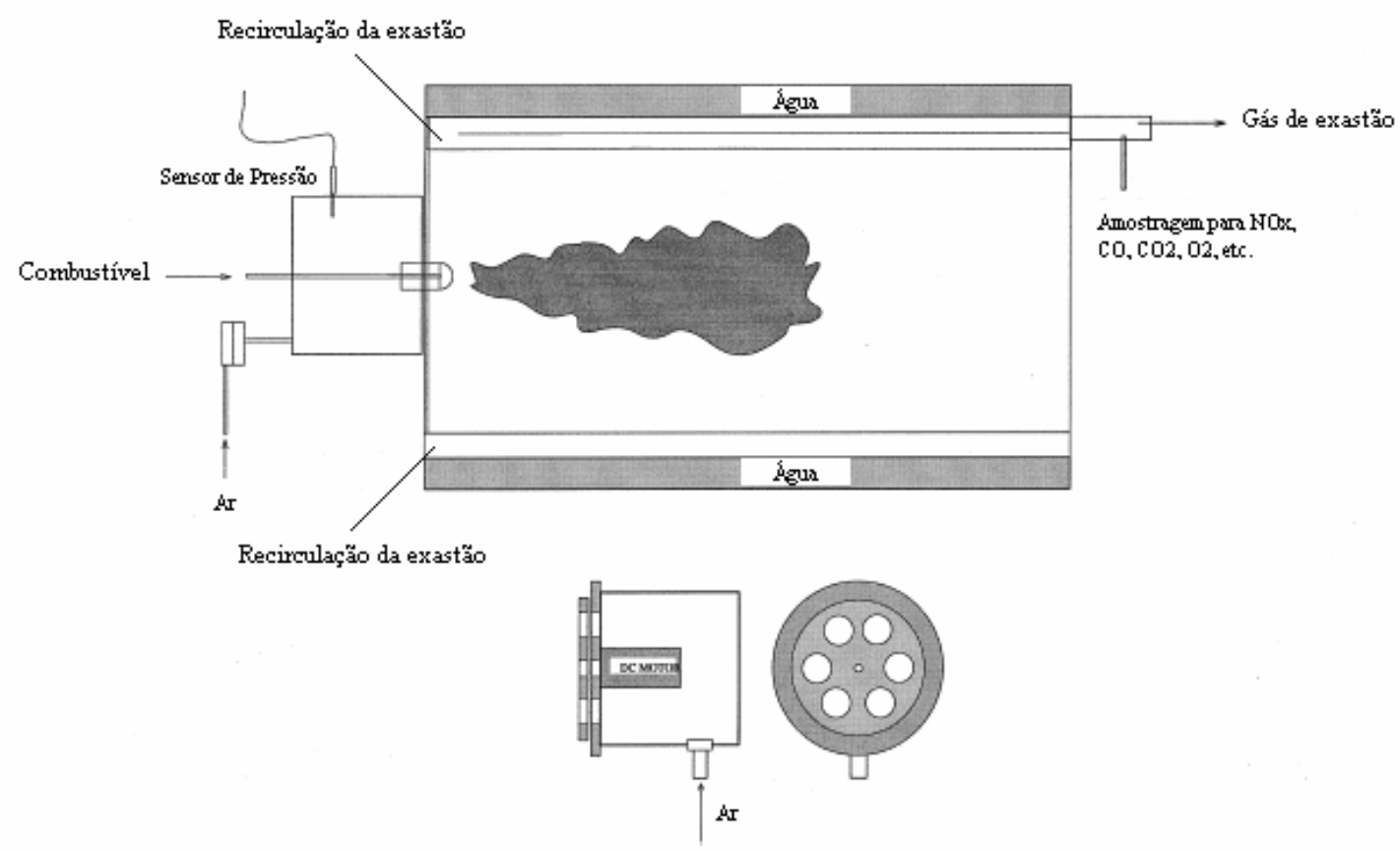

Figura 12 - Ilustração de um queimador de $20 \mathrm{~kW}$.

Fonte: Delabroy et al. (1998). 
Tashtoush et al. (2003), realizaram estudos sobre um queimador de combustíveis líquidos, especificamente óleo diesel e ésteres etílicos de restos de óleos vegetais, comparando-os quanto ao nível de emissões, eficiência de combustão e temperatura de exaustão, variando a razão ar/combustível (A/C) e o fluxo mássico de ambos os combustíveis. Através de análises feitas por estes pesquisadores, foram adotados os seguintes fluxos mássicos de combustível: 3,0 e 5,0 $\mathrm{kg} \mathrm{s}^{-1}$ para o óleo diesel e 3,3 e 5,5 $\mathrm{kg} \mathrm{s}^{-1}$ para o biodiesel de palma, pelo fato do poder calorífico superior (PCS) do óleo diesel ser $10 \%$ superior ao do biodiesel (ver Anexo VI), mantendo assim, a mesma quantidade de energia de entrada na fornalha. Os resultados obtidos indicam claramente que os ésteres etílicos, obtidos através do processo de transesterificação, de restos de óleo de palma são candidatos em potencial para substituírem os combustíveis tradicionais utilizados em fornalhas e caldeiras. Em condições de fluxo de combustíveis relativamente baixas, o biodiesel pode substituir o diesel em termos de desempenho da combustão, no aspecto de eficiência de combustão e temperatura de exaustão, assim como em relação às emissões.

Shokry e El Morsi (1991) estudaram a transferência de calor em uma fornalha flamotubular, horizontal, com sete calorímetros retangulares posicionados ao longo do corpo da câmara de combustão. Para se observar quantitativamente a energia absorvida pela água em cada célula ao longo da fornalha, foi adotado pelos pesquisadores um fator denominado eficiência de absorção [?] (ou rendimento térmico) que foi definido como:

$$
\eta=\frac{\text { calor absorvidoem cada célula }}{\text { calor fornecido pelo combustível }}
$$

Observou-se que, com excesso de ar constante, qualquer aumento no consumo de combustível causa um aumento correspondente na liberação de calor, entretanto este aumento não é proporcional em cada calorímetro. Notou-se também, que o pico de transferência ocorreu em um certo consumo de combustível e em um certo fator de excesso de ar, fora desta situação o valor começa a decrescer, isto devido a uma combustão incompleta. As curvas de transferência de calor têm o mesmo comportamento indicado por outros autores estudados, onde o pico de transferência ocorre nos dois primeiros calorímetros e diminui gradativamente.

Rhine e Tucker (1991), adotaram o mesmo procedimento para definir o rendimento ? da fornalha estudada por eles. Sendo que, o rendimento a cada célula é o 
seu próprio rendimento mais a somatória do rendimento das células anteriores, e isto nos mostra a troca de calor ocorrida na área correspondente à distância longitudinal entre o ponto observado e o bico injetor. Um exemplo é mostrado na figura (13), onde se observa a eficiência calculada e medida da fornalha, para diferentes quantidades de energia fornecida. $\mathrm{O}$ diâmetro da câmara de combustão é de $50 \mathrm{~mm}$ e a temperatura da água é igual a $80{ }^{\circ} \mathrm{C}$, e taxas de $24 \mathrm{~kW}$ (gás natural) e $86 \mathrm{~kW}$ (óleo combustível), com $20 \%$ e $15 \%$ de excesso de ar respectivamente.

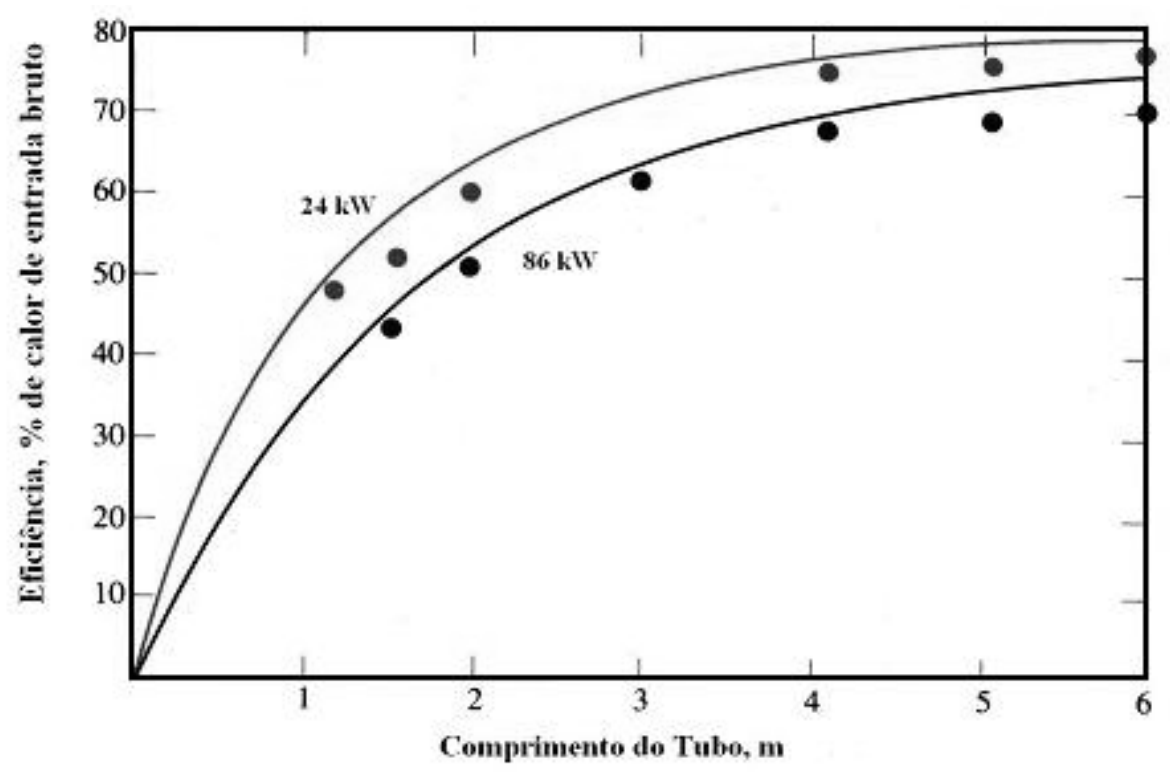

Figura 13 - Comparação entre a eficiência térmica prevista e medida.

Fonte: Rhine e Tucker (1991).

\section{5 - Gases de Exaustão x Fator de Excesso de Ar}

A figura (14) indica a variação das emissões da exaustão em relação ao fator de excesso de ar em um motor de combustão interna, de acordo com Sher ${ }^{10}$ (1998 apud MARTINS, 2003), quando o fator de excesso de ar é igual a 0,7, a queima ocorre com mistura muito rica e as emissões de $\mathrm{CO}$ e $\mathrm{HC}$ são altas nesta região, devido à combustão incompleta provocada pela falta de oxigênio, ocasionando combustível não queimado nos gases de exaustão. Ao contrário, a emissão de $\mathrm{NO}_{\mathrm{x}}$ é insignificante pois o excesso de combustível proporciona a queda da temperatura de combustão. Quando o fator de excesso de ar aumenta para próximo de lambda igual a 1, as emissões de CO e HC diminuem, pois suas oxidações ocorrem na presença de uma concentração maior de

\footnotetext{
${ }^{10}$ SHER, E. Handbook of Air Pollution from Internal Combustion Engines: Pollutant Formation and
} Control. Academic Press: San Diego, USA, 1998. 
oxigênio que resulta num aumento da concentração de $\mathrm{CO}_{2}$ e temperatura de combustão mais elevada, favorecendo a emissão de $\mathrm{NO}_{\mathrm{x}}$. Para valores de $\lambda>1$, que corresponde à faixa de mistura pobre, as concentrações de $\mathrm{CO}$ e HC são baixas, devido à combustão ser completa, o que resulta no máximo de $\mathrm{CO}_{2}$. A concentração de $\mathrm{NO}_{\mathrm{x}}$, a partir de $\lambda=1,15$, diminui por causa do excesso de ar que baixa a temperatura na câmara de combustão.

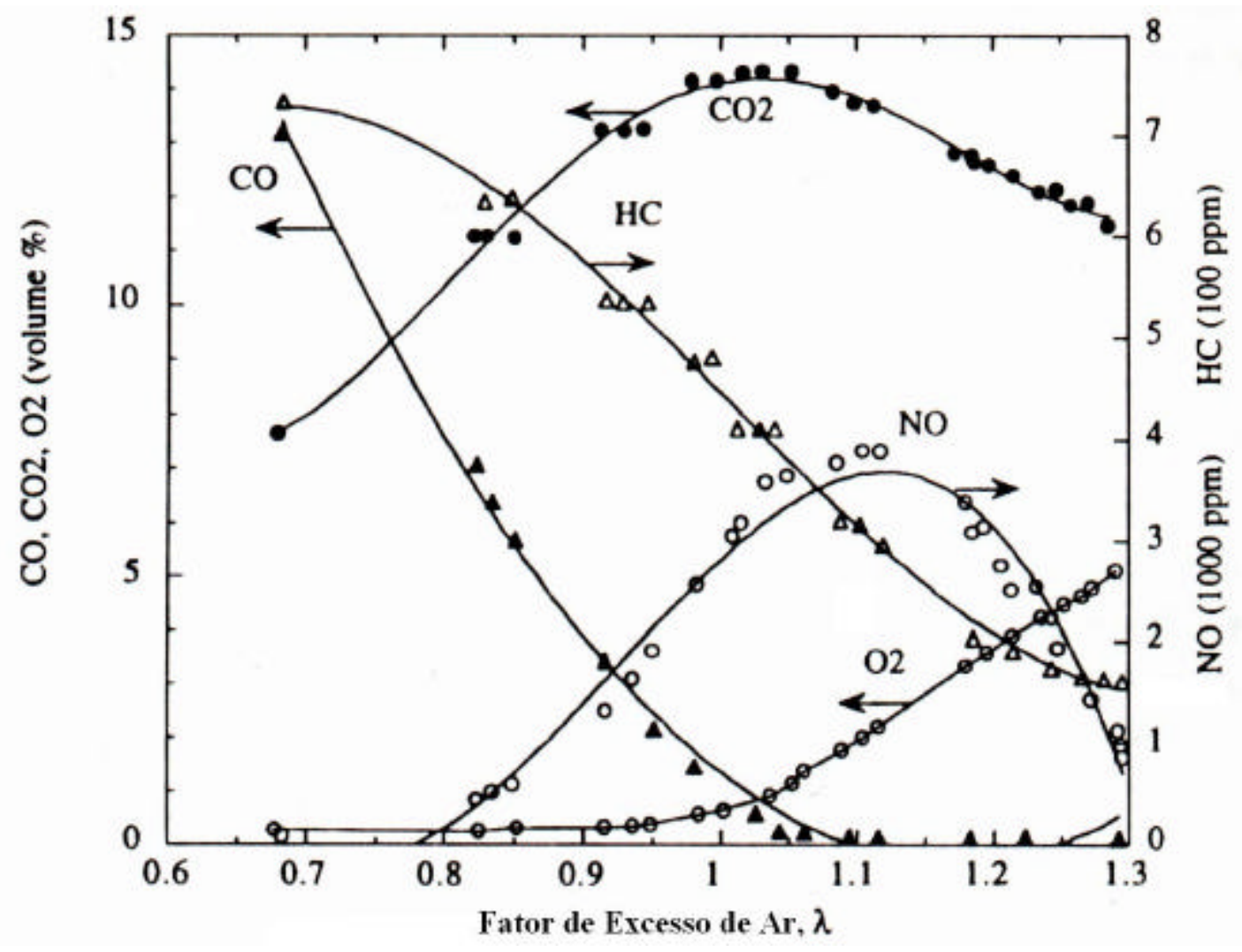

Figura 14 - Variação das emissões em função do fator de excesso de ar (?).

Fonte: Sher (1998).

\section{6 - Espessura da parede das Fornalhas para Caldeiras Flamotubulares}

A ASME VIII (section I - Power Boilers) diz que a espessura das fornalhas de caldeiras flamotubulares, cilíndricas planas não pode ser inferior a $8 \mathrm{~mm}$. A máxima pressão de trabalho permitida (PMTP), deve ser determinada como indicado a seguir.

Nas fórmulas deste item, teremos as seguintes definições: $P$ é a Pressão Máxima de Trabalho Permitida (PMTP) [MPa], $D$ é o diâmetro externo da fornalha $[\mathrm{mm}], e$ é a espessura mínima da fornalha [mm] e $L$ é o comprimento total da fornalha [mm]

a) Para fornalhas com Diâmetro Externo até 152 mm: 


$$
P=96,5 \frac{(e-1,65)}{D}
$$

b) Para fornalhas com Diâmetro Externo de $152 \mathrm{~mm}$ a $460 \mathrm{~mm}$ e que o comprimento da fornalha não ultrapasse 4,5 vezes o diâmetro:

$$
P=\frac{0,355}{D}(300 e-1,03 L), \quad \text { para } \mathrm{L}<120 e
$$

Obs: Quando L for maior que 120 vezes a espessura, usamos:

$$
P=\frac{7500 e^{2}}{L D}
$$

c) Para fornalhas com Diâmetro Externo de $152 \mathrm{~mm}$ a $460 \mathrm{~mm}$ e que o comprimento da fornalha é superior a 4,5 vezes o diâmetro:

$$
P=\frac{68900 e^{3}}{D^{3}}, \quad \text { para } e<0,023 \mathrm{D}
$$

Obs: Quando a espessura for maior que 0,023D, usamos:

$$
P=\frac{119,28 e}{D}-1,90
$$

d) Para fornalhas com Diâmetro de 460 mm (externo) a 970 mm (interno) e que o comprimento da fornalha não exceda 6 vezes o diâmetro:

$$
P=\frac{0,355}{D}(300 e-1,03 L), \quad \text { para } \mathrm{L}<120 e
$$

Obs: Quando L for maior que 120 vezes a espessura, usamos:

$$
P=\frac{7500 e^{2}}{L D}
$$


e) Para fornalhas com Diâmetro de 460 mm (externo) a 970 mm (interno) e que o comprimento da fornalha é superior à 6 vezes o diâmetro:

$$
P=\frac{0,355}{D}(300 e-6,18 L), \quad \text { para } \mathrm{L}<120 e
$$

Obs: Quando L for maior que 120 vezes a espessura, usamos:

$$
P=\frac{7500 e^{2}}{6 D^{2}}
$$




\section{4 - MATERIAIS E MÉTODOS}

A fornalha projetada e construída é do tipo calorimétrica. Para facilitar a construção e reparos e ainda, proporcionar versatilidade de uso, a fornalha foi projetada e construída em quatro módulos iguais. As figuras (15), (16) e (17) mostram os detalhamentos de cada célula.

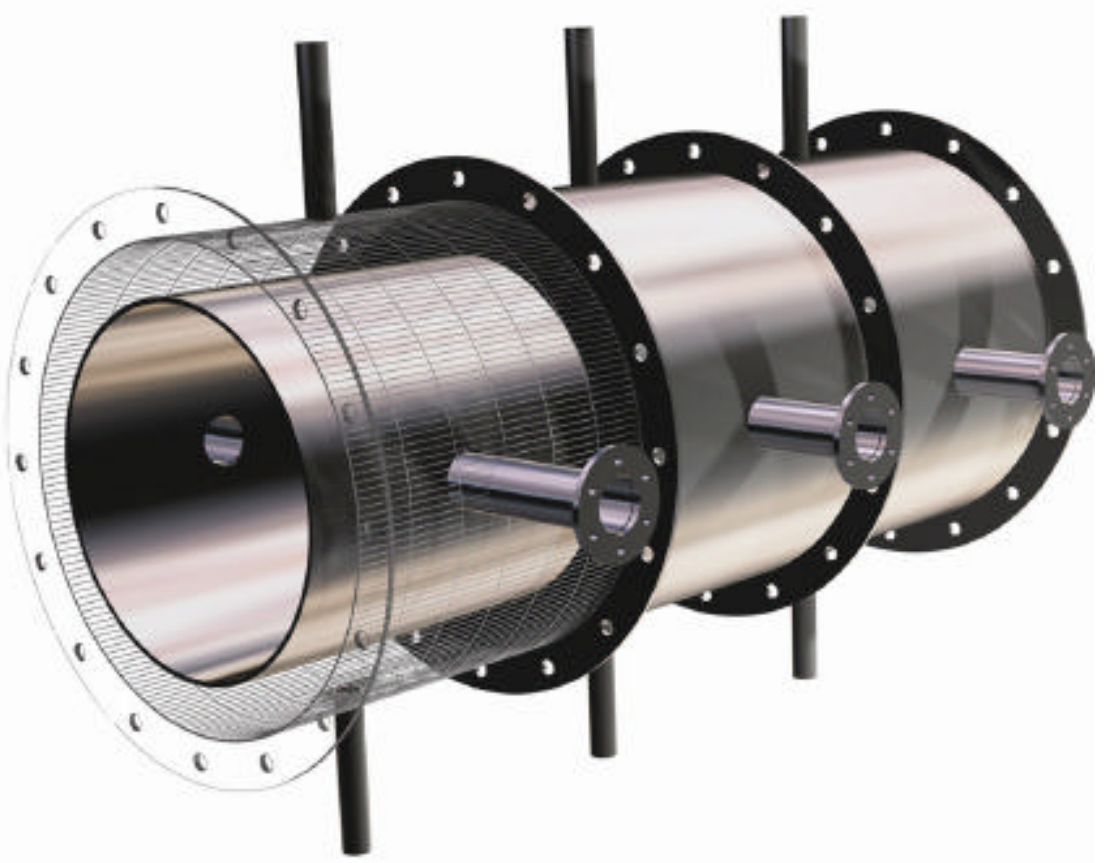

Figura 15 - Detalhamento construtivo da fornalha.

Cada módulo tem um comprimento de 1 metro e é constituído por um tubo central com diâmetro interno de $305 \mathrm{~mm}$, sobreposto por um outro tubo com diâmetro interno de $415 \mathrm{~mm}$, formando uma câmara de escoamento de água com espessura de 55 mm entre os dois tubos. O módulo, individualmente, é constituído por três câmaras calorimétricas de $328 \mathrm{~mm}$ de comprimento, ou seja, em cada um existe um par de flanges nas extremidades e dois flanges que subdividem o tubo externo e a câmara de água, formando assim as três câmaras calorimétricas. Os flanges internos são soldados sobre a face externa do tubo interno para promover estancamento entre as câmaras calorimétricas.

Cada câmara calorimétrica é atravessada por dois tubos com $25 \mathrm{~mm}$ de diâmetro interno, soldados um de cada lado, na mesma direção, para servirem de ponto de observação da chama e coleta de dados e amostras de gases. Além disso, cada câmara possui dois tubos de $19 \mathrm{~mm}$ de diâmetro interno, soldados na parte inferior e superior da 
câmara para servirem respectivamente para alimentação e descarga de água da câmara calorimétrica.

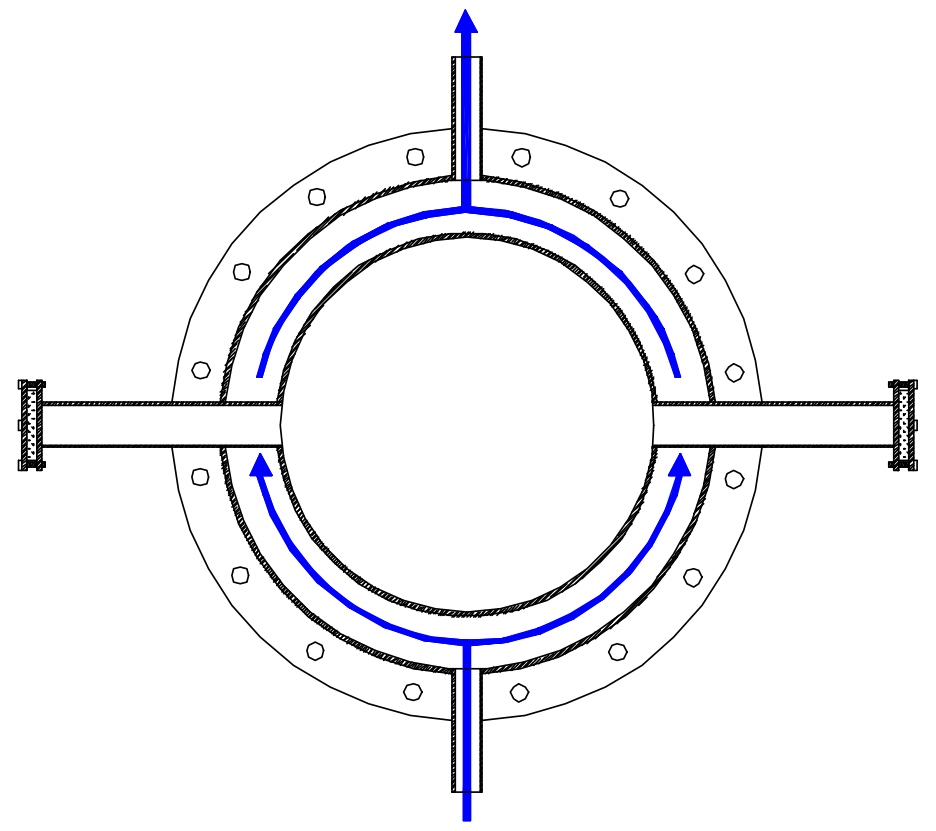

Figura 16 - Detalhe transversal da câmara de escoamento da água.

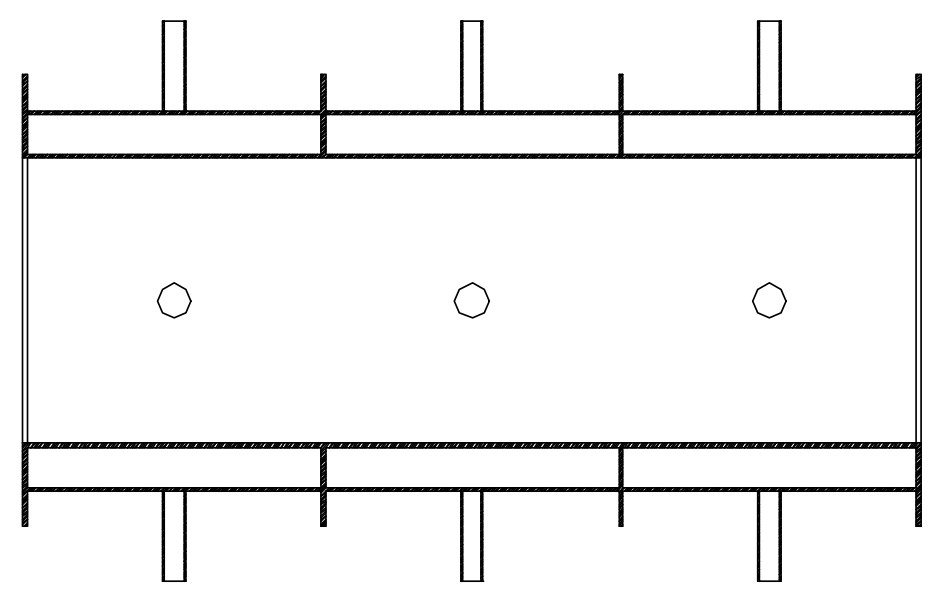

Figura 17 - Detalhe longitudinal de um módulo.

O tubo interno é de aço inox AISI 304, Sch10s. O tubo externo foi calandrado partindo-se de chapas de aço inox AISI $304 \mathrm{de} 2 \mathrm{~mm}$. Os flanges foram construídos partindo-se de chapas de aço inox AISI 304 de $5 \mathrm{~mm}$. Os tubos de observação e de água são de aço inox AISI 304, Sch5s.

Obs: A ASME VIII (section I - Power Boilers) foi consultada como orientação do projeto, contudo as espessuras adotadas não foram calculadas segundo as fórmulas estabelecidas pela norma pois as câmaras calorimétricas não têm a finalidade de gerar vapor. 


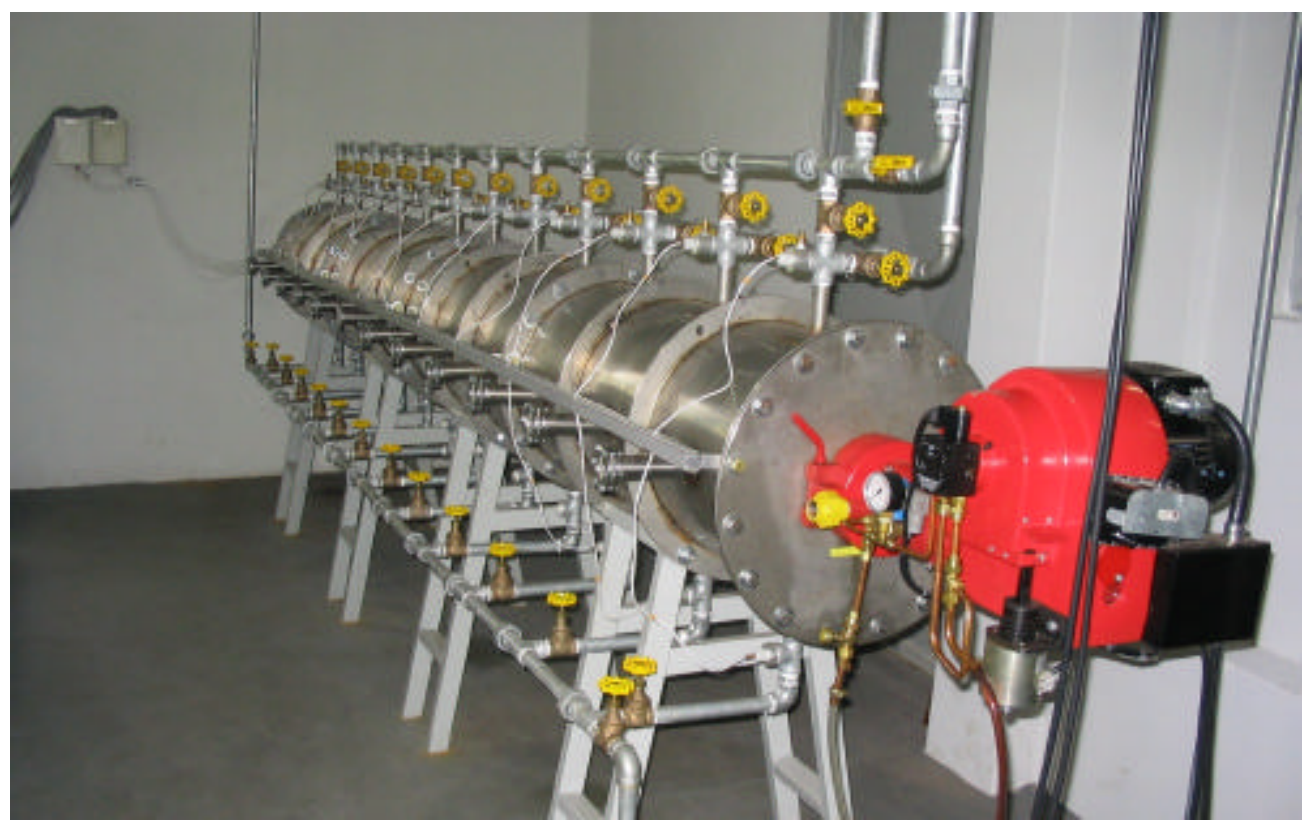

Fotografia 2 - Fornalha calorimétrica.

Os quatro módulos foram montados em série, apoiados em cavaletes de 1 metro de altura, feitos em perfil metálico de 40 × $20 \mathrm{~mm}$. Na parte frontal foi montado uma flange, onde foi instalado o suporte para receber o queimador.

\section{1 - Detalhamento do Queimador}

O queimador é de fabricação INCOETERMIC Ltda - Indústria e Comércio de Equipamentos Térmicos, e é do tipo monobloco para óleo e gás (Mod. SST 03 - D122 $U O P$ ) com capacidade para produzir $180.000 \mathrm{kcal}$. É dotado de um motor WEG de 200 V, trifásico, 2,39 A, $3.430 \mathrm{rpm}$ e 0,55 kW; ventilador do tipo Sirocco e bomba de óleo Danfoss Mod. BFP 21 L 5, que tem as seguintes características técnicas:

Tabela 4 - Características: Bomba de óleo.

\begin{tabular}{lr}
\hline Faixa de viscosidade do óleo & $1,8-12 \mathrm{~mm}^{2} / \mathrm{s}(\mathrm{cSt})$ \\
Velocidade & $1.400-3.600 \mathrm{rpm}$ \\
Faixa de pressão & $7-20 \mathrm{bar}$ \\
Faixa de temperatura & -10 a $70^{\circ} \mathrm{C}$ \\
\hline
\end{tabular}

A alimentação do óleo da bomba para o queimador, o retorno da bomba e o retorno do queimador pode ser observado na fotografia (2). A tomada do meio é para a alimentação de óleo do swirler do bico atomizador (mecânico) do queimador, esta linha 
de alimentação de óleo é comandada pelo solenóide preto situado no corpo da bomba. Quando o solenóide está aberto, alimenta-se de óleo o swirler de alimentação do bico atomizador. Quando o solenóide preto está fechado, o óleo de alimentação é interrompido e o fogo se apaga.

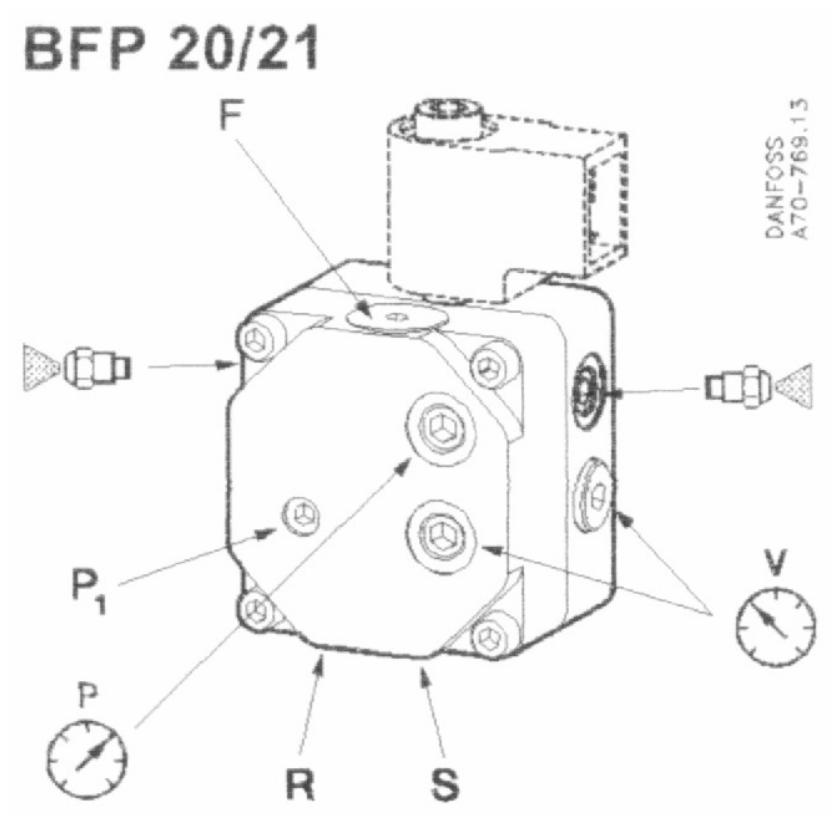

Figura 18 - Bomba de óleo Danfoss.

Sendo que, na figura (18): $\mathrm{P}_{1}$ é a regulagem de pressão, $\mathrm{P}$ é o ponto para instalação de manômetro, $\mathrm{R}$ é o retorno de óleo da bomba, devido ao alívio do regulador de pressão, $\mathrm{S}$ é a entrada de óleo na bomba, V são os pontos para instalação de vacuômetro para avaliar a sucção, F é o alojamento do filtro tipo cartucho, e os Bicos atomizadores ilustrados são pontos para tomada de óleo para alimentação do swirler do bico atomizador.

O queimador também é dotado de um solenóide que abre e fecha uma borboleta de ar em função do comando de fogo alto e fogo baixo. Quando o solenóide azul é desligado, interrompe-se o retorno de óleo do swirler e mais óleo é debitado pelo bico atomizador; nesse instante o solenóide de ar é acionado abrindo mais a borboleta de ar para suprir o ar necessário em condição de fogo alto. O queimador também possui um pressostato de pressão de ar para a monitoração do funcionamento do ventilador soprador.

$\mathrm{O}$ queimador possui um transformador que é alimentado com $220 \mathrm{~V}$ e transforma essa tensão em $11.000 \mathrm{~V}$ para alimentar os eletrodos de ignição, durante a 
partida. No interior do queimador monobloco existe uma célula fotovoltaica que avisa ao módulo de comando da combustão se existe fogo ou não no interior da fornalha. Através da célula fotovoltaica o comando identifica se a ignição foi bem sucedida ou não. Em caso positivo, os eletrodos de ignição são desligados; em caso negativo, o processo de combustão é abortado e um alarme é disparado indicando falta de chama. O operador deve verificar qual é o problema, corrigi-lo e reiniciar a operação de partida. Falha de partida geralmente ocorre devido ao acúmulo de óleo não queimado sobre os isoladores dos eletrodos de ignição ou ainda devido à trinca nesses isoladores. Outra causa freqüente de falha é a falta de óleo ou entupimento em algum ponto do circuito de óleo (filtro, bico atomizador).

\section{2 - Sistema de aquisição de temperaturas com termopar}

Neste sistema, foram confeccionados termopares do tipo $K$ e utilizou-se um sistema de aquisição de dados composto por um microcomputador, uma placa $A D$ STRAWBERRY TREE 12 bit de 16 canais e um terminal de compensação T-21 STRAWBERRY TREE de 8 canais.

O sistema é uma ferramenta versátil, e de fácil utilização, possuindo como característica principal a alta rejeição a ruídos. Utiliza-se um pacote computacional aplicativo, WORKBENCH, que permite o tratamento do sinal medido através de diversas funções matemáticas. Além disso, o próprio sistema realiza eletronicamente a compensação da junção fria e a linearização do sinal.

Foram construídos 14 termopares tipo K (níquel - cromel) de um comprimento de 10 m cada um. A união dos termopares foi soldada sob gás inerte, néon, em um equipamento construído no laboratório para este fim.

Para a calibração dos termopares utilizou-se um banho termostático, que trata-se de um equipamento cuja função é manter a temperatura de uma solução líquida uniforme e estável dentro de uma faixa desejada de temperatura. Para isso utiliza um sistema de aquecimento e um de resfriamento controlado por um circuito PID (Proportional Interactive Derivative).

Para obter uma leitura da temperatura de referência utilizou-se um termômetro de bulbo de mercúrio, escala interna de 0 a $100{ }^{\circ} \mathrm{C}$ com mínima divisão de escala $0,2{ }^{\circ} \mathrm{C}$ 
e de capilar prismático azul para facilitar a leitura com certificado de calibração (incerteza $= \pm 0.05^{\circ} \mathrm{C}$ ).

\section{3 - Câmaras Calorimétricas}

A fornalha é dividida em quatro módulos sendo que cada um deles possui três câmaras calorimétricas como pode ser visto na fotografia (3) a seguir:

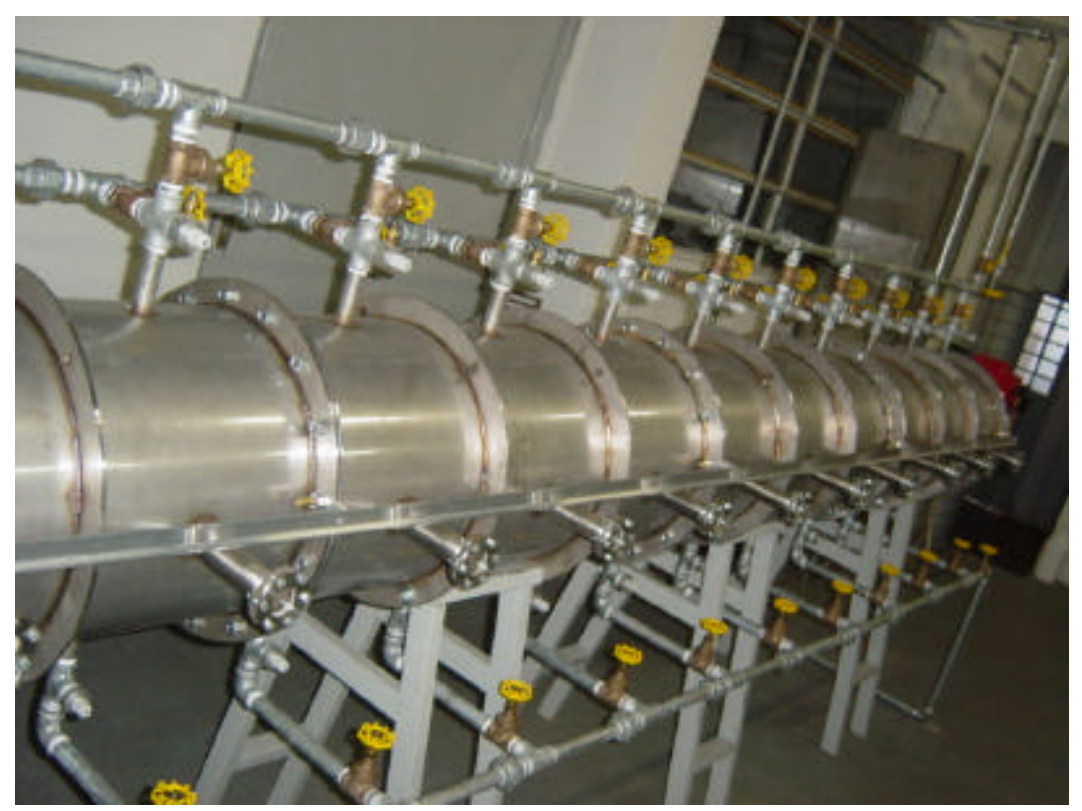

Fotografia 3 - Vista das câmaras calorimétricas.

A fornalha tem o suprimento de água através de um sistema de bombeamento que tem capacidade de fornecer até 5.000 litros por hora. A vazão de água em cada célula calorimétrica é controlada manualmente através de registros instalados na entrada de água (pela parte inferior) e por registros instalados na saída de água de cada câmara calorimétrica (pela parte superior). Na parte superior a água de saída pode ser dirigida para a caixa de armazenamento de água com capacidade de 3.000 litros ou para o sistema de medida de vazão de água. Este direcionamento da descarga da água de saída é controlado manualmente através de dois registros instalados na saída de cada câmara calorimétrica.

A água do sistema de armazenamento é bombeada para um sistema de dissipação de calor através de torres de resfriamento evaporativo com a finalidade de manter a temperatura de alimentação aproximadamente constante. Na fotografia (4) é 
possível ver duas bombas instaladas ao lado do depósito de 3.000 litros. Uma bomba manda água para os calorímetros da fornalha. A outra bomba manda água para um sistema de três torres de resfriamento evaporativo (fotografia 5) que também tem capacidade de armazenamento de 3.000 litros, constituindo-se em um sistema de armazenamento e resfriamento evaporativo de água em circuito fechado. Esta é uma infra-estrutura preciosa para os experimentos na área térmica pois permite a troca de calor com baixíssimo consumo de água.

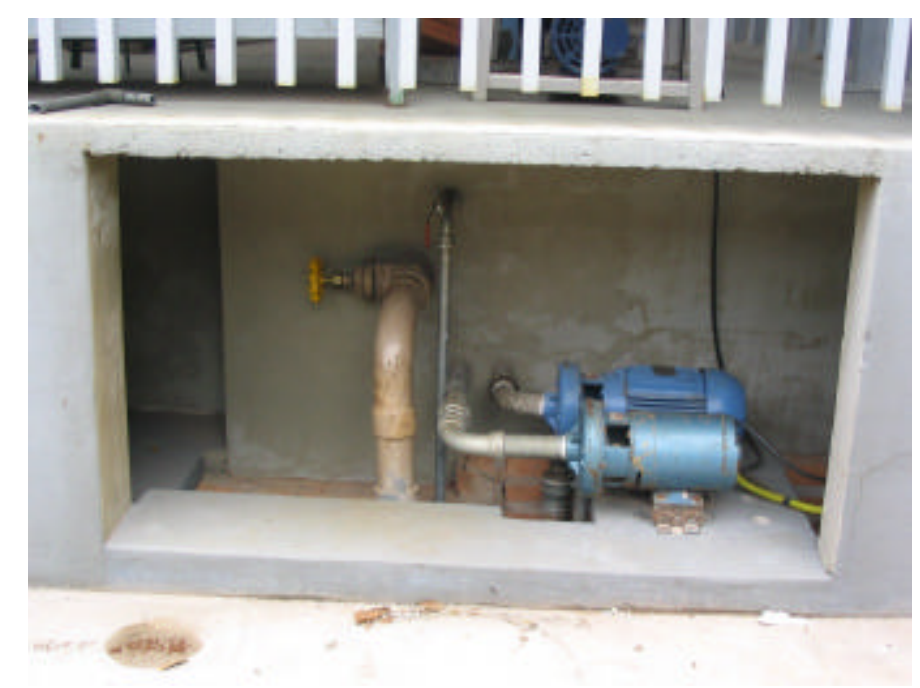

Fotografia 4 - Sistema de bombeamento de água.

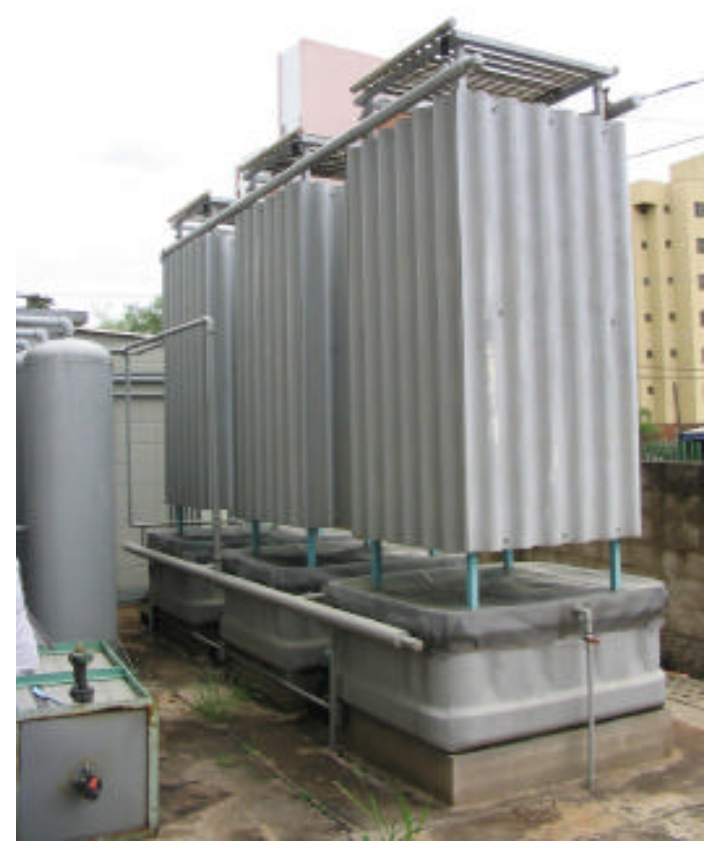

Fotografia 5 - Sistema de resfriamento evaporativo da água armazenada. 
O sistema de medida da vazão de água através de cada câmara calorimétrica é constituído por um rotâmetro e um depósito de sessão retangular em vidro, ligados em série. O depósito de secção retangular em vidro é dotado de uma escala graduada que permite a medição da descarga de água e, por conseguinte permite aferir o rotâmetro (ver fotografia 6 e Anexo V).

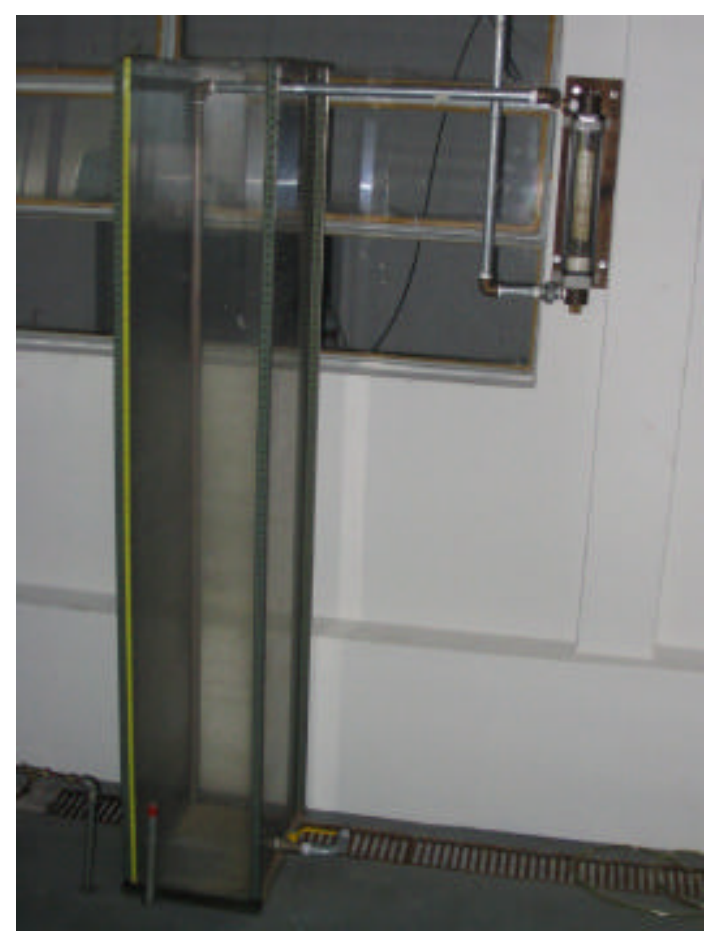

Fotografia 6 - Depósito de secção retangular com escala e rotâmetro para medição da vazão de água.

\section{4 - Consumo de Combustível}

O sistema de fornecimento de combustível é constituído por um tanque de 60 litros e uma linha em tubo de cobre onde foram instalados uma bureta graduada para medida do consumo de combustível com o auxilio de um cronômetro, como pode ser visto na fotografia (7). Para que o erro experimental não se tornasse excessivo, fizeramse várias medidas de tempo, extraindo-se assim uma média das medidas realizadas. 


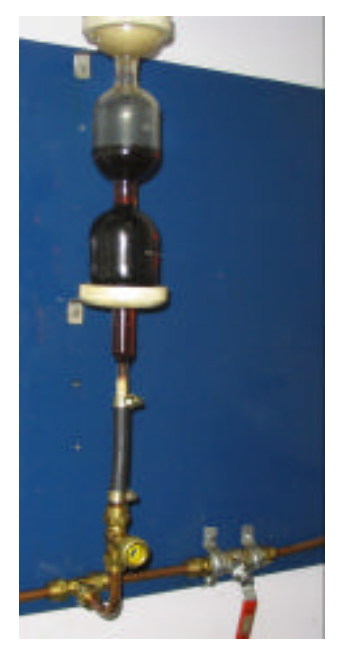

Fotografia 7 - Linha de combustível: bureta graduada.

\section{5 - Descarga dos Gases de Combustão}

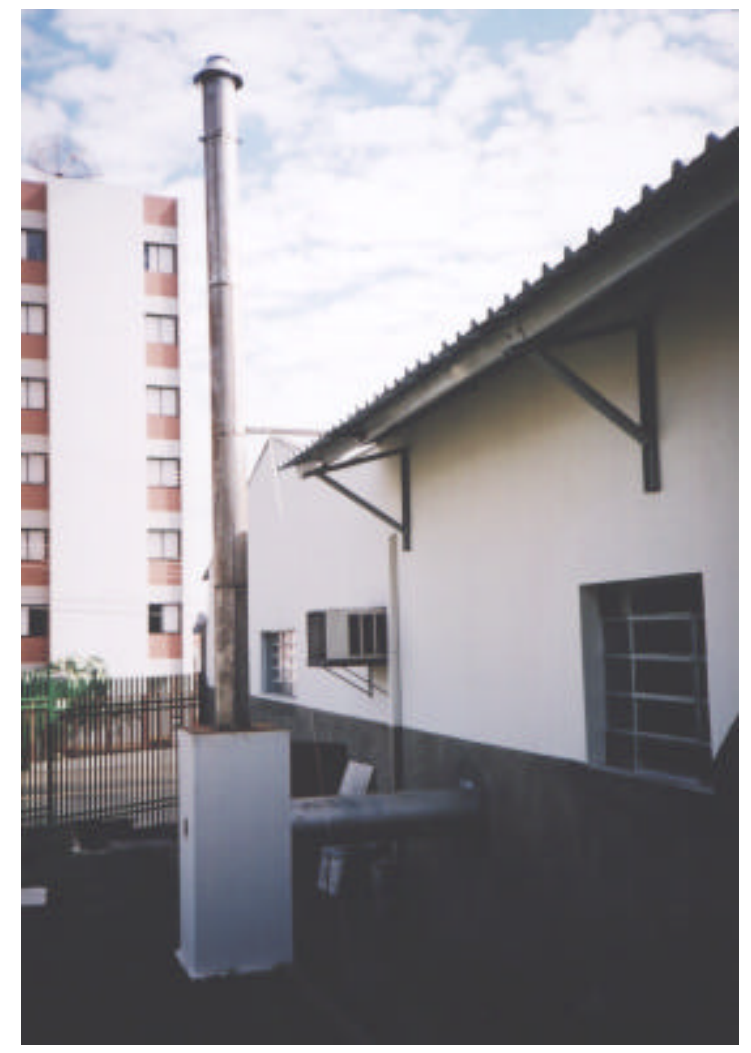

Fotografia 8 - Chaminé.

Para a descarga de gases foi feito um prolongamento da fornalha de 1,60 m, em aço carbono, que descarrega os gases em na base da chaminé (fotografia 8) feito em alvenaria com secção interna quadrada de 0,40 x 0,40 m e 1,40 m de altura. Esta base é 
dotada de uma espia para verificação da chama. Sobre a base, foi erguida a chaminé com 0,20 m de diâmetro interno e $4 \mathrm{~m}$ de altura.

\section{6 - Diagrama Esquemático}

Com o propósito de facilitar o entendimento da bancada experimental, na figura (19) é mostrado um diagrama esquemático com as referidas partes identificadas com legendas.

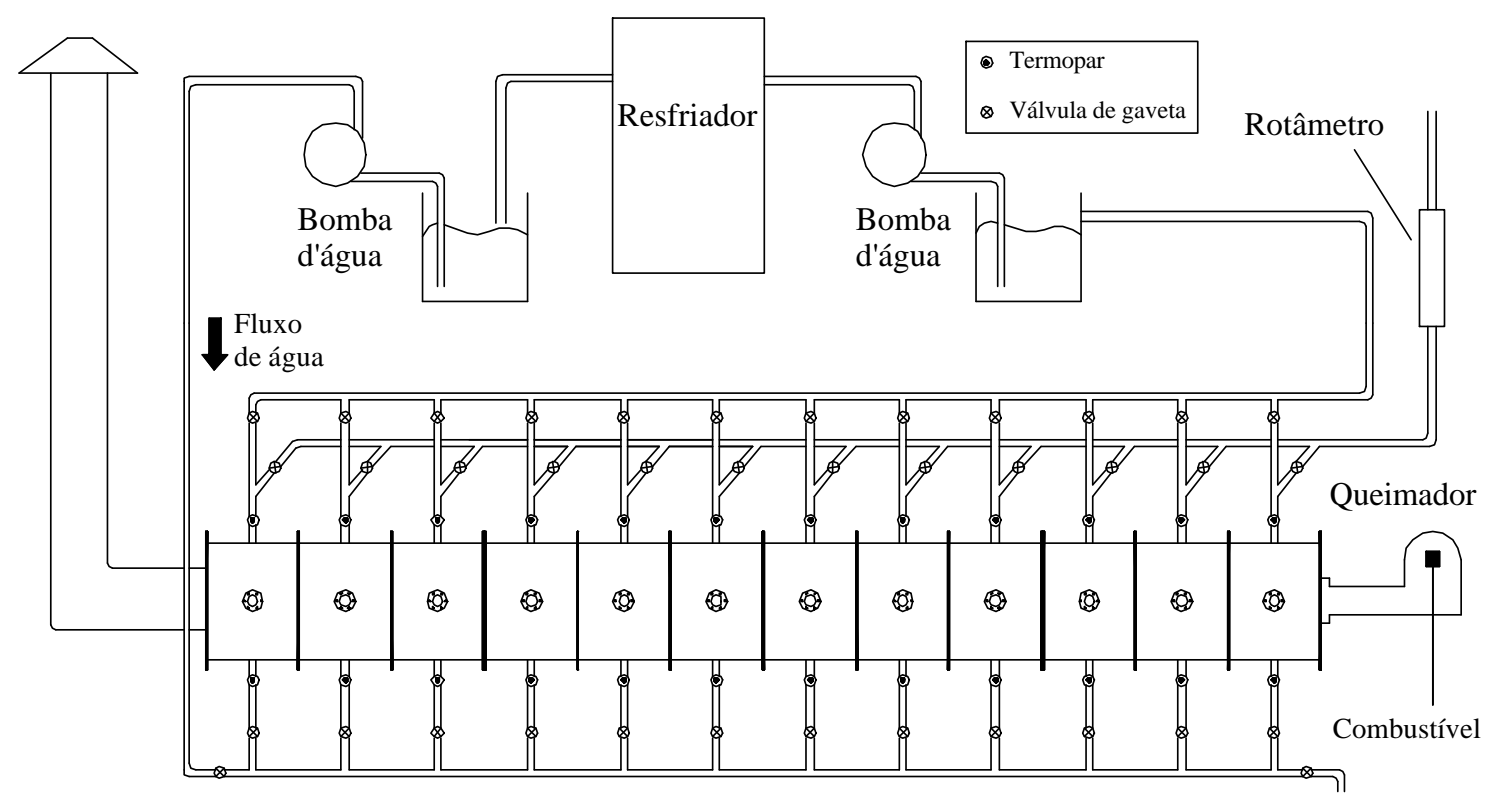

Figura 19 - Esquema da bancada experimental.

\section{7 - Metodologia utilizada para a variação do Fator de Excesso de Ar}

Como já foi descrito anteriormente, o queimador utilizado possui uma bomba responsável pela sucção e injeção do combustível acoplado em seu corpo. Esta bomba possibilita uma variação na quantidade de combustível injetado na câmara de combustão através da pressão de injeção. Fixando-se a abertura da borboleta de entrada de ar, obtém-se uma gama de razões ar/combustível. 


\section{8 - Temperatura de Chama}

A temperatura de chama é um fator importante para se avaliar a transferência de calor em uma fornalha. Esta temperatura varia de acordo com a razão ar/combustível (A/C) estabelecida para a combustão.

Para se obter a temperatura de chama foi utilizado um pirômetro manual infravermelho Ursatherm ${ }^{\circledR}$ - Pyrovar $H P H$, que tem capacidade de medir temperaturas que variam entre $600-1400{ }^{\circ} \mathrm{C}$ e $800-2000{ }^{\circ} \mathrm{C}($ erro $=1 \%)$. A emissividade da chama foi fixada em 0,95, como sugerido para a chama da nafta por Annaratone (1968).

\section{9 - Analisador de Gases}

O analisador de gases infravermelho TM 131 utilizado possui uma célula eletroquímica para medição das concentrações de $\mathrm{CO}, \mathrm{CO}_{2}$ e $\mathrm{O}_{2}$. Para as medições de $\mathrm{NO}_{\mathrm{x}}$ aplica-se uma célula eletrônica. $\mathrm{O}$ analisador foi calibrado com propano $\left(\mathrm{C}_{3} \mathrm{H}_{8}\right)$, e a aferição do aparelho foi realizada no laboratório de motores, com uma garrafa de 1600 ppm de NO e outra de 4\% de CO, fornecidas pela WHITE-MARTINS Gases Industriais S/A com certificado de aferição e garantia de 60 meses (MARTINS, 2003). A medida ilustrada no visor de THC, fornecida em ppm, deve ser multiplicada por dois para obter uma estimativa da atual concentração dos hidrocarbonetos.

As principais precauções a serem tomadas no manuseio do analisador de gases, ver fotografia (9), antes das medições devem ser:

- Checar a condensação de água nas mangueiras, aspirando-as sempre para cada bateria realizada, evitando assim possíveis erros de medição.

- Checar a existência de entradas de ar falsas, para evitar diluição da mistura.

- Supervisionar o filtro do analisador e trocá-lo periodicamente.

- Não utilizar mangueiras de teflon, pois apresentam concentrações de THC. 


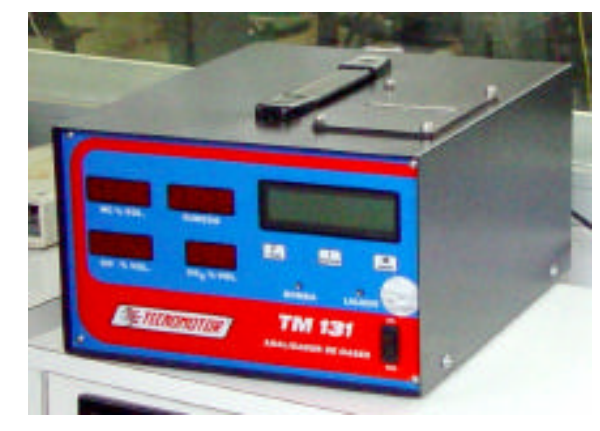

Fotografia 9 - Analisador de Gases de Exaustão.

Fonte: Martins (2003).

\subsection{0 - Caracterização dos Combustíveis}

\subsection{1 - Poder Calorífico Superior}

Conforme visto no item 3.1.1, determinou-se o poder calorífico superior dos combustíveis utilizados no experimento através de bomba calorimétrica adquirida por nosso laboratório, Núcleo de Engenharia Térmica e Fluidos - NETeF, com apoio do Conselho Nacional de Desenvolvimento Científico e Tecnológico - CNPq, Processo $\mathrm{N}^{\circ}$ 460283/01-4. Os resultados podem ser observados na tabela (5).

\subsection{2 - Massa Específica}

Utilizou-se uma balança com duas casas de precisão, em gramas, e uma bureta graduada em mililitros para determinar a densidade dos combustíveis queimados na fornalha. A temperatura dos combustíveis também foi obtida, sendo que esta serve de parâmetro para se identificar a densidade dos fluidos desejados. Os valores obtidos são mostrados na tabela (5).

\subsection{3 - Viscosidade Dinâmica}

Somente a massa específica não é suficiente para se caracterizar um fluido. Dois fluidos podem possuir massas específicas aproximadamente iguais e descreverem comportamentos diferentes em uma condição de escoamento. De acordo com a Lei da Viscosidade de Newton, a relação entre a tensão de cisalhamento do fluido e a sua taxa de deformação é dada por: 


$$
\tau=\mu \frac{d u}{d y}
$$

Onde $t$ é a tensão de cisalhamento $\left[\mathrm{N} \mathrm{m}^{-2}\right], \mu$ é a viscosidade dinâmica $\left[\mathrm{N} \mathrm{s} \mathrm{m}^{-2}\right]$ e $d u / d y$ é a taxa de deformação $\left[\mathrm{s}^{-1}\right]$.

A viscosidade é medida em viscosímetros, os quais podem ser classificados em dois grupos: primários e secundários. No grupo primário estão os instrumentos que realizam medidas diretas de tensão de cisalhamento e taxa de deformação do fluido. Os viscosímetros do grupo secundário indicam a razão entre a tensão e a taxa de deformação indiretamente. Nesta categoria estão os viscosímetros capilar, no qual a viscosidade é obtida por meio da medida do gradiente de pressão de um escoamento laminar em um tubo, e o viscosímetro de Stokes, onde se determina a viscosidade do fluido através da medida do tempo de queda livre de uma esfera no fluido.

Utilizou-se o Reômetro Digital - Brookfield para a obtenção direta da viscosidade dinâmica dos combustíveis analisados. A concepção do aparelho consiste na reprodução do escoamento entre placas planas paralelas, podendo ser utilizados vários pêndulos de acordo com a viscosidade do fluido, pêndulo com menor diâmetro para maiores viscosidades e pêndulo com maior diâmetro para menores viscosidades.

O aparelho nos fornece a planilha do referido teste efetuado, com os resultados das viscosidades de acordo com a rotação do pêndulo. Como a viscosidade varia conforme a rotação, torna-se necessário uma analise das curvas obtidas no gráfico: Tensão de Cisalhamento versus Taxa de Deformação. A viscosidade $(\mu)$ é encontrada através da inclinação da reta obtida e é expressa em [Poise] ou [ $\left.\mathrm{N} \mathrm{s} \mathrm{m}^{-2}\right]$. 


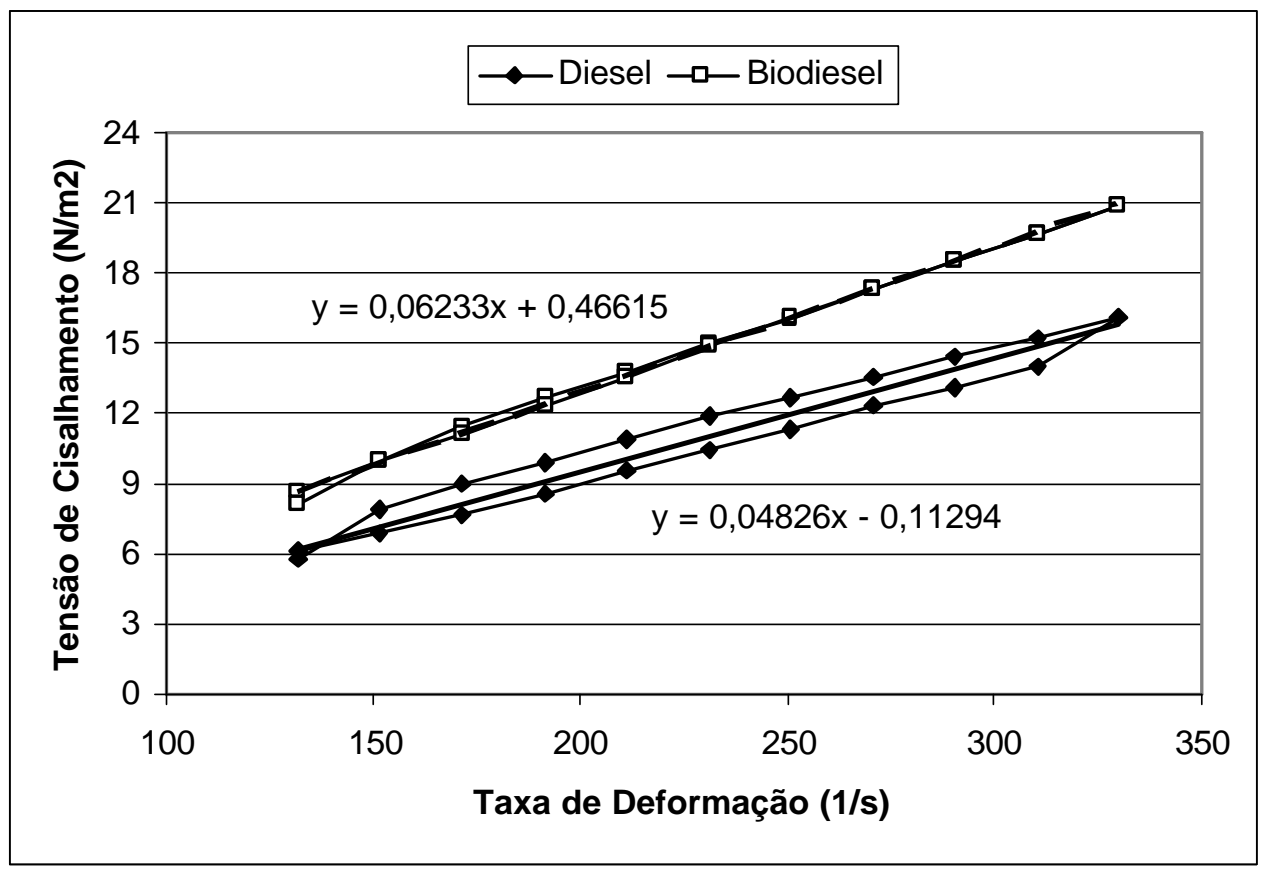

Gráfico 1 - Viscosidade Dinâmica do Óleo Diesel $\left(26,1^{\circ} \mathrm{C}\right)$ e $\operatorname{Biodiesel~}\left(25,6^{\circ} \mathrm{C}\right)$.

No gráfico (1), pode-se notar um comportamento diferenciado para o combustível diesel, à medida que a rotação do pêndulo aumenta, a tensão de cisalhamento e taxa de deformação observadas também aumentam. Este comportamento diretamente proporcional se mantém quando o caminho inverso de diminuição da rotação é efetuado, porém com valores diferentes de tensão de cisalhamento e taxa de deformação. Note que para o calculo da viscosidade este efeito não influencia nos resultados, pois os dois caminhos assumidos pelo fluido demonstram, aproximadamente, uma mesma inclinação da reta.

\subsection{4 - Características dos Combustíveis}

$\mathrm{Na}$ tabela (5), observa-se as características dos combustíveis utilizados no experimento, as análises foram realizadas no Núcleo de Engenharia Térmica e Fluidos da Escola de Engenharia de São Carlos.

Tabela 5 - Características dos Combustíveis: Óleo Diesel e Biodiesel de Óleo de Fritura.

\begin{tabular}{lcc}
\hline Características & Diesel & Biodiesel \\
\hline Poder calorífico superior $(\mathrm{kJ} / \mathrm{kg})$ & 44815 & 39622 \\
Massa específica $-25^{\circ} \mathrm{C}\left(\mathrm{kg} / \mathrm{m}^{3}\right)$ & 857 & 872 \\
Viscosidade dinâmica $(\mathrm{cP})$ & $4,826\left(26,1^{\circ} \mathrm{C}\right)$ & $6,233\left(25,6^{\circ} \mathrm{C}\right)$ \\
\hline
\end{tabular}




\section{5 - RESULTADOS E DISCUSSÕES}

\section{1 - Emissões}

Os resultados obtidos através da combustão dos combustíveis, Óleo Diesel e Biodiesel, variando-se o fator de excesso de ar, são apresentados nos gráficos (2), (3) e (4) na forma de percentual de $\mathrm{CO}_{2}$ e $\mathrm{O}_{2}$, e partes por milhão (ppm) de THC. É importante salientar que as análises de gases foram feitas em uma única tomada de gases situada a uma distância de queimador igual a $345 \mathrm{~cm}$, para as situações observadas no experimento.

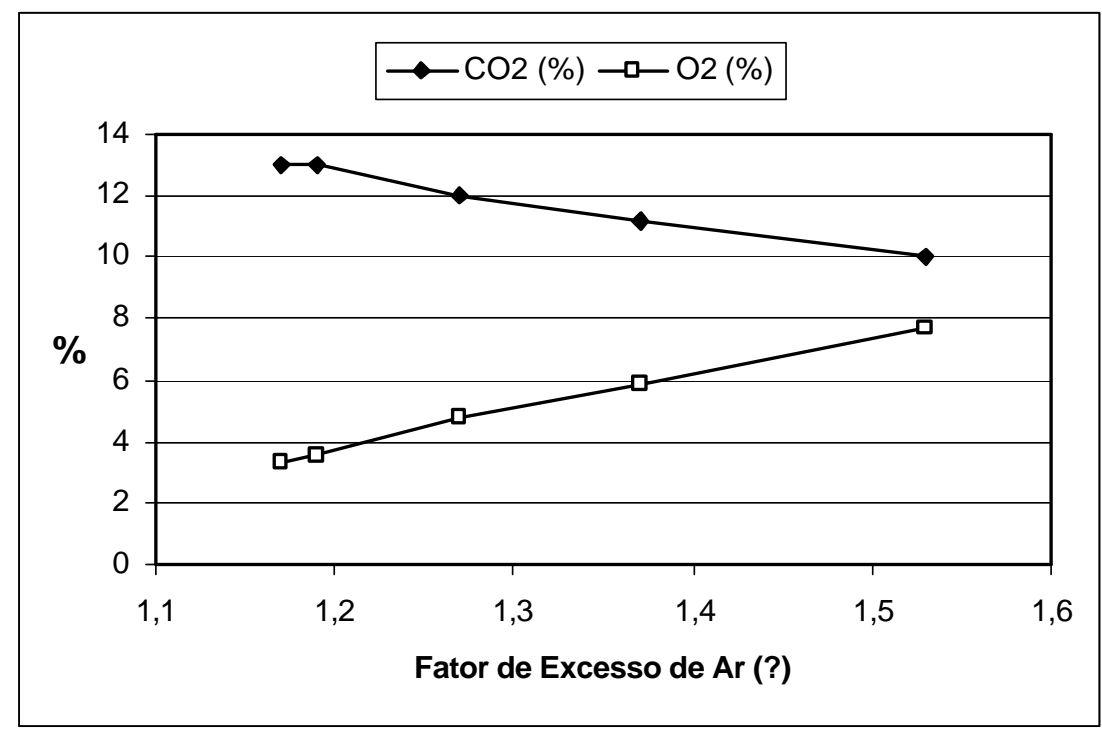

Gráfico 2 - Gases de Exaustão obtidos com a combustão do Óleo Diesel.

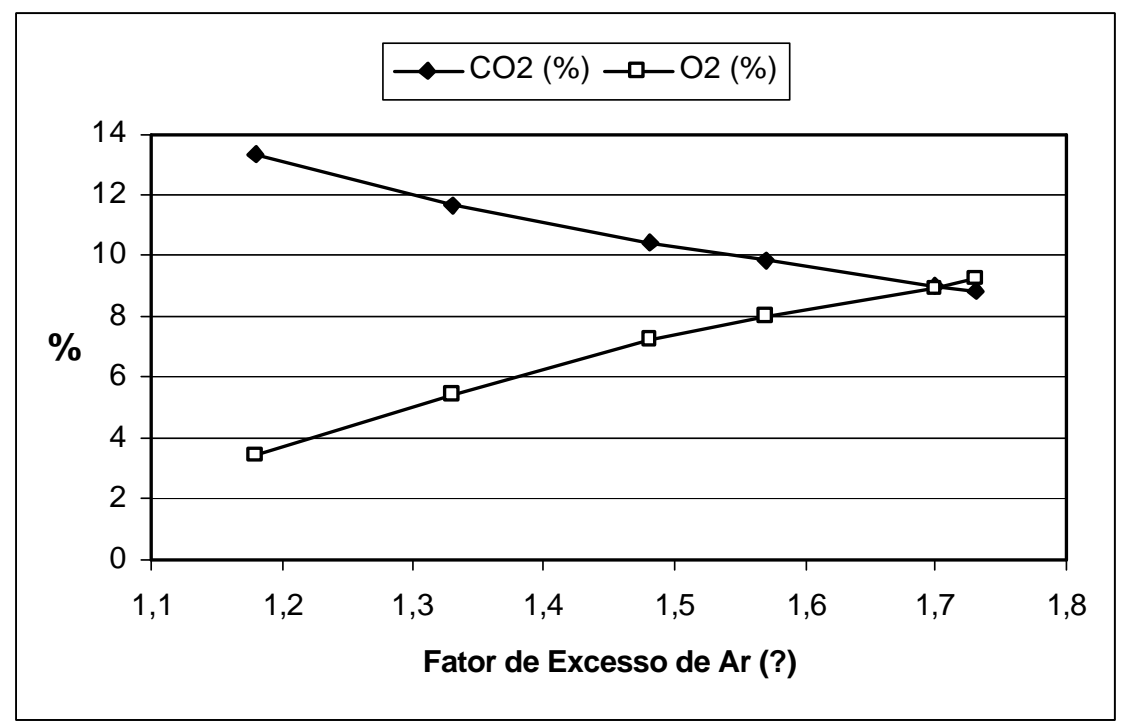

Gráfico 3 - Gases de Exaustão obtidos com a combustão do Biodiesel. 


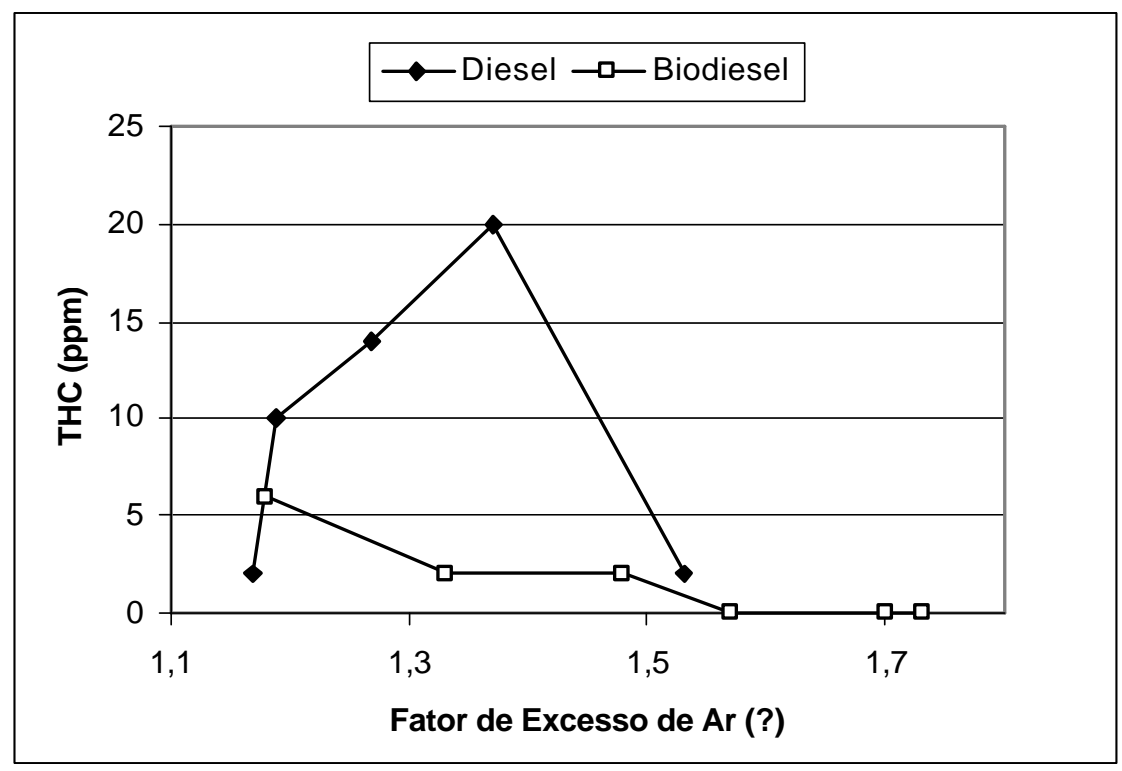

Gráfico 4 - Total de Hidrocarbonetos (em ppm) na combustão do Óleo Diesel e Biodiesel.

À medida que o fator de excesso de ar aumenta, observa-se nos gráficos (2) e (3) que ocorreu uma elevação no percentual de oxigênio nos gases de escape, para ambos os combustíveis utilizados. Isso acontece pois o excesso de ar é elevado e a quantidade de oxigênio necessário para uma combustão completa já foi atingido com valores menores que ? igual a 1,2. Analisando as concentrações de $\mathrm{CO}_{2}$, de acordo com o aumento do fator de excesso de ar, nota-se que a curva tem um comportamento descendente devido a falta de CO nesta faixa de operação e conseqüente diluição de $\mathrm{CO}_{2}$.

As curvas de concentrações de THC no gráfico (4), com o aumento do fator de excesso de ar, indicam concentrações baixas para ambos os combustíveis, sendo que na queima do óleo diesel obtiveram-se níveis muito mais elevados, comparando-se ao biodiesel.

Os resultados obtidos das concentrações de $\mathrm{NO}_{\mathrm{x}}$ apresentaram níveis muito baixos, mantendo-se para o óleo diesel abaixo de 55 ppm e para o biodiesel abaixo de $30 \mathrm{ppm}$. Para o CO, os níveis mantiveram-se inferiores a $100 \mathrm{ppm}$ para ambos os combustíveis.

\section{2 - Taxa de Fluxo de Massa}

A taxa de fluxo mássico dos gases de exaustão $(G)$ é determinada através da expressão: 


$$
G=\frac{(A / C+1) \dot{m}_{c}}{\pi D_{f}^{2} / 4} \quad\left[k g m^{-2} s^{-1}\right]
$$

Onde $A / C$ é a razão ar/combustível, $\dot{m}_{c}$ é a vazão mássica de combustível [ $\mathrm{kg}$ $\mathrm{s}^{-1}$ ] e $D_{f}$ é o diâmetro da fornalha [ $\left.\mathrm{m}\right]$.

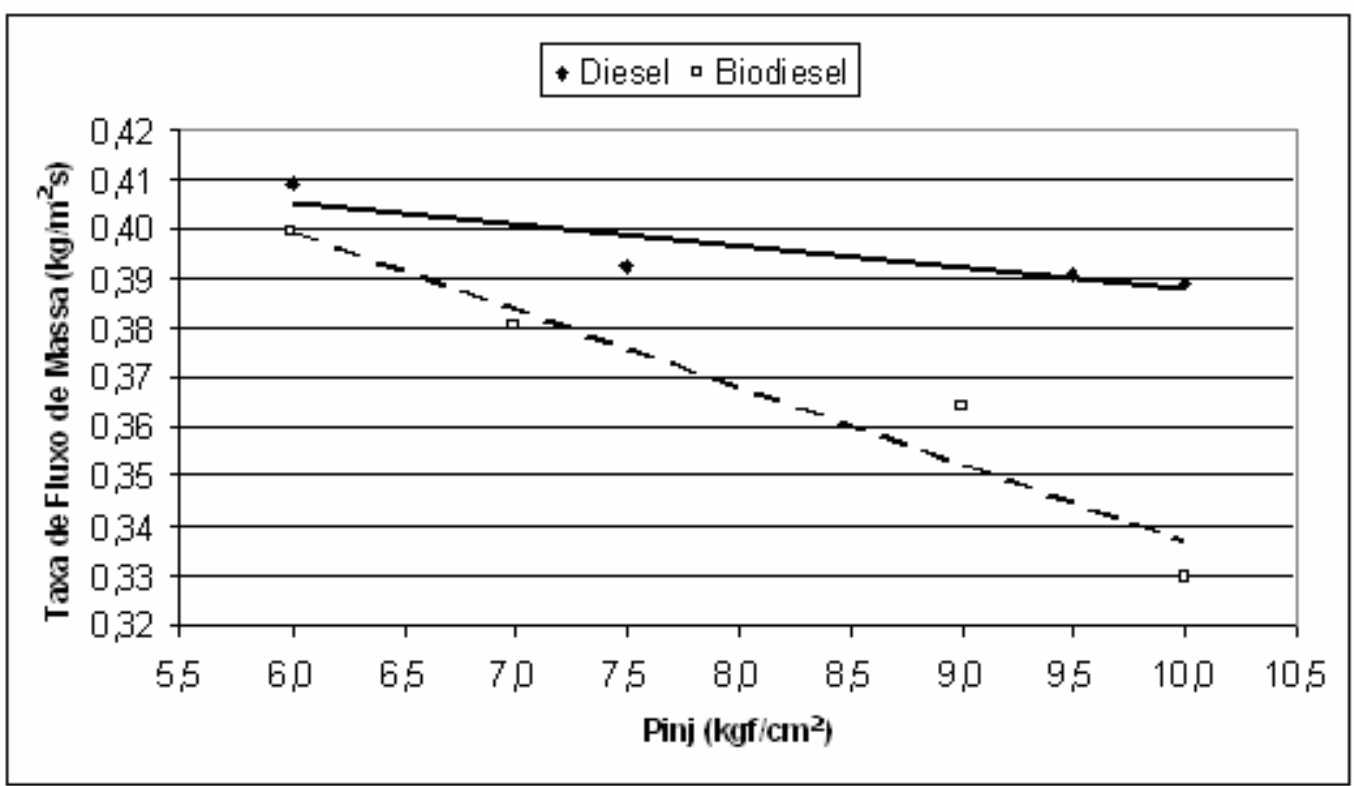

Gráfico 5 - Taxa de Fluxo Mássico dos Gases de Exaustão x Pressão de Injeção de Combustível.

Segundo Gunn e Horton (1989), a taxa $(G)$ na saída da fornalha deve ser de no máximo $2 \mathrm{~kg} \mathrm{~m}^{-2} \mathrm{~s}^{-1}$, e pode-se observar através do gráfico (5) que no experimento realizado obtiveram-se valores inferiores aos indicados pela literatura para ambos os combustíveis utilizados. Pôde-se observar também que os valores obtidos com a combustão do biodiesel são inferiores em relação ao óleo diesel, isso devido à densidade dos combustíveis próximas uma da outra e a viscosidade de cada combustível serem bem diferentes.

\section{3 - Rendimento Térmico da Fornalha}

$\mathrm{Na}$ bancada experimental, foi possível observar a transferência de calor nas diferentes células ao longo da fornalha, isso pode ser visto nos gráficos (6) e (7), onde 
estão "plotados" os percentuais de energia calorífica transferidos em cada célula calorimétrica em função da energia introduzida na fornalha e pressão de injeção dos combustíveis utilizados. Nota-se que nas células em que a chama está presente, a transferência de calor na combustão do óleo diesel é superior a do biodiesel. Nas regiões em que a chama já se extinguiu, o biodiesel demonstrou melhor transferência de calor nas células 7 e 6 , para pressão de injeção igual a $7 \mathrm{kgf} \mathrm{cm}^{-2}$.

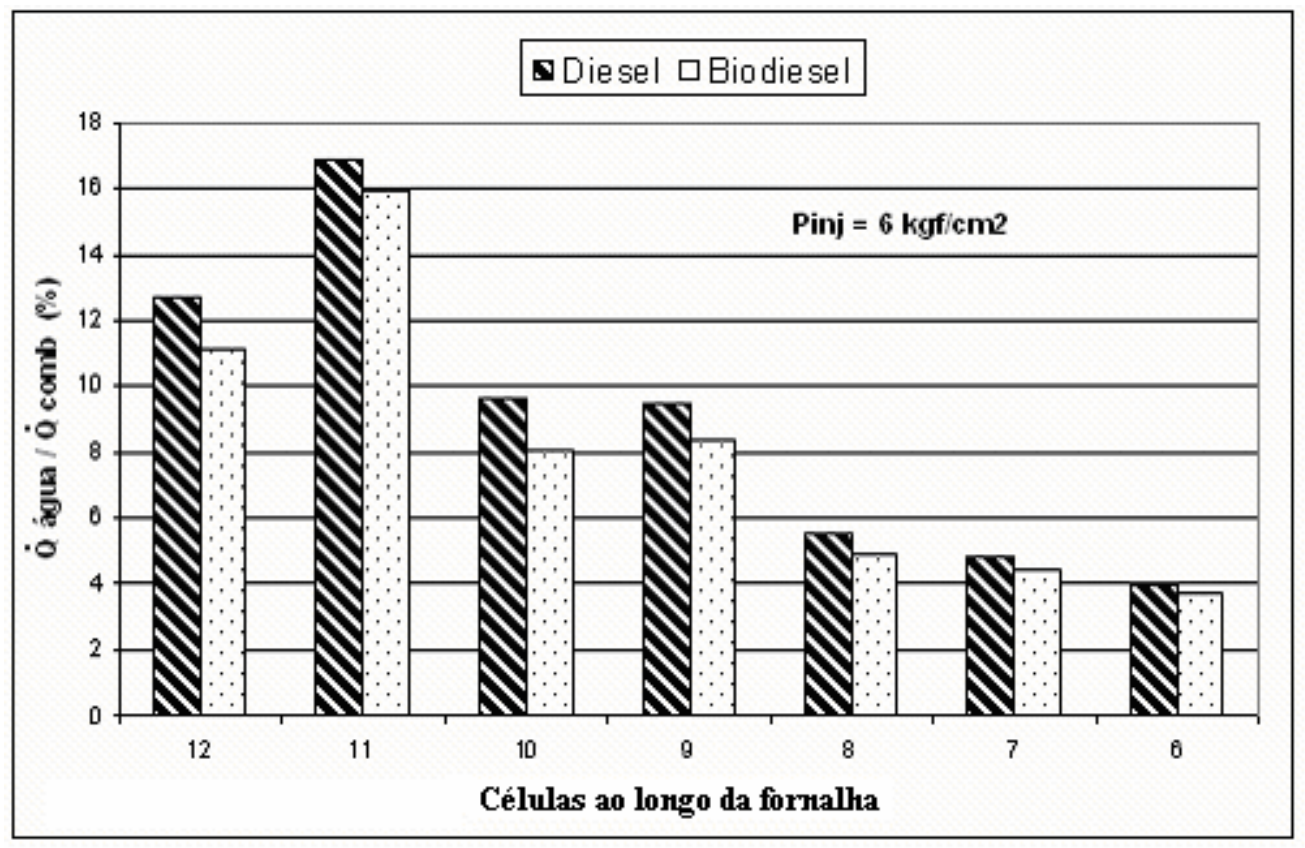

Gráfico 6 - Transferência de Calor na Fornalha (Pinj - 6 kgf cm²).

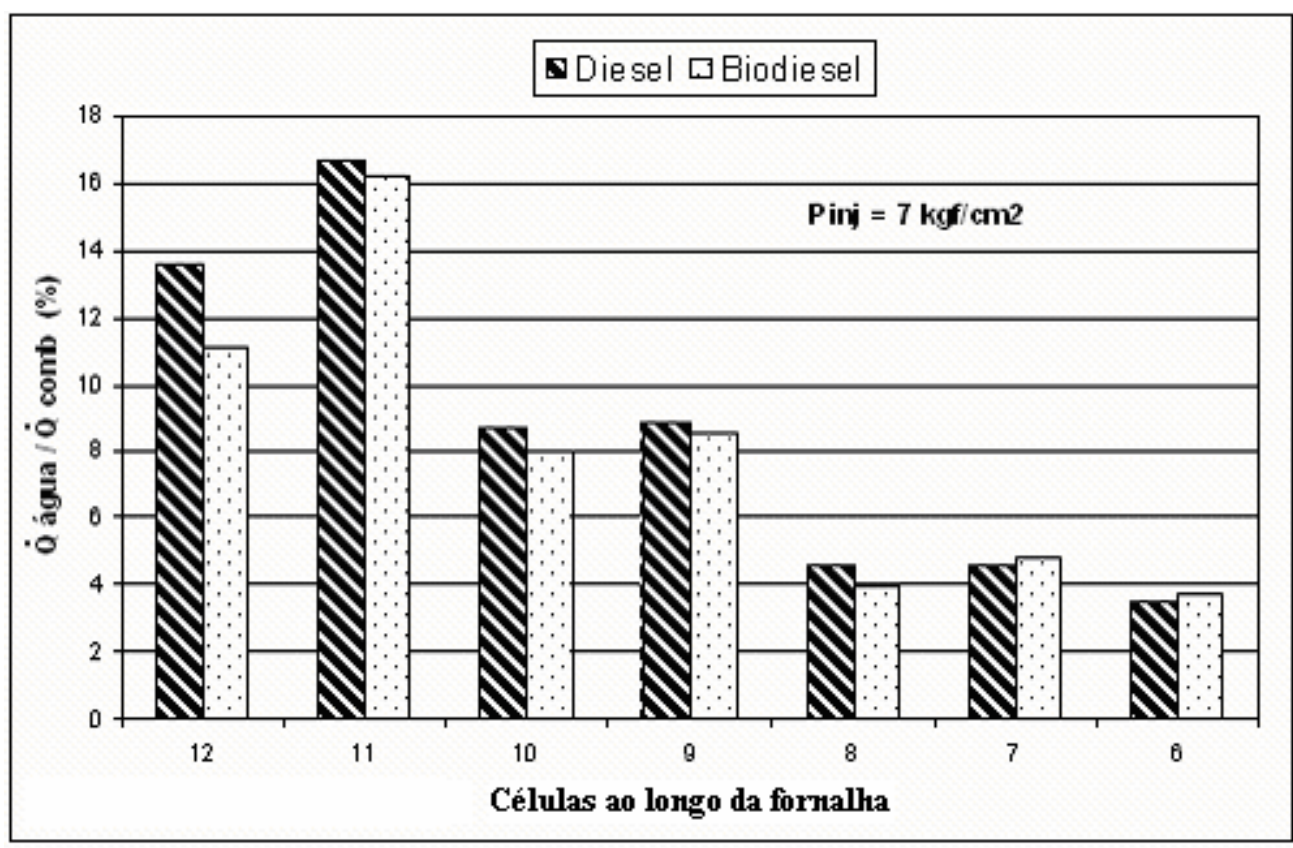

Gráfico 7 - Transferência de Calor na Fornalha (Pinj - 7 kgf cm $\mathbf{~ c m}^{-2}$. 
Conforme foi explanado no item 3.4, adquiriram-se os resultados experimentais e foi calculado o rendimento térmico da fornalha. Os gráficos mostram a diferença entre óleo diesel e biodiesel sob processo de combustão com 6 e $7 \mathrm{kgf} \mathrm{cm}^{-2}$ de pressão de injeção de combustível.

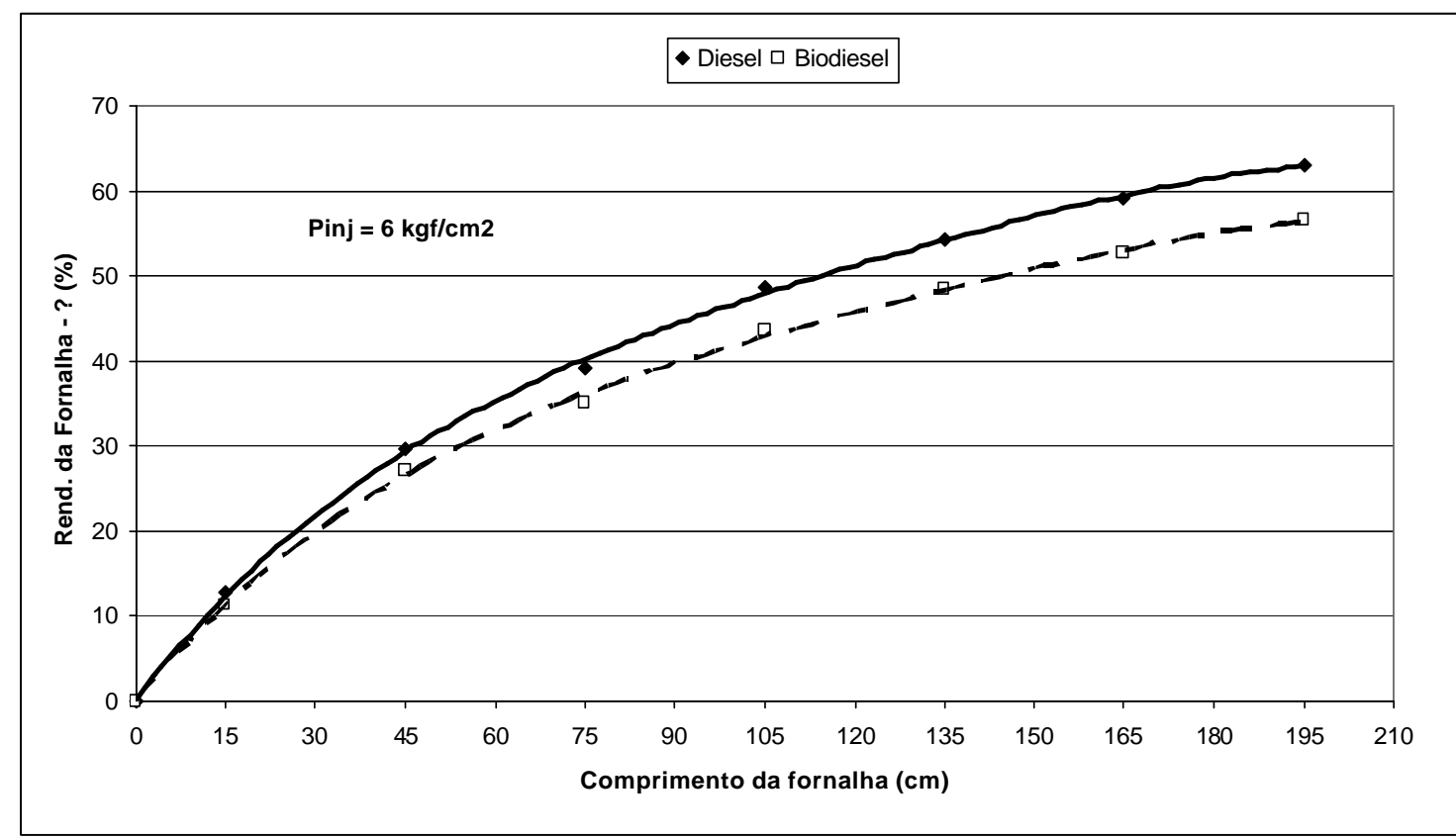

Gráfico 8 - Rendimento Térmico da Fornalha (Pinj - $\left.6 \mathrm{kgf} \mathrm{cm}^{-2}\right)$.

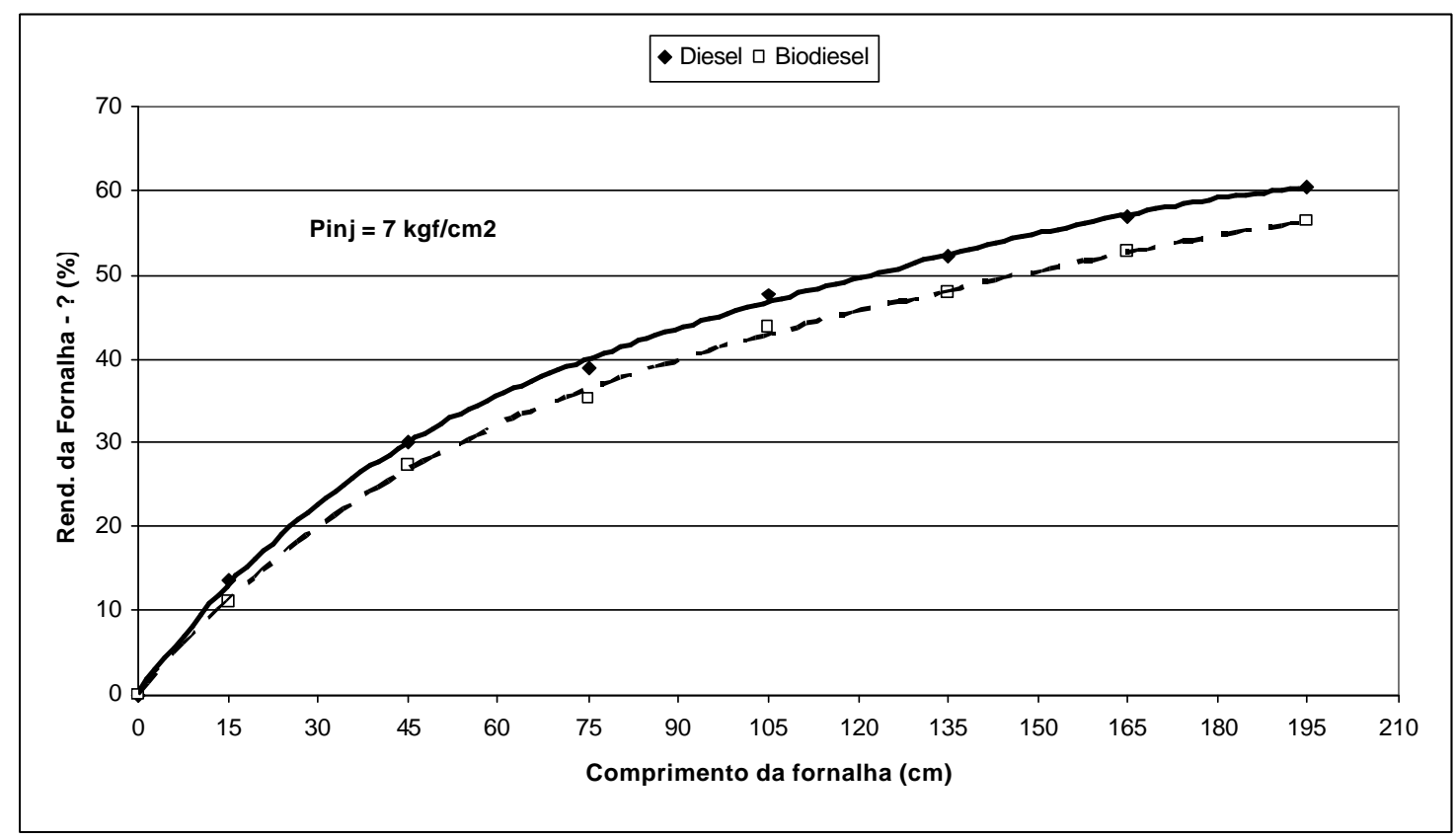

Gráfico 9 - Rendimento Térmico da Fornalha (Pinj - 7 kgf $\left.\mathbf{~ c m}^{-2}\right)$. 
Através da análise dos gráficos (8) e (9), nota-se que as curvas de tendência têm o mesmo comportamento, e na faixa estudada o diesel apresentou um pequeno aumento

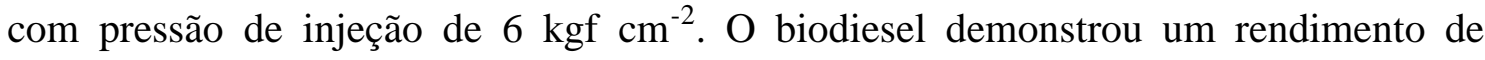
fornalha inferior ao diesel, isso pode ser explicado através da emissividade de cada combustível, sendo a chama do óleo diesel dotada de maior poder emissivo. Um outro fator que contribui para o melhor desempenho do diesel é a sua temperatura de chama mais elevada. Nas fotografias (10.a) e (10.b) observa-se que com uma mesma pressão de injeção $\left(7 \mathrm{kgf} \mathrm{cm}^{-2}\right)$, a chama do óleo diesel tem um formato mais espalhado e mais curto que a chama do biodiesel, proporcionando temperaturas mais elevadas nas regiões mais próximas do bico injetor.

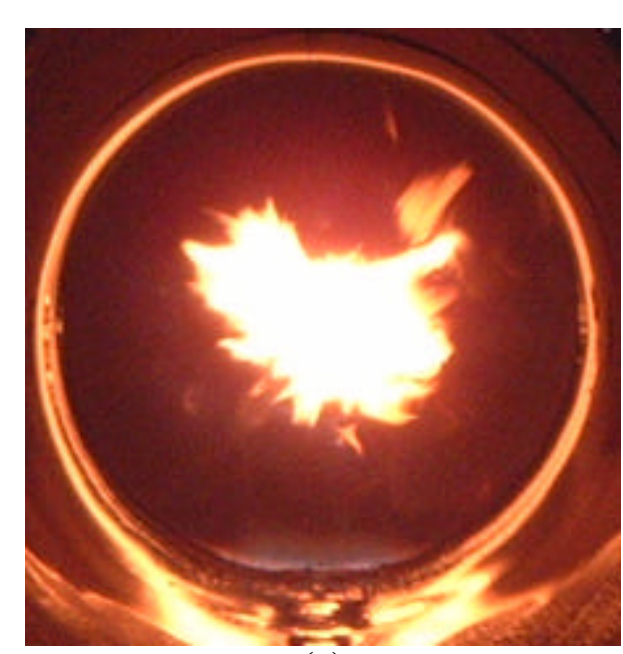

(a)

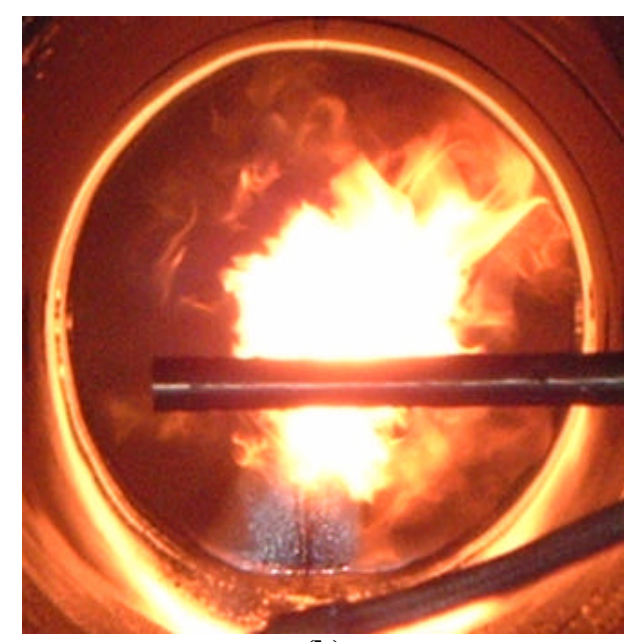

(b)

Fotografia 10 - (a) Chama do Biodiesel; (b) Chama do Diesel.

\section{4 - Temperatura de Chama}

Diferentes combustíveis possuem propriedades díspares de transferência de calor no momento da combustão. A respeito da transferência por radiação, a temperatura de chama é um fator predominante em relação a menor ou maior transferência. Nota-se, no gráfico (10), que a temperatura de chama do óleo diesel demonstrou-se maior em relação ao biodiesel, e isto é um fator importante para explicar a maior transferência de calor do óleo diesel observada nas regiões da câmara de combustão em que a chama estava presente. 


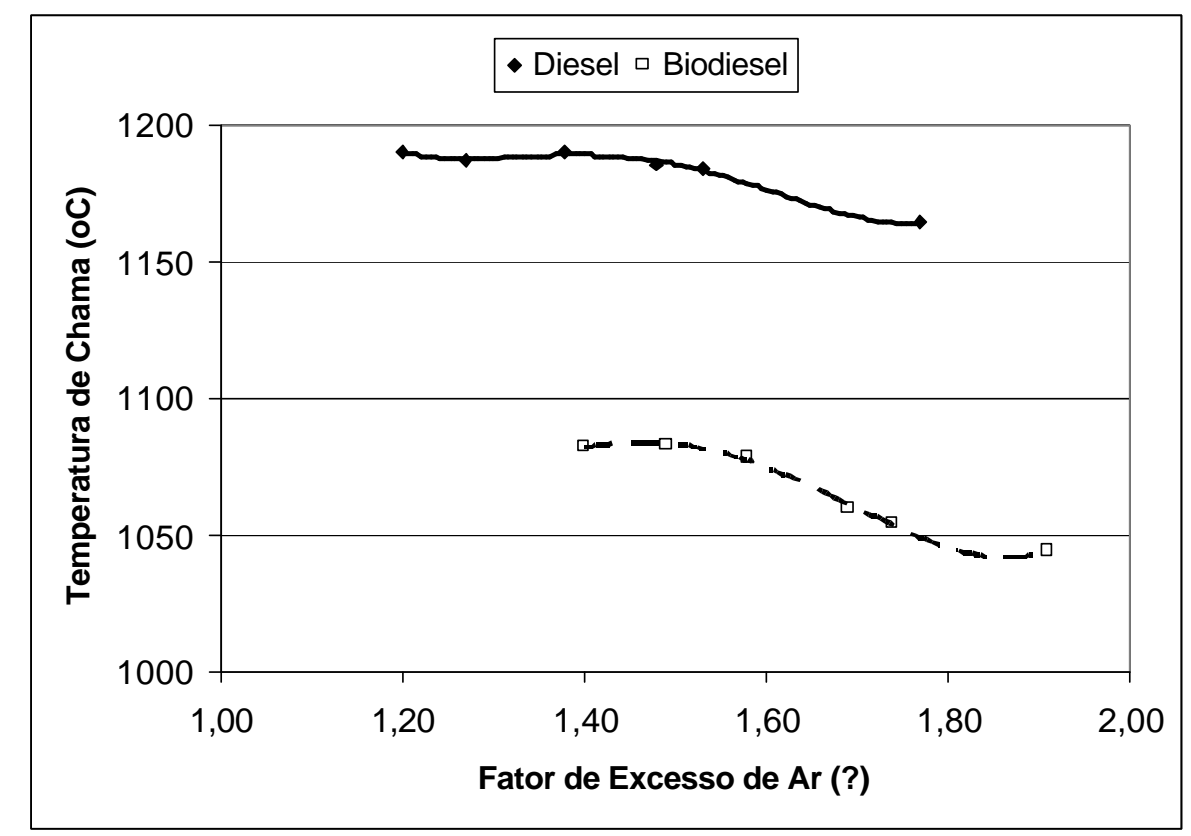

Gráfico 10 - Temperatura de Chama: Diesel e Biodiesel.

\section{5 - Perda de Carga}

Em função da vazão de combustível e da razão ar/combustível usada nos ensaios a taxa de fluxo de massa dos gases de exaustão foi inferior a $0,41 \mathrm{~kg} \mathrm{~m}^{-2} \mathrm{~s}^{-1}$ como mostra o gráfico (5). Logo, observa-se na figura (22), em anexo, que a perda de carga é próxima de zero. 


\section{6 - CONCLUSÕES}

Nos calorímetros de 12 a 8 observou-se que o óleo diesel proporcionou maior transferência de calor que o biodiesel. Nesses calorímetros a transferência de calor é predominantemente por radiação devido à chama estar presente nos calorímetros 12,11 e início do 10. Para a pressão de injeção de $7 \mathrm{kgf} \mathrm{cm}^{-2}$ o biodiesel apresentou maior transferência de calor nos calorímetros 7 e 6 . Isto aconteceu porque os gases de exaustão do biodiesel, que trocaram menos calor por radiação, chegaram a estes calorímetros com maior temperatura que os gases do óleo diesel, trocando assim mais calor por convecção.

Para a mesma pressão de injeção a taxa de fluxo mássico dos gases de exaustão do biodiesel é inferior a dos gases do diesel. Em função da menor taxa de fluxo mássico, a perda de carga dos gases de exaustão do biodiesel é inferior a do diesel, demandando assim menos potência do ventilador.

Apesar da menor transferência de calor por radiação na fornalha para o biodiesel, esse combustível pode substituir o óleo diesel em caldeiras flamotubulares, porém, é recomendável o monitoramento da temperatura na entrada da chaminé para, com base nesta informação, controlar a injeção de combustível a fim de garantir o mesmo rendimento total de caldeira (transferência de calor na fornalha e nos bancos de tubos).

A fornalha calorimétrica flamotubular desenvolvida configurou-se como um importante equipamento para a pesquisa do processo de combustão e da transferência de calor quando se pretende queimar combustíveis líquidos ou gasosos. Também pode ser utilizada para o desenvolvimento e ensaios de queimadores.

A combustão com a presença de chama na fornalha ocorre no máximo até uma distância do bico injetor correspondente a três vezes o diâmetro da fornalha. Portanto, dois módulos da fornalha calorimétrica são suficientes para o estudo na região de predominância da transferência de calor por radiação. Os outros dois módulos podem ser substituídos por bancos de tubos para o estudo do mecanismo de transferência de calor por convecção. A perda de carga na fornalha foi muito baixa, o que dificultou a regulagem da combustão pelo ar. Certamente com a introdução do banco de tubos esta perda aumentará.

Considerando que o comprimento da fornalha de caldeiras flamotubulares é no máximo igual a quatro vezes o seu diâmetro, conforme Gunn e Horton (1989), para uma 
fornalha de $30 \mathrm{~cm}$ de diâmetro como a deste trabalho, seu comprimento máximo seria de $120 \mathrm{~cm}$. Observando-se os gráficos 8 e 9 conclui-se que a troca de calor na fornalha de uma caldeira flamotubular usando óleo diesel corresponde à cerca de 50\% da energia injetada, enquanto que para o biodiesel corresponde à cerca de $45 \%$. O restante da energia deve ser trocado no banco de tubos de troca convectiva.

Verificou-se também que o queimador utilizado não apresentou problemas no momento em que os combustíveis foram substituídos, apesar de possuírem propriedades diferentes.

Constatou-se que as diferenças nas propriedades dos combustíveis têm reflexo direto na combustão dos mesmos, e influencia diretamente na temperatura de chama. A temperatura da chama do óleo diesel é cerca de $10 \%$ maior, transferindo quantidade superior de calor radiante para a água de arrefecimento.

Visualmente, verificou-se que a chama do óleo diesel, a uma mesma pressão de injeção, formou-se em uma região mais próxima do bico injetor e com um "leque" de angulação maior. Pode-se observar também, através de uma análise sensitiva que na queima do biodiesel os produtos de combustão apresentaram uma coloração menos escura, menos agressiva e com odor mais brando que o óleo diesel.

$\mathrm{Na}$ análise dos resultados obtidos, observou-se que no aspecto emissões ambos os combustíveis produziram baixos níveis percentuais de gases poluentes, e comparando-se os níveis de THC e $\mathrm{NO}_{\mathrm{x}}$ para ambos os combustíveis, pôde-se notar que o biodiesel demonstrou uma queda muito significante em relação ao óleo diesel.

Após a realização dos ensaios experimentais, a bancada ficou parada por aproximadamente 2 meses com o biodiesel em toda a linha de alimentação de combustível. No momento de se iniciar novos testes, observou-se que havia ocorrido a formação de um certo material "pegajoso" que impedia a passagem do combustível, principalmente no filtro. Uma alternativa para se solucionar este problema seria o préaquecimento do combustível, proporcionando assim, a limpeza da linha de alimentação. 


\section{7 - SUGESTÕES PARA TRABALHOS FUTUROS}

Substituir os módulos calorimétricos correspondentes aos calorímetros de 6 a 1 por módulos com bancos de tubos que permitam estudar o processo de transferência de calor por convecção nos tubos.

Estudar o uso de outros combustíveis alternativos e ou misturas deles, tais como álcool, d-limoneno, óleos vegetais “in natura”, etc.

Melhorar o sistema de controle da vazão de água em cada calorímetro instalando medidores individuais para cada célula.

Desenvolver e estudar queimadores específicos para os combustíveis alternativos. 


\section{8 - ANEXOS}

\section{Anexo I}

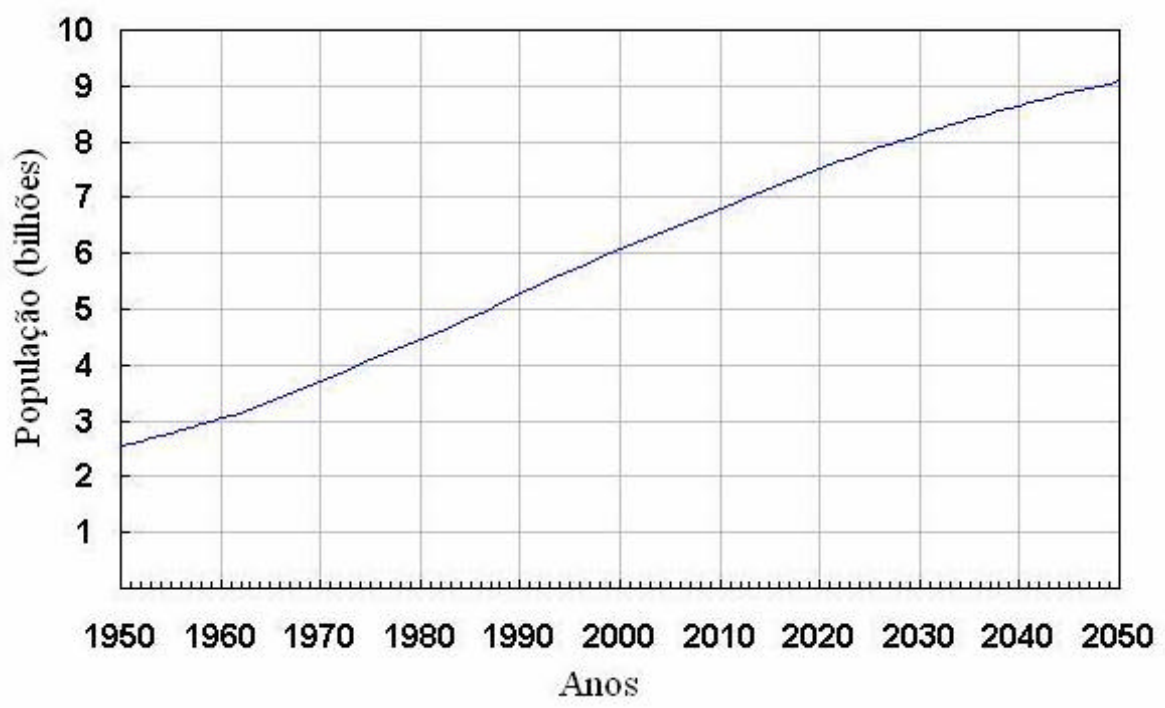

Figura 20 - População Mundial: 1950 - 2050

Fonte: U.S. Census Bureau, International Data Base 7-2003. 


\section{Anexo II \\ Especificações do Óleo Diesel

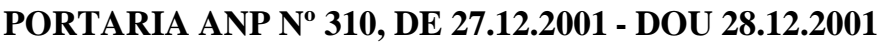 \\ REGULAMENTO TÉCNICO ANP No 6/2001}

\section{Normas aplicáveis}

A determinação das características dos produtos será realizada mediante o emprego de Normas Brasileiras (NBR) da Associação Brasileira de Normas Técnicas - ABNT ou de Normas da American Society for Testing and Materials - ASTM.

Os dados de precisão, repetitividade e reprodutibilidade fornecidos nos métodos relacionados a seguir, devem ser usados somente como guia para aceitação das determinações em duplicata do ensaio e não devem ser considerados como tolerância aplicada aos limites especificados neste Regulamento.

A análise do produto deverá ser realizada em amostra representativa do mesmo, obtida segundo método ASTM D 4057 - Practice for Manual Sampling of Petroleum and Petroleum Products.

As características incluídas na Tabela de Especificação anexa deverão ser determinadas de acordo com a publicação mais recente dos seguintes métodos de ensaio:

Tabela 6 - Aparência.

\begin{tabular}{lc}
\hline MÉTODO & \multicolumn{1}{c}{ TíTULO } \\
\hline ABNT & Produtos de Petróleo - Determinação da cor - Método do colorímetro ASTM \\
NBR14483 & ASTM Color of Petroleum Products \\
ASTM D 1500 & ASTM \\
\hline
\end{tabular}

Tabela 7 - Composição.

\begin{tabular}{lc}
\hline MÉTODO & \multicolumn{1}{c}{ TíTULO } \\
\hline ABNT & Produtos de Petróleo - Determinação da cor - Método do colorímetro ASTM \\
NBR14483 & \\
ASTM D 1500 & ASTM Color of Petroleum Products \\
\hline
\end{tabular}

Tabela 8 - Volatilidade (NR).

\begin{tabular}{ll}
\hline MÉTODO & \multicolumn{1}{c}{ TÍTULO } \\
\hline ABNT NBR 14533 & $\begin{array}{l}\text { Produtos de Petróleo - Determinação do enxofre por espectrometria de } \\
\text { fluorescência de Raios X (Energia Dispersiva) }\end{array}$ \\
ASTM D 1552 & $\begin{array}{l}\text { Sulfur in Petroleum Products (High-Temperature Method) } \\
\text { ASTM D 2622 }\end{array}$ \\
ASTM D 4294 & $\begin{array}{l}\text { Sulfur in Petroleum Products by X-Ray Spectrometry } \\
\text { Spectroscopy }\end{array}$ \\
ASTM D 5453 & $\begin{array}{l}\text { Total Sulfur in Light Hydrocarbons, Motor Fuels and Oils by Ultraviolet } \\
\text { Fluorescence }\end{array}$ \\
\hline
\end{tabular}


Tabela 9 - Fluidez.

\begin{tabular}{|c|c|}
\hline MÉTODO & TÍTULO \\
\hline ABNT NBR 7148 & $\begin{array}{l}\text { Petróleo e Produtos de Petróleo - Determinação da massa específica, } \\
\text { densidade relativa e API - Método do densímetro }\end{array}$ \\
\hline ABNT NBR 14598 & $\begin{array}{l}\text { Produtos de Petróleo - Determinação do Ponto de Fulgor pelo Vaso Fechado } \\
\text { Pensky Martens }\end{array}$ \\
\hline ABNT NBR 7974 & $\begin{array}{l}\text { Produtos de Petróleo - Determinação do ponto de fulgor pelo vaso fechado } \\
\text { TAG }\end{array}$ \\
\hline ABNT NBR 9619 & Produtos de Petróleo - Determinação da faixa de destilação \\
\hline ABNT NBR 14065 & $\begin{array}{l}\text { Destilados de Petróleo e Óleos Viscosos - Determinação da massa específica } \\
\text { e da densidade relativa pelo densímetro digital. }\end{array}$ \\
\hline ASTM D 56 & Flash Point by Tag Closed Tester \\
\hline ASTM D 86 & Distillation of Petroleum Products \\
\hline ASTM D 93 & Flash Point by Pensky-Martens Closed Cup Tester \\
\hline ASTM D 1298 & $\begin{array}{l}\text { Density, Relative Density (Specific Gravity) or API Gravity of Crude } \\
\text { Petroleum and Liquid Petroleum Products by Hydrometer Method }\end{array}$ \\
\hline ASTM D 3828 & Flash Point by Small Scale Closed Tester \\
\hline ASTM D 4052 & Density and Relative Density of Liquids by Digital Density Meter \\
\hline
\end{tabular}

Tabela 10 - Combustão.

\begin{tabular}{ll}
\hline MÉTODO & \multicolumn{1}{c}{ TÍTULO } \\
\hline ABNT NBR & $\begin{array}{l}\text { Produtos de petróleo - Líquidos transparentes e opacos - Determinação da } \\
\text { viscosidade cinemática e cálculo da viscosidade dinâmica }\end{array}$ \\
ABN41 & Óleo Diesel - Determinação do ponto de entupimento de filtro a frio \\
14747 & $\begin{array}{l}\text { Kinematic Viscosity of Transparent and Opaque Liquids (and the Calculation } \\
\text { of Dynamic Viscosity) }\end{array}$ \\
ASTM D 445 & Cold Filter Plugging Point of Diesel and Heating Fuels \\
\hline
\end{tabular}

Tabela 11 - Corrosão.

\begin{tabular}{ll}
\hline MÉTODO & \multicolumn{1}{c}{ TÍTULO } \\
\hline ABNT NBR 9842 & Produtos de Petróleo - Determinação do Teor de Cinzas \\
ABNT NBR & Produtos de Petróleo - Determinação do Resíduo de Carbono Ramsbottom \\
14318 & \\
ASTM D 482 & Ash from Petroleum Products \\
ASTM D 524 & Ramsbottom Carbon Residue of Petroleum Products \\
ASTM D 613 & Cetane Number Diesel \\
ASTM D 4737 & Calculated Cetane Index by Four Variable Equation \\
\hline
\end{tabular}


Tabela 12 - Contaminantes.

\begin{tabular}{ll}
\hline MÉTODO & \multicolumn{1}{c}{ TíTULO } \\
\hline ABNT NBR & $\begin{array}{l}\text { Produtos de Petróleo - Determinação da corrosividade - Método da lâmina de } \\
\text { cobre }\end{array}$ \\
ASTM9 & $\begin{array}{l}\text { Detection of Copper Corrosion from Petroleum Products by the Copper Strip } \\
\text { Tarnish Test }\end{array}$ \\
\hline
\end{tabular}

Tabela 13 - Especificação (NR).

\begin{tabular}{ll}
\hline MÉTODO & \multicolumn{1}{c}{ TíTULO } \\
\hline ABNT NBR & $\begin{array}{l}\text { Produtos de Petróleo - Determinação da Água e Sedimentos em Petróleo e } \\
14647\end{array}$ \\
OSTleos Combustíveis pelo Método de Centrifugação. \\
$\begin{array}{l}\text { Test Method for Water and Sediment in Fuel Oils by the Centrifuge Method } \\
\text { (Laboratory Procedure) }\end{array}$ \\
\hline
\end{tabular}

Nota:

(1) O Óleo Diesel Metropolitano (D) deverá ser obrigatoriamente comercializado nos municípios relacionados, conforme determinação do Ministério do Meio Ambiente.

(2) A visualização será realizada em proveta de vidro, conforme a utilizada no Método NBR 7148 ou ASTM D 1298.

(3) Limite requerido antes da adição do corante. O corante vermelho, segundo especificação constante da Tabela (14) deste Regulamento Técnico, deverá ser adicionado no teor de 20mg/l pelas Refinarias, Centrais de Matérias-Primas Petroquímicas, Importadores e Formuladores.

(4) As Refinarias, Centrais de Matérias-Primas Petroquímicas, Importadores e Formuladores de óleo diesel automotivo deverão atender às exigências referentes à adição do corante a partir de 01/01/2003.(NR)

(5) Limites conforme Tabela (14).

(6) Alternativamente ao ensaio de Número de Cetano fica permitida a determinação do Índice de Cetano calculado pelo método ASTM D 4737, com valor mínimo de 45. Em caso de desacordo de resultados prevalecerá o valor do Número de Cetano.

Nota:

A Portaria ANP n ${ }^{\circ}$ 54, de 26.4.2002 - DOU 29.4.2002 - Efeitos a partir de 29.4.2002, alterou para o dia $1^{\circ}$.9.2002 a data para o atendimento da exigência referente à adição do corante vermelho ao Óleo Diesel Interior. 
Tabela 14 - Ponto de Entupimento de Filtro a Frio.

\begin{tabular}{|c|c|c|c|c|c|}
\hline \multirow{3}{*}{ CARACTERÍSTICAS } & \multirow{3}{*}{ UNIDADES } & \multicolumn{2}{|c|}{ LIMITES } & \multicolumn{2}{|c|}{ MÉTODOS } \\
\hline & & \multicolumn{2}{|r|}{ TIPOS } & \multirow[b]{2}{*}{ ABNT } & \multirow[b]{2}{*}{ ASTM } \\
\hline & & $\begin{array}{l}\text { Interior } \\
\text { (B) }\end{array}$ & $\begin{array}{l}\text { Metropolitano } \\
\text { (D) (1) }\end{array}$ & & \\
\hline \multicolumn{6}{|l|}{ APARÊNCIA } \\
\hline Aspecto & & \multicolumn{2}{|c|}{$\begin{array}{l}\text { Límpido isento de } \\
\text { impurezas }\end{array}$} & \multicolumn{2}{|l|}{ Visual (2) } \\
\hline Cor ASTM, máx. & & $\begin{array}{c}3,0 \\
(3)(4)\end{array}$ & 3,0 & $\begin{array}{l}\text { NBR } \\
14483\end{array}$ & D 1500 \\
\hline \multicolumn{6}{|l|}{ COMPOSIÇÃO } \\
\hline \multirow[t]{3}{*}{ Enxofre total, máx. } & \multirow[t]{3}{*}{$\%$ massa } & \multirow[t]{3}{*}{0,35} & \multirow[t]{3}{*}{0,20} & - & D 1552 , \\
\hline & & & & - & D 2622, \\
\hline & & & & NBR14533 & D 4294 \\
\hline \multicolumn{6}{|l|}{ VOLATILIDADE } \\
\hline Destilação & ${ }^{\circ} \mathrm{C}$ & & & NBR 9619 & D 86 \\
\hline $\begin{array}{l}50 \% \text { vol., recuperado, } \\
\text { máx. }\end{array}$ & \multicolumn{3}{|c|}{$245,0-310,0$} & & \\
\hline $\begin{array}{l}85 \% \text { vol., recuperado, } \\
\text { máx. }\end{array}$ & & 370,0 & 360,0 & & \\
\hline \multirow{2}{*}{$\begin{array}{l}\text { Massa específica a } \\
20^{\circ} \mathrm{C}\end{array}$} & \multirow[t]{2}{*}{$\mathrm{kg} / \mathrm{m} 3$} & \multirow{2}{*}{\multicolumn{2}{|c|}{$\begin{array}{c}820 \mathrm{a} \\
880\end{array}$}} & NBR 7148, & D 1298, \\
\hline & & & & $\begin{array}{c}\text { NBR } \\
14065\end{array}$ & D 4052 \\
\hline \multirow[t]{2}{*}{ Ponto de fulgor, mín. } & \multirow[t]{2}{*}{${ }^{\circ} \mathrm{C}$} & \multirow{2}{*}{\multicolumn{2}{|c|}{38,0}} & NBR 7974 & $\begin{array}{c}\text { D 56,D } \\
93\end{array}$ \\
\hline & & & & $\begin{array}{l}\text { NBR } \\
14598\end{array}$ & D 3828 \\
\hline \multicolumn{6}{|l|}{ FLUIDEZ } \\
\hline Viscosidade a $40^{\circ} \mathrm{C}$ & $(\mathrm{mm} 2 / \mathrm{s}) \mathrm{cSt}$ & &, 5 a 5,5 & $\begin{array}{c}\text { NBR } \\
10441\end{array}$ & D 445 \\
\hline $\begin{array}{l}\text { Ponto de entupimento } \\
\text { de filtro . a frio }\end{array}$ & ${ }^{\circ} \mathrm{C}$ & & (5) & $\begin{array}{l}\text { NBR } \\
14747\end{array}$ & D 6371 \\
\hline \multicolumn{6}{|l|}{ COMBUSTÃO } \\
\hline $\begin{array}{l}\text { Número de Cetano, } \\
\text { mín. (6) }\end{array}$ & - & & 42 & - & D 613 \\
\hline $\begin{array}{l}\text { Resíduo de Carbono } \\
\text { Ramsbottom no resíduo } \\
\text { dos } 10 \% \text { finais da } \\
\text { Destilação, máx. }\end{array}$ & $\%$ massa & & 0,25 & NBR14318 & D 524 \\
\hline Cinzas, máx. & $\%$ massa & & 0,020 & NBR 9842 & D 482 \\
\hline \multicolumn{6}{|l|}{ CORROSÃO } \\
\hline $\begin{array}{l}\text { Corrosividade ao } \\
\text { cobre, } 3 \text { h a } 50^{\circ} \mathrm{C}, \text { máx }\end{array}$ & - & & 1 & $\begin{array}{l}\text { NBR } \\
14359\end{array}$ & D 130 \\
\hline
\end{tabular}




\begin{tabular}{|c|c|c|c|c|}
\hline \multicolumn{5}{|l|}{ CONTAMINANTES } \\
\hline $\begin{array}{l}\text { Água e Sedimentos, } \\
\text { máx. }\end{array}$ & $\%$ volume & 0,05 & $\begin{array}{c}\text { NBR } \\
14647\end{array}$ & D 1796 \\
\hline
\end{tabular}

Tabela 15 - Especificação do Corante para o Óleo Diesel Interior.

\begin{tabular}{lcccccc}
\hline \multirow{2}{*}{$\begin{array}{c}\text { UNIDADES } \\
\text { FEDERAÇÃO }\end{array}$} & JAN & FEV & MAR & ABR & MAI & JUN \\
\cline { 2 - 7 } LEMITES MÁXIMOS ${ }^{\circ} \mathbf{C}$ \\
\hline SP - MG - MS & 12 & 12 & 12 & 7 & 3 & 3 \\
GO/DF - MT - & 12 & 12 & 12 & 10 & 5 & 5 \\
ES - RJ & 10 & 10 & 7 & 7 & 0 & 0 \\
PR - SC - RS & JUL & AGO & SET & OUT & NOV & DEZ \\
\hline & 3 & 3 & 7 & 9 & 9 & 12 \\
\hline SP - MG - MS & 5 & 8 & 8 & 10 & 12 & 12 \\
GO/DF - MT - & 0 & 0 & 0 & 7 & 7 & 10 \\
ES - RJ & & & & & & \\
PR - SC - RS & 0 &
\end{tabular}

Nota:

(*) A Absorbância deve ser determinada em uma solução volumétrica de $20 \mathrm{mg} / 1$ do corante em tolueno P.A., medida em célula de caminho ótico de $1 \mathrm{~cm}$, na faixa especificada para o comprimento de onda. 


\section{Anexo III}

Tabela 16 - Especificação preliminar do Biodiesel.

\begin{tabular}{|c|c|c|c|c|c|}
\hline \multirow[t]{2}{*}{ CARACTERISTICAS } & \multirow[t]{2}{*}{ UNIDADES } & \multirow[t]{2}{*}{ LIMITES } & \multicolumn{3}{|c|}{ METODOS } \\
\hline & & & $\begin{array}{l}\text { ABNT } \\
\text { NBR }\end{array}$ & $\begin{array}{l}\text { ASTM } \\
\text { D }\end{array}$ & ISSO \\
\hline Ponto de fulgor, mín. & ${ }^{\circ} \mathrm{C}$ & 100,0 & $\begin{array}{c}14598 \\
-\end{array}$ & $\begin{array}{c}93 \\
-\end{array}$ & $\begin{array}{c}- \\
\text { ISO/CD } 3679\end{array}$ \\
\hline Água e sedimentos, máx. & $\%$ volume & 0,050 & - & 2709 & - \\
\hline Viscosidade a $40^{\circ} \mathrm{C}$. & $\mathrm{mm} 2 / \mathrm{s}$ & Anotar (1) & 10441 & 445 & EN ISO 3104 \\
\hline Cinzas sulfatadas, máx. & $\%$ massa & 0,020 & 9842 & 874 & ISO 3987 \\
\hline Enxofre total, máx. & $\%$ massa & 0,001 & - & $\begin{array}{c}5453 \\
-\end{array}$ & EN ISO 14596 \\
\hline $\begin{array}{l}\text { Corrosividade ao cobre, } \\
3 \text { h a } 50^{\circ} \mathrm{C} \text {, máx. }\end{array}$ & - & 1 & 14359 & 130 & EN ISO 2160 \\
\hline Número de Cetano, mín. & - & 45 & - & 613 & EN ISO 5165 \\
\hline $\begin{array}{l}\text { Ponto de entupimento de } \\
\text { filtro a frio, máx. }\end{array}$ & ${ }^{\circ} \mathrm{C}$ & (2) & 14747 & 6371 & - \\
\hline $\begin{array}{l}\text { Resíduo de carbono, } \\
\text { máx. }\end{array}$ & $\%$ massa & 0,05 & - & $\begin{array}{c}4530 \\
189\end{array}$ & $\begin{array}{c}\text { EN ISO } 10370 \\
-\end{array}$ \\
\hline Índice de acidez, máx. & $\mathrm{mg} \mathrm{KOH} / \mathrm{g}$ & 0,80 & $\begin{array}{c}14448 \\
-\end{array}$ & $\begin{array}{c}664 \\
-\end{array}$ & pr EN 14104 \\
\hline Glicerina livre, máx. & $\%$ massa & 0,02 & $\begin{array}{l}- \\
-\end{array}$ & $\begin{array}{c}6584 \\
- \\
-\end{array}$ & $\begin{array}{l}- \\
\text { pr EN } 14105 \\
\text { pr EN } 14106\end{array}$ \\
\hline Glicerina total, máx. & $\%$ massa & 0,38 & - & $\begin{array}{c}6584 \\
-\end{array}$ & pr EN 14105 \\
\hline $\begin{array}{l}\text { Aspecto } \\
\text { Destilação; 95\% vol. } \\
\text { Recuperado, máx. }\end{array}$ & ${ }^{-} \mathrm{C}$ & $\begin{array}{l}\text { LII (3) } \\
360(4)\end{array}$ & - & 1160 & - \\
\hline Massa específica a $20^{\circ} \mathrm{C}$ & $\mathrm{kg} / \mathrm{m} 3$ & $\begin{array}{l}\text { Anotar } \\
(5)\end{array}$ & $\begin{array}{l}7148 \\
14065\end{array}$ & $\begin{array}{l}1298 \\
4052\end{array}$ & $\begin{array}{l}- \\
-\end{array}$ \\
\hline $\begin{array}{l}\text { Metanol ou Etanol, máx. } \\
\text { Índice de iodo, máx. }\end{array}$ & $\begin{array}{l}\% \text { massa } \\
\% \text { massa }\end{array}$ & $\begin{array}{c}0,5 \\
\text { Anotar }\end{array}$ & - & - & $\begin{array}{l}\text { pr EN } 14110 \\
\text { pr EN } 14111\end{array}$ \\
\hline Monoglicerídeos, máx. & $\%$ massa & 1,00 & - & $\begin{array}{c}6584 \\
-\end{array}$ & $\stackrel{-}{\text { pr EN } 14105}$ \\
\hline Diglicerídeos, máx. & $\%$ massa & 0,25 & - & $\begin{array}{c}6584 \\
-\end{array}$ & pr EN 14105 \\
\hline Triglicerídeos, máx. & $\%$ massa & 0,25 & - & $\begin{array}{c}6584 \\
-\end{array}$ & pr EN 14105 \\
\hline Sódio + Potássio, máx & $\mathrm{mg} / \mathrm{kg}$ & 10 & - & - & $\begin{array}{l}\text { pr EN } 14108 \\
\text { pr EN } 14109\end{array}$ \\
\hline $\begin{array}{l}\text { Fósforo, máx. } \\
\text { Estabilidade à oxidação a } \\
110^{\circ} \mathrm{C}, \text { mín }\end{array}$ & $\underset{\mathrm{H}}{\mathrm{mg} / \mathrm{kg}}$ & $\begin{array}{c}10 \\
6\end{array}$ & - & $\begin{array}{c}4951 \\
-\end{array}$ & $\begin{array}{l}\text { pr EN } 14107 \\
\text { pr EN } 14112\end{array}$ \\
\hline
\end{tabular}

Fonte: Agência Nacional do Petróleo - Regulamento Técnico ANP N² 2/2003.

Nota:

(1) A mistura biodiesel - óleo diesel utilizada deverá obedecer aos limites estabelecidos para Viscosidade a $40{ }^{\circ} \mathrm{C}$ constantes da Portaria ANP que especifica óleo diesel automotivo, em vigor.

(2) A mistura biodiesel -óleo diesel utilizada deverá obedecer aos limites estabelecidos para Ponto de entupimento de filtro a frio constantes da Portaria ANP que especifica óleo diesel automotivo, em vigor

(3) LII - Límpido e isento de impurezas

(4) Temperatura equivalente na pressão atmosférica. 
(5) A mistura biodiesel - óleo diesel utilizada deverá obedecer aos limites estabelecidos para Massa específica a $20^{\circ} \mathrm{C}$ constantes da portaria ANP que especifica óleo diesel automotivo, em vigor. 


\section{Anexo IV}

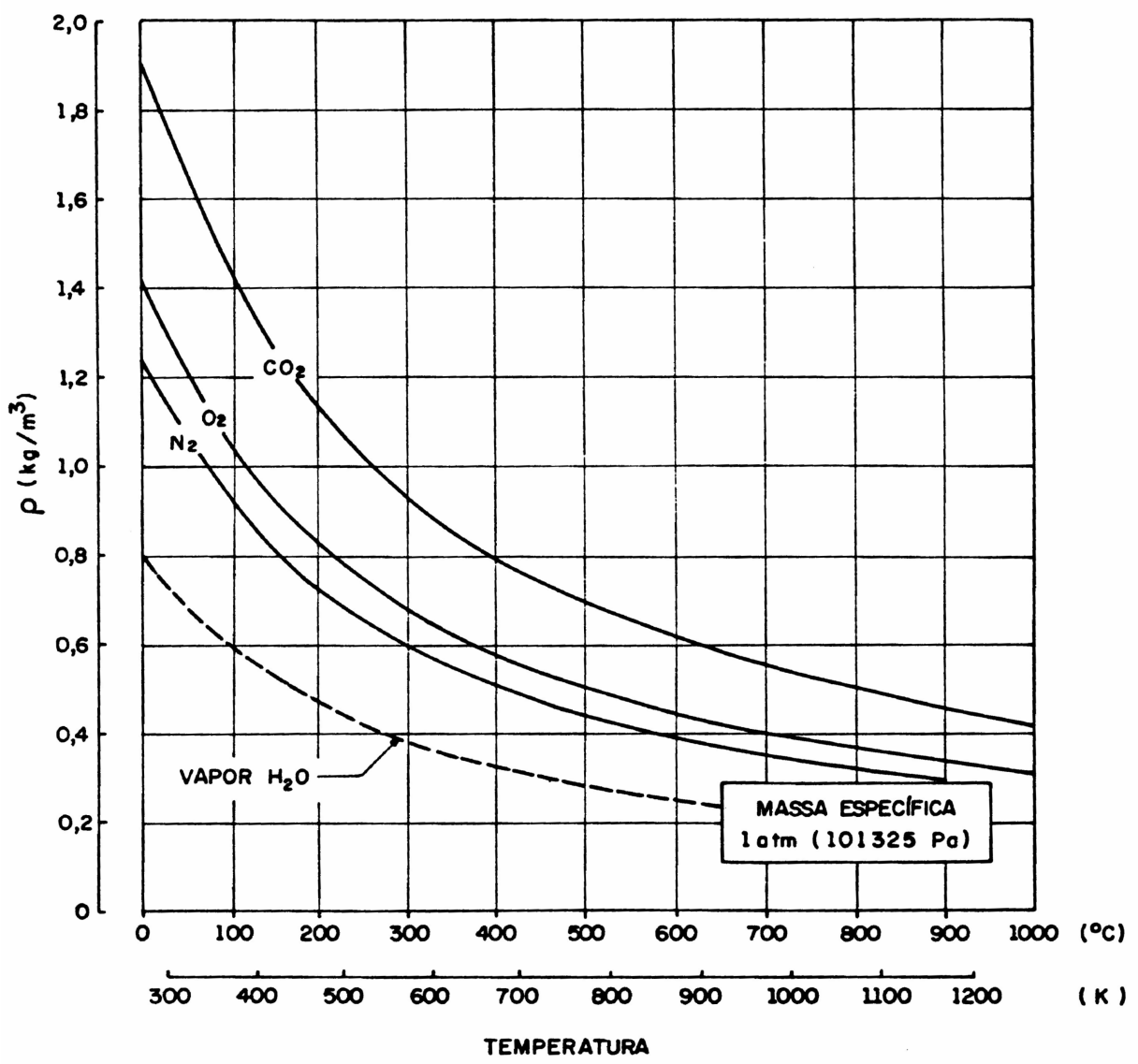

Figura 21 - Massa específica dos gases da combustão.

Fonte: Bazzo (1992). 


\section{Anexo V}

Tabela 17 - Calibração do rotâmetro para medição da vazão de água.

\begin{tabular}{|c|c|c|c|c|c|}
\hline $\begin{array}{c}V a z \tilde{a} o \\
(l / s)\end{array}$ & $\begin{array}{l}\operatorname{Vaz} \tilde{a} o \\
\left(m^{3} / h\right)\end{array}$ & $\begin{array}{c}\% \text { no } \\
\text { rotâmetro }\end{array}$ & $\begin{array}{c}\text { Vazãa } \\
\text { Calculada }(l / s)\end{array}$ & $\begin{array}{c}\text { Vazãa } \\
\text { Calculada } \\
\left(m^{3} / h\right)\end{array}$ & erro \% \\
\hline 0,0205 & 0,0738 & 10 & 0,02020 & 0,07271 & 1,481317073 \\
\hline 0,0362 & 0,13032 & 20 & 0,03652 & 0,13147 & 0,882127072 \\
\hline 0,0533 & 0,19188 & 30 & 0,05284 & 0,19023 & 0,858667917 \\
\hline 0,068 & 0,2448 & 40 & 0,06917 & 0,24900 & 1,713720588 \\
\hline 0,0864 & 0,31104 & 50 & 0,08549 & 0,30776 & 1,055173611 \\
\hline 0,1005 & 0,3618 & 60 & 0,10181 & 0,36652 & 1,30480597 \\
\hline 0,1192 & 0,42912 & 70 & 0,11813 & 0,42528 & 0,894018456 \\
\hline 0,1347 & 0,48492 & 80 & 0,13446 & 0,48405 & 0,180155902 \\
\hline 0,1514 & 0,54504 & 90 & 0,15078 & 0,54281 & 0,409293263 \\
\hline 0,1663 & 0,59868 & 100 & 0,16710 & 0,60157 & 0,483060734 \\
\hline
\end{tabular}

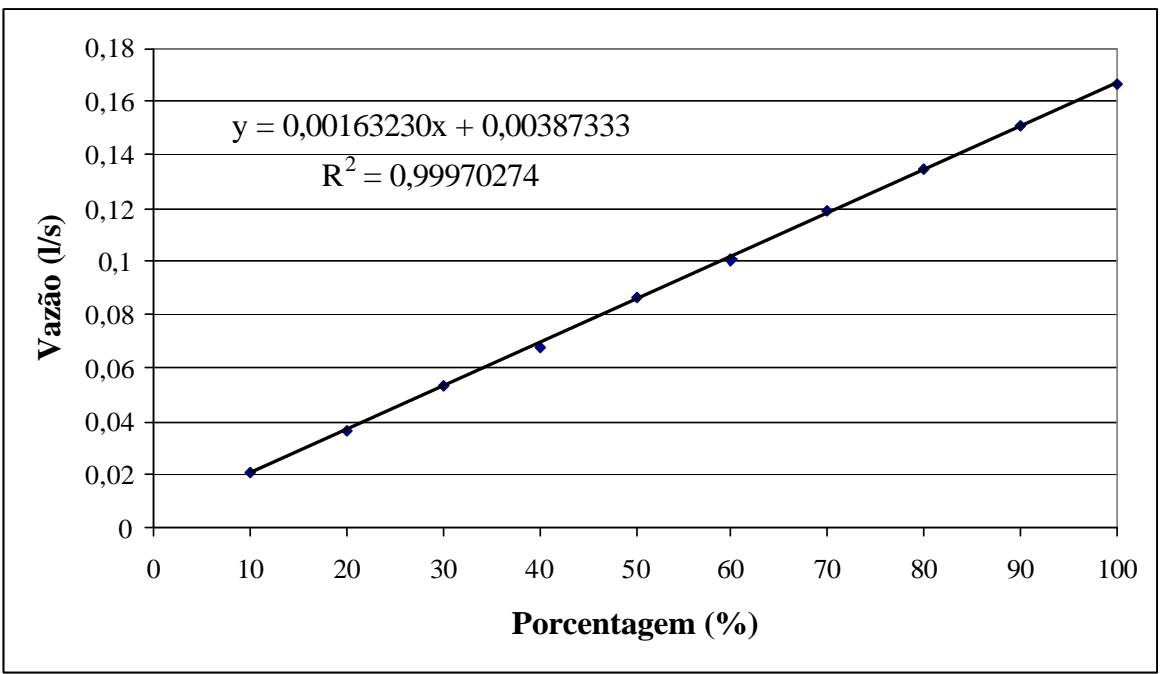

Gráfico 11 - Reta e polinômio de ajuste da calibração do rotâmetro de vazão da água. 


\section{Anexo VI}

Tabela 18 - Propriedades de Combustíveis Diesel e Biodiesel.

\begin{tabular}{lccc}
\hline Propriedades & Óleo Diesel & Biodiesel & Procedimento \\
\hline Peso específico @ $15 / 15^{\circ} \mathrm{C}$ & 0,8380 & 0,8830 & ASTM D1298 \\
Cor & 1,0 & 6,0 & ASTM D1500 \\
Ponto de névoa $\left({ }^{\circ} \mathrm{C}\right)$ & $\mathrm{NA}^{\mathrm{a}}$ & 0,0 & ASTM D2500 \\
Ponto de fluidez $\left({ }^{\circ} \mathrm{C}\right)$ & $-3,0$ & 0,0 & ASTM D97 \\
Ponto de fulgor $\left({ }^{\circ} \mathrm{C}\right)$ & 75,0 & 109 & ASTM D93 \\
Índice de refração & $\mathrm{NA}$ & 1,45 & - \\
Poder calorífico superior $(\mathrm{kJ} / \mathrm{kg})$ & 43730 & 39305 & ASTM D240 \\
Viscosidade cinemática @ $20^{\circ} \mathrm{C}(\mathrm{cSt})$ & $\mathrm{NA}$ & 15,09 & ASTM D445 \\
\hline
\end{tabular}

${ }^{a} \mathrm{NA}$ - não avaliado de acordo com as normas.

Fonte: Tashtoush et al. (2003). 


\section{Anexo VII}

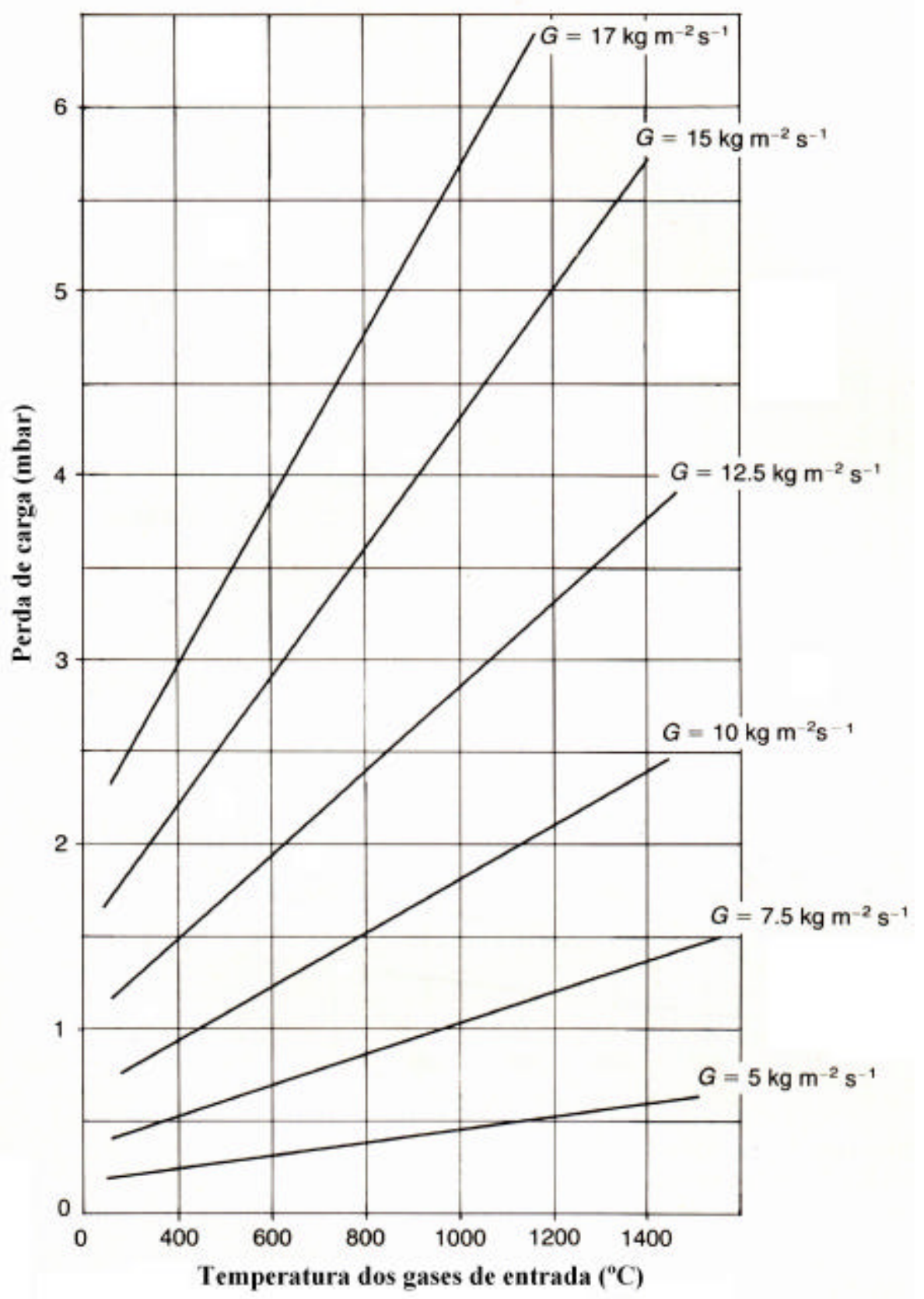

Figura 22 - Perda de carga na entrada dos tubos.

Fonte: Gunn e Horton (1989). 


\section{Anexo VIII}

Tabela 19 - Planilha de dados dos ensaios a 6 e 7 kgf cm-2 na combustão de óleo diesel.

\begin{tabular}{|c|c|c|c|c|c|c|}
\hline $\begin{array}{l}\text { Pinj = } 6 \\
\mathrm{kgf} / \mathrm{cm} 2\end{array}$ & $\begin{array}{c}\text { Consumo de } \\
\text { Combustível }(\mathrm{I} / \mathrm{h})=\end{array}$ & 5,112 & $54,537 \mathrm{~kJ} / \mathrm{s}$ & & & \\
\hline Calorímetro & $\begin{array}{c}\text { Distância em relação ao } \\
\text { queimador }(\mathrm{cm})\end{array}$ & $\begin{array}{l}\text { Temperatura de } \\
\text { entrada }\left({ }^{\circ} \mathrm{C}\right)\end{array}$ & $\begin{array}{l}\text { Temperatura de } \\
\text { saída }\left({ }^{\circ} \mathrm{C}\right)\end{array}$ & $\begin{array}{c}\text { Vazão de Água } \\
(\mathrm{kg} / \mathrm{s})\end{array}$ & $\begin{array}{c}\% \text { no } \\
\text { rotâmetro }\end{array}$ & $\begin{array}{c}\text { Q água } \\
(\mathrm{kJ} / \mathrm{s})\end{array}$ \\
\hline Bico & 0 & 25,2 & 25,2 & 0,1556 & 90,0 & 0 \\
\hline 12 & 15 & 26,8 & 37,4 & 0,1556 & 90,0 & 6,9009 \\
\hline 11 & 45 & 27,1 & 41,1 & 0,1565 & 90,5 & 9,1642 \\
\hline 10 & 75 & 27,3 & 35,3 & 0,1565 & 90,5 & 5,2367 \\
\hline 9 & 105 & 27,6 & 35,6 & 0,1539 & 89,0 & 5,1513 \\
\hline 8 & 135 & 27,6 & 32,2 & 0,1565 & 90,5 & 3,0111 \\
\hline 7 & 165 & 27,9 & 31,9 & 0,1565 & 90,5 & 2,6183 \\
\hline 6 & 195 & 27,8 & 31,1 & 0,1548 & 89,5 & 2,1367 \\
\hline
\end{tabular}

\begin{tabular}{|c|c|c|c|c|c|c|}
\hline $\begin{array}{r}\text { Pinj = } 7 \\
\mathrm{kgf} / \mathrm{cm} 2\end{array}$ & $\begin{array}{c}\text { Consumo de } \\
\text { Combustível }(\mathrm{l} / \mathrm{h})=\end{array}$ & 6,014 & $64,160 \mathrm{~kJ} / \mathrm{s}$ & & & \\
\hline Calorímetro & $\begin{array}{c}\text { Distância em relação ao } \\
\text { queimador }(\mathrm{cm})\end{array}$ & $\begin{array}{l}\text { Temperatura de } \\
\text { entrada }\left({ }^{\circ} \mathrm{C}\right)\end{array}$ & $\begin{array}{l}\text { Temperatura de } \\
\text { saída }\left({ }^{\circ} \mathrm{C}\right)\end{array}$ & $\begin{array}{c}\text { Vazão de Água } \\
\text { (kg/s) }\end{array}$ & $\begin{array}{c}\text { \% no } \\
\text { rotâmetro }\end{array}$ & $\begin{array}{c}\text { Q água } \\
(\mathrm{kJ} / \mathrm{s})\end{array}$ \\
\hline Bico & 0 & 25,2 & 25,2 & 0,1556 & 90,0 & 0 \\
\hline 12 & 15 & 28,1 & 40,8 & 0,1548 & 89,5 & 8,2229 \\
\hline 11 & 45 & 28,2 & 43,6 & 0,1573 & 91,0 & 10,1354 \\
\hline 10 & 75 & 28,4 & 36,6 & 0,1539 & 89,0 & 5,2801 \\
\hline 9 & 105 & 29,1 & 37,3 & 0,1565 & 90,5 & 5,3676 \\
\hline 8 & 135 & 28,9 & 33,2 & 0,1548 & 89,5 & 2,7841 \\
\hline 7 & 165 & 28,9 & 33,1 & 0,1573 & 91,0 & 2,7642 \\
\hline 6 & 195 & 29 & 32,3 & 0,1556 & 90,0 & 2,1484 \\
\hline
\end{tabular}




\section{Anexo IX}

Tabela 20 - Planilha de dados dos ensaios a 6 e 7 kgf $\mathrm{cm}^{-2}$ na combustão de biodiesel.

\begin{tabular}{|c|c|c|c|c|c|c|}
\hline $\begin{array}{r}\text { Pinj = } 6 \\
\mathrm{kgf} / \mathrm{cm} 2\end{array}$ & $\begin{array}{c}\text { Consumo de } \\
\text { Combustível }(\mathrm{l} / \mathrm{h})=\end{array}$ & 5,497 & $52,757 \mathrm{~kJ} / \mathrm{s}$ & & & \\
\hline Calorímetro & $\begin{array}{c}\text { Distância em relação ao } \\
\text { queimador }(\mathrm{cm})\end{array}$ & $\begin{array}{l}\text { Temperatura de } \\
\text { entrada }\left({ }^{\circ} \mathrm{C}\right)\end{array}$ & $\begin{array}{l}\text { Temperatura de } \\
\text { saída }\left({ }^{\circ} \mathrm{C}\right)\end{array}$ & $\begin{array}{c}\text { Vazão de Água } \\
(\mathrm{kg} / \mathrm{s})\end{array}$ & $\begin{array}{c}\text { \% no } \\
\text { rotâmetro }\end{array}$ & $\begin{array}{c}\text { Q água } \\
(\mathrm{kJ} / \mathrm{s})\end{array}$ \\
\hline Bico & 0 & 25,2 & 25,2 & 0,1556 & 90,0 & 0 \\
\hline 12 & 15 & 25,7 & 34,7 & 0,1565 & 90,5 & 5,8913 \\
\hline 11 & 45 & 25,8 & 38,8 & 0,1548 & 89,5 & 8,4172 \\
\hline 10 & 75 & 25,9 & 32,5 & 0,1539 & 89,0 & 4,2499 \\
\hline 9 & 105 & 26,6 & 33,4 & 0,1548 & 89,5 & 4,4028 \\
\hline 8 & 135 & 26,1 & 30,1 & 0,1556 & 90,0 & 2,6041 \\
\hline 7 & 165 & 25,9 & 29,5 & 0,1548 & 89,5 & 2,3309 \\
\hline 6 & 195 & 25,9 & 28,9 & 0,1548 & 89,5 & 1,9424 \\
\hline
\end{tabular}

\begin{tabular}{|c|c|c|c|c|c|c|}
\hline $\begin{array}{r}\text { Pinj = } 7 \\
\mathrm{kgf} / \mathrm{cm} 2\end{array}$ & $\begin{array}{c}\text { Consumo de } \\
\text { Combustível }(\mathrm{I} / \mathrm{h})=\end{array}$ & 5,809 & $55,751 \mathrm{~kJ} / \mathrm{s}$ & & & \\
\hline Calorímetro & $\begin{array}{c}\text { Distância em relação ao } \\
\text { queimador (cm) }\end{array}$ & $\begin{array}{l}\text { Temperatura de } \\
\text { entrada }\left({ }^{\circ} \mathrm{C}\right)\end{array}$ & $\begin{array}{l}\text { Temperatura de } \\
\text { saída }\left({ }^{\circ} \mathrm{C}\right)\end{array}$ & $\begin{array}{c}\text { Vazão de Água } \\
(\mathrm{kg} / \mathrm{s})\end{array}$ & $\begin{array}{c}\text { \% no } \\
\text { rotâmetro }\end{array}$ & $\begin{array}{c}\text { Q água } \\
(\mathrm{kJ} / \mathrm{s})\end{array}$ \\
\hline Bico & 0 & 25,2 & 25,2 & 0,1556 & 90,0 & 0 \\
\hline 12 & 15 & 26,0 & 35,4 & 0,1565 & 90,5 & 6,1531 \\
\hline 11 & 45 & 26,1 & 39,9 & 0,1565 & 90,5 & 9,0333 \\
\hline 10 & 75 & 26,2 & 33,0 & 0,1556 & 90,0 & 4,4270 \\
\hline 9 & 105 & 27,1 & 34,4 & 0,1556 & 90,0 & 4,7525 \\
\hline 8 & 135 & 26,6 & 30,0 & 0,1548 & 89,5 & 2,2014 \\
\hline 7 & 165 & 28,0 & 32,1 & 0,1565 & 90,5 & 2,6838 \\
\hline 6 & 195 & 28,1 & 31,3 & 0,1539 & 89,0 & 2,0605 \\
\hline
\end{tabular}




\section{9 - REFERÊECIAS}

ANNARATONE, D. (1968). Sul calore irraggiato in câmera di combustione. Il Calore, n. 11, p.559-568.

ANNARATONE, D. (1983). Sul flusso di picco nelle caldaie a tubi da fumo. La Termotecnica, Milan, n.4, p.79-86, apr.

ASME VIII - The American Society of Mechanical Engineers (section I - Power Boilers).

BAZZO, E. (1992). Geração de vapor. Florianópolis: Ed.UFSC.

BRITISH STANDARD - BS2790 (1986).

COSTA NETO, P.R. et al. (2000). Produção de biocombustível alternativo ao óleo diesel através da transesterificação de óleo de soja usado em frituras. Química Nova, São Paulo, v.23, n.4, p.531-537.

DELABROY, O. et al. (1998). Passive and active control of $\mathrm{NO}_{\mathrm{x}}$ in industrial burners. Experimental Thermal and Fluid Science, New York, v.16, n.1/2, p.64-75, Jan./Feb.

EL-MAHALLAWY, F.M. et al. (2003). Combustion and heat transfer characteristics in boilers with asymmetrical reversed flow flame tube. Experimental Thermal and Fluid Science, New York, v.27, n.4, p.417-430, Apr. 
FEITOSA, M.V. (2003). Desenvolvimento do motor de ignição por compressão alimentado por injeção direta de óleo diesel e por etanol pós-vaporizado no coletor de admissão. 217p. Tese (Doutorado) - Escola de Engenharia de São Carlos, Universidade de São Paulo, São Carlos.

GRIFFITHS, J.; BARNARD, J. (1996). Flame and combustion. New York: Chapman \& Hall.

GUNN, D.C. (1973). Heat transfer in the furnaces of shell type boilers. Proceedings Institution Mechanical Engineering, London, v.187, n.64, p.809-816.

GUNN, D.; HORTON, R. (1989). Industrial boilers. New York: Longman Scientific \& Technical.

INCROPERA, F.P.; DEWITT, D.P. (1992) Fundamentos de transferência de calor e de massa. Rio de Janeiro: Guanabara Koogan.

ITOKAZU, T. (2004). Biodiesel: uma alternativa para o diesel. Engenharia Automotiva e Aeroespacial, São Paulo, ano 4, n.19, p.6-9.

KUO, K.K. (1986). Principles of combustion. New York: John Wiley.

LORA, E.E.S. (2000). Prevenção e controle da poluição nos setores energéticos, industrial e de transporte. Brasília, DF: ANEEL. 
MARTINS, K.C.R. (2003). Estudo da aplicação de conversores catalíticos platina/paládio como auxiliar no processo de controle das emissões gasosas automotivas. 91p. Dissertação (Mestrado) - Escola de Engenharia de São Carlos, Universidade de São Paulo, São Carlos. 2003.

MEIRELLES, F.S. (2004). Biodiesel. Disponível

em:<http://www.faespsenar.com.br/faesp/economico/EstArtigos/biodiesel.PDF>. Acesso em: 13 set.

MINISTÉRIO DA INDÚSTRIA E DO COMÉRCIO (1985). Produção de combustíveis líquidos a partir de óleos vegetais. Brasília. (Série Documentos, 16).

MINISTÉRIO DAS MINAS E ENERGIA (2003). Disponível em:<http://www.mme.gov.br>. Acesso em: 25 nov.

MORAN, M.J.; SHAPIRO, H.N. (2002). Misturas reagentes e combustão. In:

Princípios de termodinâmica para engenharia. 4.ed. Rio de Janeiro: LTC. Cap.13, p.493-538.

OLADE - ORGANIZAÇÃO LATINO-AMERICANA DE ENERGIA (1995).

ÖZISIK, M.N. (1990). Transferência de calor: um texto básico. Rio de Janeiro: Guanabara Koogan. 
PAGLIUSO, J.D. (1984). Combustíveis e combustão. São Carlos: EESC/USP. Apostila.

RANGEL, L.P. (2003). Estudo do nitrogênio na combustão do gás natural. 197p. Tese (Doutorado) - Escola Politécnica, Universidade de São Paulo, São Paulo. 2003.

RHINE, J.M.; TUCKER, R.J. (1991). Modelling of gas-fired furnaces and boilers and other industrial heating processes. London: British Gas in Association With McGraw-Hill Book.

SANTOS, A.M. (2003). Termodinâmica. São Carlos: EESC/USP. Notas de Aula.

SANTOS, A. M.; SOUZA, G. R. (2004) Projeto e construção de uma câmara de combustão destinada à pesquisa na área de combustão e emissão gasosa de combustíveis derivados do petróleo. In: Congresso Nacional de Engenharia Mecânica, 3., Belém PA. Anais... Belém, UFPA.

SHER, E. (1998). Handbook of air pollution from internal combustion engines: pollutant formation and control. San Diego: Academic Press.

SHOKRY, S.A.; EL MORSI, A.K. (1991). Study of the distribution of heat absorption along the flame tube. Erdöl Erdgas Kohle, Hamburg, v.107, n.12, p.525-527, Dec.

SPIERS, H.M. (1952). Technical data on fuel. $5^{\text {th }}$ ed. London: British National Committee; World Power Conference. 
TASHTOUSH G.; AL-WIDYAN, M.I.; AL-SHYOUKH, A.O. (2003). Combustion performace and emissions of ethyl ester of a waste vegetable oil in a water-cooled furnace. Applied Thermal Engineering, Oxford, v.23, n.3, p.285-293, Feb.

U.S. CENSUS BUREAU (2004). International data base. Disponível em:<http://www.census.gov/>. Acesso em: 31 Aug.

WU, H.L. (1969). Comparison of the performance of natural gas and oil flames in a cylindrical furnace. Journal of the Institute of Fuel, London, v.42, n.343, p.316-322, Aug.

WYLEN, G.J.V.; SONNTAG, R.E.; BORGNAKKE, C. (2003). Reações químicas. In: Fundamentos da termodinâmica. Tradução de Euryale de Jesus Zerbini. São Paulo: Edgard Blücher. Cap.14, p.448-491. 